\title{
Open Science \\ NYÍLT TUDOMÁNY MAGYAR SZEMMEL
}


A Magyar Tudományos Akadémia Könyvtárának Közleményei Publicationes Bibliothecae Academiae Scientiarum Hungaricae

$45(120)$
UJ SOROZAT

SOROZATSZERKESZTő

GaÁlné Kalydy Dóra 


\section{Open Science \\ NYÍLT TUDOMÁNY MAGYAR SZEMMEL}

Magyar Tudományos Akadémia

KöNYVTÁr ÉS InFORMÁcIÓs KözPONT

BUDAPEST 2021 


\author{
Szerkesztette \\ GaÁlné Kalydy DóRA \\ Anyanyelvi lektor \\ MóNOK MÁRIA \\ Az irodalomjegyzékeket készítette \\ BudAI-KirÁLY TÍmEA \\ Tipográfia és tördelés \\ VAs ViKTória \\ ISBN 978-963-7451-73-7 \\ ISSN 0133-8862 \\ DOI 10.36820/MTAKIK.KOZL.2021.OpenS
}

Felelős kiadó: az MTA Könyvtár és Információs Központ főigazgatója

Nyomta és kötötte az Alföldi Nyomda Zrt., Debrecen

Felelős vezető: GYöRGy GÉzA vezérigazgató

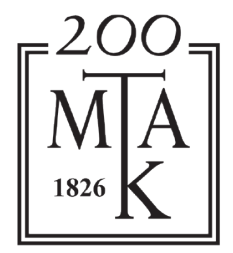

Megjelent a Nemzeti Kulturális Alap támogatásával

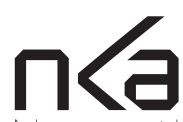

Nemzeti Kulturális Alap 


\section{TARTALOM}

\section{Monok István}

Cui bono, seu cui prodest?

Holl András

A tudományos szakkönyvtárak és a nyílt tudomány

(Open Science)

GaÁlnÉ Kalydy Dóra

A kiadókkal kötött Read and Publish szerződések, és a nyílt hozzáférésű publikálás hazai lehetőségei

Soós SÁndor, Kiss AnNA

Az „Open Access-előnyök" megnyilvánulása

a hazai tudásprodukcióban: bibliometriai hatásvizsgálat

61

\section{GaÁlné Kalydy Dóra}

A közösségi tudomány

\section{Tiberius Ignat}

What motivates us to develop the

Focus on Open Science series?

\section{Hoczopán Szabolcs, Molnár Tamás}

Az egyetemi könyvtárak szerepe a nyílt tudomány

mozgalom elterjesztésében

\section{Holl ANDrás}

Az MTA KIK gyakorlata a nyílt tudomány támogatásában $\quad 161$

A kötetben szereplő tanulmányok szerzői

A Magyar Tudományos Akadémia Könyvtárának

Közleményei, Új Sorozat közelmúltban megjelent kötetei 



\section{Cui bono, SEU CUI PRODEST?}

\section{MONOK IsTVÁN}

A címben megfogalmazott két kérdés jogi értelmezéséhez ragaszkodva biztosan tautológia, vagyis kétszer kérdezzük meg ugyanazt, hol Cicero, hol Seneca szavait használva. Ha azonban következetesen valljuk azt az alapelvet - amelyet a mindennapi gyakorlatban követésre méltónak tartok -, hogy nem minden legitim, ami legális, ám minden, ami legitim legalizálásra érdemes, akkor a kétféle kérdésfeltevés már indokolható. Magam számára a legitimitást tartom vezérfonalnak. A nyílt tudomány kérdéskörében jól megfogható a különbség a kétféleképpen (legitim/ legális) elfogadott cselekvések közt.

A nyílt hozzáférés apostolai abból az alapelvből indulnak ki, ami ajánlások szintjén még az Európai Unió hivatalosságának is része, nevesen: amely kutatási eredmény létrejöttét közpénzből finanszírozták, nem lehet nem nyílt hozzáféréssel közzétenni. Ezzel együtt teljesen magától értetődő, hogy a rögzített (szerzői, kiadói) jogokat nem sértheti ez a közzététel, és különösen is hangsúlyosan figyelni kell arra is, hogy a közzétevő magánvállalkozásoknak a nyilvánosságra hozatal nem okozhat erkölcsi, vagy pénzügyi veszteséget. De ha gondolkodásunkat a nyílt tudományról ebben az irányban indítjuk el, akkor alapvetően a legalitás oldalán maradva töprengünk. Számomra azonban fontosabb a legitim oldal.

A könyvtörténeti szakirodalomban az információs technológiák változásáról, fordulópontjairól többféle értelemzés olvasható. Mi volt a célja azoknak, akik kitalálták az exemplar és pecia rendszert a kéziratos könyvkiadásban? Mi Gutenbergnek akkor, amikor a mozgatható betűkkel történő szedés alapján való sokszorosítást kitalálta? A célok közt elsőként felsorolandó, hogy minél többen, minél könnyebben, minél több szöveghez jussanak hozzá. És mindig ott van az is, hogy a stationarius kapjon adókedvezményt, hiszen plusz kötelmeket vállalt (ami üzleti mozgásterét csökkenti), és az, hogy minden könyv 
megszületéséhez kell a mecénás is. Igen, a Gutenberg galaxis sikerét, azt, hogy az európai gondolkodás jelentôs újító kapacitáshoz jutott, egy vállalkozói csoport, a nyomdászok és alkalmazottjaik biztosították. A nyomdászok haszon-érdekeltsége (ez még nem profitszomj, pláne nem extraprofit-szomj) számos olyan újítást eredményezett, amitől az olvasás és a könyvhasználat hatékonyabbá vált (anyanyelvűség, képi illusztrációk, címlap, szövegtagolás, mutatók stb.).

Aztán a nyomdász mellett megjelent a kiadó, aztán különvált a kereskedői világ, és már a XVII. században tudunk olyan tudományos (orvosi) könyvkiadóról, amelynek tulajdonosáról többen állítják, hogy analfabéta volt. Aztán a fia már privilégiumokat szerzett, unokája és dédunokája pedig a legrangosabb kiadó lett Párizsban (Houry). Ezzel arra utalok, hogy a könyvkiadásban megjelent a befektető, aki nem könyvet akar kiadni, nem tudományos információkat akar másokkal megosztani, hanem elsődlegesen a meglévő pénzét kívánja szaporítani. Befektetésével azonban segítheti magát az eredeti célkitüzést is. Napjainkra a folyamat ott tart - remélem ezt fejlődésnek senki nem gondolja -, hogy a tudományos információ olyan áru, mint a kőolaj ráadásul éppen nagyobb hasznot is hoz az árusítása.

A nyílt hozzáférést tehát nehezített környezetben kell megvalósítani: jó az Open Access annak, aki éppen szabadon hozzáfér. Sajnos ugyanannak akkor, amikor a saját kutatási eredményéről van szó, már nem magától értetődően jó ugyanez. Ezzel az ellentmondással arra utalok, hogy nincsen a kérdésnek sem gordioszi, sem huszáros megoldása. Az egyik elfed valós ellentmondásokat, és hosszabb távon nem konfliktusmentes rendszer áll elő, a másik meg valószínűsíthetően komoly károkat is okozna a rendszerben a virtus megmutatásának értékét nem tagadva. Vagyis a tudományos információk szerzőitől a kereskedő cégekbe befektetőkig mindenkire szüksége van a rendszernek. Az nem állítható, hogy a teljes nyílt hozzáférés megvalósulásáig nem lesznek érdeksérelmek. 
A tudományos információk az egész világon túlnyomórészt közpénz felhasználásával keletkeznek. A közzétételük folyamatában megjelenő magánérdekek mentén sok a hozzáadott érték. A teljes Open Access elérésének folyamatában - magam azt gondolom - külön kell választani az elsődleges közlést attól, amikor az a hozzáadott értékkel együtt jelenik meg (ez utóbbi lehet egy másik, attraktívabb kereső, lehet ismeretterületek, dokumentum-együttesek összekapcsolása, mesterséges intelligencia alkalmazások stb., stb.). Biztosan lesz időszak, amikor csak előbbi lesz elérhető mindenki számára állampolgári jogon, és a hozzáadott értéket kell megfizetni. Maga a köz persze eldöntheti, hogy ez utóbbi finanszírozásából milyen mértékben veszi ki a részét azért, hogy a - mondjuk így - passzív szabad elérés lehetőségét kiegészíti az attraktív elérések szabadságának megteremtésével. 



\section{A TUdOMÁNYOS SZAKKÖNYVTÁRAK ÉS A NYÍLT TUdomány (Open Science)}

\section{Holl ANDRÁs}

A nyîlt tudomány a kutatás és a tudományos kommunikáció különböző, nagyobb átláthatóságra törekvő módszertani területeit átfogó gyűjtőfogalom. Mindenképpen ennek körébe tartozik a nyílt hozzáférés (Open Access) és a kutatási adatok nyílt kezelése (Open Research Data). Ez utóbbinál újabban nem a nyílt, hanem a FAIR jelzőt alkalmazzák. A nyílt kutatási munkafolyamatok kevésbé fejlettek, a nyílt bírálati eljárások (Open Peer Review) ugyanakkor gyorsan fejlődnek. A nyílt tudomány összekapcsolódott néhány, eredetileg különálló területtel is, mint a nyílt forráskódú szoftverek (a tudomány műveléséhez kapcsolódó részük), a nyílt oktatási lehetőségek, vagy a közösségi tudomány (Citizen Science).

Az Open Science taxonómiája a FOSTER ${ }^{1}$ projekt szerint:

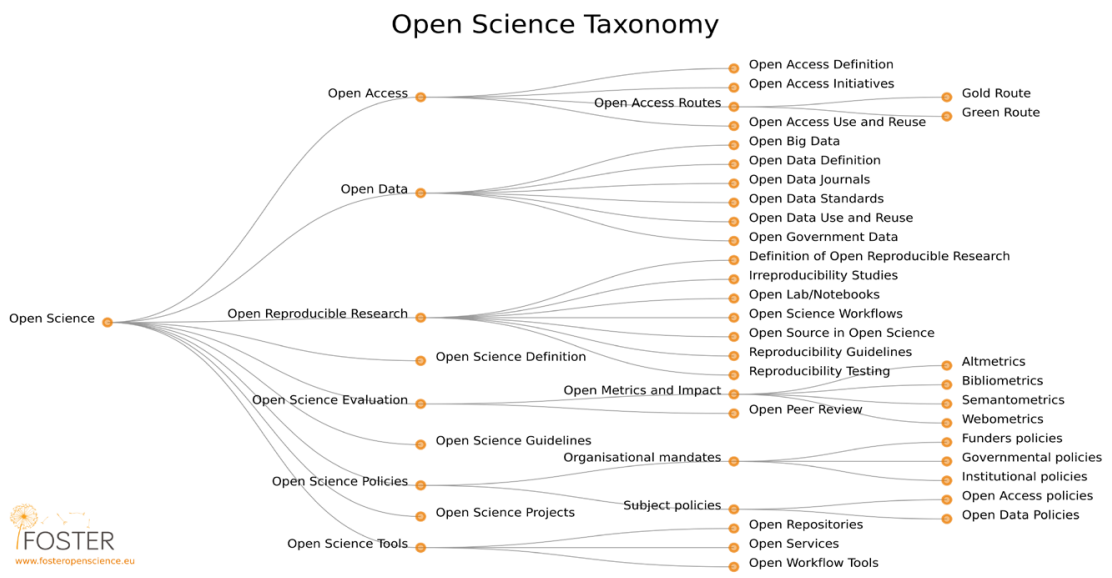

1 https://www.fosteropenscience.eu/ (utolsó megtekintés: 2021. 09. 23.) 
A nyílt tudományra szükség van, mert

- az exponenciálisan bővülő tudomány menedzselhetőségét, finanszírozhatóságát fenn kell tartani;

- szükség van a tudomány iránti állampolgári bizalom erősítésére;

- biztosítani kell a tudományos kutatók utánpótlását;

- csökkenteni kell a fejlődő országok lemaradását;

- növelni kell a tudomány társadalmi és üzleti hasznosulását;

- növelni kell a hatásfokot (egységnyi ráfordításból több eredményt kell elérni);

- és legfőképpen jobb minőségbiztosításra van szükség: növelni kell a reprodukálhatóságot.

Másként fogalmazva: az alapvető célok a kutatási eredmények verifikálhatóságának erősítése, a kutatási eredmények újrafelhasználhatóságának bővítése és a tudomány transzparenciájának növelése. A tudományos alapkutatás célja, hogy az eredményeit alkalmazzák mind további kutatásokban, mind a gyakorlatban. A kutatók karrierjének alapvető értékelése munkájuk felhasználásán, idézettségén alapul. Nem célszerű a kutatási eredmények terjesztésének útjába akadályokat állítani.

A tudományos szakkönyvtárak a nyílt tudomány elsőnek kialakult területén, a nyílt hozzáféréssel foglalkoznak leginkább. A Budapest Open Access Initiative (BOAI) ${ }^{2}$ fogalmazta meg a nyílt hozzáférés két lehetséges útját - ezek közül a repozitóriumi (zöld) út esetében a könyvtárak lehettek a szolgáltatások megvalósítói (noha az 1990-es években, még az OA mozgalom előtt indult arXiv kutatói kezdeményezés volt). A könyvtárak oldaláról jelentkezett a legerősebb motiváció is: a folyóirat-előfizetések egekbe szökő költségei. (Azt még nem lehetett látni akkoriban, hogy az APC-k kezelése is könyvtári feladat lesz.)

A nyílt tudomány jelenleg inkább egy célkitűzés, egy elképzelés, mint

2 https://www.budapestopenaccessinitiative.org/ (utolsó megtekintés: 2021. 09. 23.) 
mindennapi gyakorlat. A nyílt hozzáférés is erősen változik, fejlődik, pedig ez a részterület már majdnem két évtizedes múltra tekint vissza (amennyiben a BOAI-tól számítjuk). A nyílt kutatási adatok tekintetében és más területeken a nyílt tudomány éppen egy „bootstrap” fázisban van; a kutatói közösség saját gyakorlatát kell magasabb szintre emelnie anélkül, hogy ennek szilárd támaszai lennének (pl. kialakult szabványok, módszerek). A nyílt tudomány módszereit, eszközeit és szabványait „menetből” kell kifejleszteni.

Akkor lehet sikeres a nyílt tudomány, ha alapelvei és gyakorlata szervesen integrálódnak a kutatási ciklusba. Meg kell ebben a folyamatban találni a könyvtárak szerepét is - mint ahogy a korábbi paradigmákra alapozott kutatási ciklus esetében is történt.

A nyílt tudomány alapvetően digitális környezetben, informatikai eszközök használatával végezhető. (Egyfelől mára egyre inkább digitalizálódik az emberi tevékenység minden vetülete, másfelől a hozzáférés és az újra-felhasználás lehetőségei a digitális technikák alkalmazásával új szintre léptek. Kulcstechnológiái közül az egyik az állandó azonosítók (persistent identifiers, PID) ${ }^{3}$ használata. Ezek az azonosítók végigkísérik a digitális objektumok életét, és alkalmasak arra, hogy segítségükkel az emberi vagy gépi felhasználó eljuthasson az objektumhoz. Sokféle állandó azonosító létezik, a későbbiekben azonban csak a legelterjedtebbel, a Digital Object Identifier-rel (DOI) foglalkozunk.

A nyílt tudomány nem működtethető anyagi háttér hiányában. A szolgáltatásokból hasznot húzó közösségnek támogatnia kell a kiszolgáló infrastruktúrák működtetését - a támogatások szervezését végzi a Global Sustainability Coalition for Open Science Services (SCOSS).

3 https://www.dpconline.org/handbook/technical-solutions-and-tools/ persistent-identifiers (utolsó megtekintés: 2021. 09. 23.) 


\section{A tudomÁnYos SZAKKöNYVTÁrAK ÉS A NYÍLT HOZZÁFÉRÉS (Open Access)}

Nemigen akad olyan nézete a nyílt hozzáférésnek, ahol a könyvtárak ne lennének érdekeltek. Kezdve a kutatók, olvasók tájékoztatásától, képzésétől a repozitóriumok működtetésén és a publikálási díjak (APC) kezelésén át egészen a tudományos könyv- és folyóirat-kiadásig.

A nyílt hozzáférés alapjait illetően Sauber (2012) alapművét ajánljuk tájékozódásra, a könyvtári feladatokat és problémákat pedig Holl (2018a) tárgyalja részletesen.

\section{1.) TÁjÉKOZTATÁS, KÉPZÉS}

A szakkönyvtárak olvasószolgálatosainak át kell alakítaniuk működésüket, mivel az olvasók (kutatók, oktatók, egyetemi hallgatók) által igényelt szakirodalom egyre nagyobb mértékben elérhető nyílt forrásokból. Nem sok beavatkozást igényel részükről az a tény, hogy az általuk előfizetett indexelő rendszerekben (WoS, Scopus) a szabadon olvasható tartalmak száma nő. Fontosabb változás, hogy ezen a piacon új szereplők tűntek fel (Dimensions, Lens, Microsoft Academic stb.). Megjelentek azok az eszközök, amelyek a böngészőkbe telepítve megtalálják a fizetôs tartalmak repozitóriumokban szabadon elérhető kópiáit (Unpaywall). Ilyen technológiát használ a cikkek DOI alapon való keresésére az EISZ COMPASS is. És megjelentek az „akadémiai” közösség által fenntartott, szabadon használható kereső-aggregátorok, mint a Jisc CORE és a BASE. (Hazai közös kereső az MTA KIK és a SZTAKI által működtetett http://oaikereso.sztaki.hu/.)

Sok könyvtár kínál olvasóinak egyablakos keresőt. Itt fontos szempont, hogy a kereső indexelje a szabad tartalmakat - elsősorban a saját repozitórium tartalmait.

További, a repozitórium üzemeltetéssel összefüggő feladat a zárolt dokumentumok helyben olvasásának technikai és jogi feltételeit megteremteni. 
Hasonlóan fontos az egyetemi hallgatók, oktatók és kutatók számára a nyílt hozzáféréssel is foglalkozó képzés. Része a tájékoztatási feladatoknak a nyílt hozzáférés élősködőinek (parazita vagy predátor folyóiratok, Holl 2020b) ismertetése, vagy a nyilvántartások nyomon követése.

\section{2.) RePOZitóRIUMOK}

$\mathrm{Az}$ Open Archives Initiative nyomán létrejött, PMH protokollt alkalmazó repozitóriumok üzemeltetése a tudományos szakkönyvtárak alapvető feladatává vált. Bár más digitális könyvtári platformok is elképzelhetők, jelenleg semmilyen IKR, semmilyen más CMS rendszer nem tudja azokat a funkciókat megvalósítani, ami egy repozitóriumi szoftvertől elvárt:

- OAI-PMH protokoll támogatás

- SWORD protokoll támogatás

- flexibilis felhasználói feltöltési lehetőség

- embargó alkalmazásának lehetősége

- széles felhasználói-üzemeltetői közösség.

Csak akkor tudják jól teljesíteni feladataikat a repozitóriumok, ha a könyvtár gondoskodik bekapcsolásukról a különböző hálózatokba (szolgáltatólisták [registry], aggregátorok) - ennek gyakorta feltétele tanúsítványok beszerzése.

Azon túl, hogy az aktív kutatók publikációihoz való nyílt hozzáférést megvalósítják, az intézményi digitalizálási programok eredményeinek tárolására is alkalmasak. Amennyiben a könyvtár DOI azonosítók szolgáltatásával is foglalkozik, a repozitórium funkcionálhat elsődleges tartalomszolgáltatóként (pl. saját webes szolgáltatással nem rendelkező, vagy a könyvtár által kiadott publikációknak), vagy másodlagos, biztonsági archívumként. 
A szoftverüzemeltetésen túl a repozitórium-üzemeltetés további állandó feladatokat is jelent a könyvtáraknak. Fontos a gyarapítási folyamatban a könyvtárosi kontroll: ügyelni kell a feltöltött állományok minőségére, a megfelelő metaadatokra, a kiadói jogokra stb. A repozitóriumokat össze kell kapcsolni különböző, a könyvtár által működtetett (vagy külső) rendszerekkel: IKR, egyablakos kereső, CRIS rendszer (Magyarországon az MTMT).

A repozitóriumnak a könyvtár egyik alapvető szerves részegységének kell lennie, szerepelnie kell az SZMSZ-ben, személyi és költségvetési erőforrásokkal kell rendelkeznie. Ezt elősegíti a repozitórium minősítése is - hazai lehetőség erre az MTMT repozitórium-minősítő bizottsága által adott tanúsítvány. Egyúttal a repozitóriumnak illeszkednie kell az országos és nemzetközi hálózatokba. Ajánlatos a HUNOR tagság az üzemeltetőnek, technikailag be kell jegyezni a repozitóriumot különböző lajstromokba - enélkül, illetve minősítések híján nem tudja hatékonyan láthatóvá tenni a tartalmait.

A repozitórium lehet az eszköz a különböző intézményi vagy projektdokumentációk megőrzésére és közzétételére. A szürke irodalom körébe tartoznak a disszertációk is, ezek közül a PhD disszertációkról a felsőoktatási törvény is rendelkezik. (Az MTA doktori disszertációi 2010-től kötelezően, a korábbi doktori és kandidátusi disszertációk igény és engedély esetén a REAL-d-be kerülnek, egyes szerződött, jellemzően kisebb egyetemek $\mathrm{PhD}$ dolgozatai pedig megállapodás alapján a REAL-PhD-be.)

A repozitóriumok hosszútávú megőrzési feladatának teljesítéséhez elsősorban az üzemeltető intézménynek kell megteremtenie a feltételeket. Ezek közé sorolhatjuk a stabilitást (szabályozás, költségvetés, munkaerő), a technikai biztonságot (mentés, monitorozás, behatolásvédelem stb.). Mindazonáltal előfordulhat, hogy a repozitóriumot működtető intézmény vagy maga a repozitórium megszűnik. Erre a helyzetre ad biztonságot a tartalmak megosztása és a végrendelet ( $k i$ veszi át a tartalomszolgáltatást megszűnés esetén). Ez 
utóbbi persze akkor működik biztonságosan, ha a tartalmak lemásolása (sötét archívumként) folyamatos.

\section{3.) KÖZLÉSI dÍJAK (APC) MENEDZSELÉSE}

A tudományos szakkönyvtárak feladata az elektronikus tartalmak (pl. folyóiratok, e-könyvek) előfizetése. Az előfizetések kezelésében mára fontos szempont lett az OA és az APC kérdése. Az előfizetési döntések meghozatalára kínál segítséget a hazai szakkönyvtáraknak a COMPASS+.

Az intézmény kutatói több különböző csatornán keresztül fizethetnek közlési díjakat (Article Processing Charge, APC). Egyrészt fontos könyvtári feladat a Read and Publish szerződésekben szereplő lehetőségekről való tájékoztatás a kutatóknak, másfelől meg kell kísérelniük a szerződéseken kívül történt APC kifizetések nyilvántartását.

\section{4.) RÉSZVÉTEL A FOLYÓIRAT- ÉS KÖNYVKIADÁSBAN}

A tudományos szakkönyvtárak külföldön (pl. az UCL) és Magyarországon egyaránt (SZTE, DE, MTA KIK stb.) folytatnak kiadói tevékenységet is. Ehhez gyakorta használják az OJS platformot (esetleg az OCS-t vagy OMP-t). Előfordul az is (pl. MTA KIK), hogy szoftverplatformot biztosítanak más kiadók által kiadott folyóiratoknak. A könyvtár érdekeltsége ez esetben az lehet, hogy a saját platformon vendégül látott tartalmak archiválásra kerülhetnek a repozitóriumban, kereshetők a könyvtári egyablakos keresőben, illetve a könyvtári DOI szolgáltatás is kapcsolatot jelenthet.

A saját kiadású vagy vendég folyóiratok megfelelő láthatósága, használhatósága érdekében regisztrálni kell a kiadói archiválási szabályokat a SHERPA RoMEO ${ }^{4}$-ba, minősíttetni a folyóiratot itthon, illetve - a DOAJ által - biztosítani, hogy bekerüljön a hazai közös keresőbe.

4 https://v2.sherpa.ac.uk/romeo/ (utolsó megtekintés: 2021. 09. 23.) 


\section{5.) DOI Azonosítók}

Azon túl, hogy a könyvtárak a repozitóriumaikban elhelyezett és nyilvánossá tett cikkek kiadói DOI-jait rögzítik (és megfelelő beállítások esetén ezáltal láthatóvá teszik az oaDOI adatbázison keresztül), saját maguk is segíthetik a tudományos kommunikációt DOI iroda működtetésével. A kutatási adatokhoz is használt DataCite DOI-knak lehet szerepük a szürke irodalom esetében, de általánosságban a publikációk számára a CrossRef DOI-k több előnyt biztosítanak.

A folyóiratok kiadói ma Magyarországon többnyire már tisztában vannak azzal, hogy a DOI fontos, azt azonban gyakorta nem tudják, mit kell elvégezniük ahhoz, hogy a DOI-k funkciójukat betölthessék.

6.) INTÉZMÉNYI NYÍLT HOZZÁFÉRÉSI POLITIKA KIALAKÍTÁSA ÉS MONITOROZÁSA

Az intézményi nyílt hozzáférés szabályozásának kialakításában is szerepe van a könyvtáraknak - mint végrehajtóknak, monitorozóknak és szakismeretekkel rendelkezőknek. Az intézményi nyílt hozzáférésszabályozás (Open Access Mandate) fontos eleme a gondolkodás és gyakorlat alakításának. A hatékony rendelkezés előír, intézkedik a feltételek megteremtéséről, a kivételekről, az ellenőrzésről és a retorziókról, ill. jutalmazásról. Igen hatékony lehet az a gyakorlat, hogy a teljesítmények elszámolásához csak az intézményi repozitóriumban elhelyezett munkákat veszik figyelembe. Ugyanilyen erős megoldás a CRIS rendszerek (pl. MTMT) alkalmazása, ahol nemcsak a helyi, zöld utas megoldásokat lehet figyelembe venni.

A különböző szabályozásokat listázó szolgáltatások a ROARMAP5 és a SHERPA Juliet ${ }^{6}$.

5 https://roarmap.eprints.org/ (utolsó megtekintés: 2021. 09. 23.)

6 https://v2.sherpa.ac.uk/juliet/ (utolsó megtekintés: 2021. 09. 23.) 
Nemcsak a saját, hanem a finanszírozói és egyéb „külső” OA rendelkezésekről is tájékoztatnia kell a kutatókat a könyvtárosoknak, valamint a kiadói politikákról és az ezek ellenőrzésére használható eszközökről (pl. SHERPA RoMEO) is.

Bekerül a könyvtári feladatok közé az OA statisztikák készítése. Ennek egyik eszközét az MTMT adja.

7.) Folyóiratok ÉS KÖNYVEK előfizetése

Az előfizetési folyamatban - történjen az az EISZ-en keresztül, vagy egyénileg - egyre nagyobb szerepe lesz annak felmérésének, hogy az előfizetendő adatbázisban milyen hányadban szerepelnek szabadon hozzáférhető tartalmak, illetve az előfizetési szerződések tartalmaznak-e OA közlési lehetőséget.

A döntéshozatalban nyújtanak segítséget az EISZ COMPASS és COMPASS+ szolgáltatásai. A COMPASS+ segítségével intézményi OA adat is megállapítható, arra a folyóirat-körre, amit a Dimensions adatbázis lefed. Jelentős könyvtárosi feladat a COMPASS+ adatokkal való feltöltése.

Általában elmondható, hogy a tudományos szakirodalom - a számítás módjától függően, ilyen vagy olyan módon - fele-harmada szabadon hozzáférhető (Holl, 2020c, Archambault et al., 2013). Ezt az arányt két évtized alatt sikerült elérni. Remélhetően a jövőben gyorsabban bővül majd a szabadon elérhető tudományos tartalmak köre. A könyvtáraknak alkalmazkodniuk kell az új realitásokhoz. 


\section{Nyílt kutatási adatok (Open Research Data).}

\section{A TUDOMÁNYOS SZAKKÖNYVTÁRAK ÉS A KUTATÁSI ADATOK KEZELÉSE}

Manapság a nyílt tudomány koncepciója egyre nagyobb figyelmet kap Magyarországon is. A hagyományosabb nyílt hozzáférés mellett ebben megjelenik a kutatási adatok kezelésének témaköre is. Jelen tanulmányunkban azt vizsgáljuk, lehet-e szerepe a tudományos szakkönyvtáraknak a kutatási adatok kezelésében, és ha lehet, mi az.

Először definiáljuk a szabadon hozzáférhetővé tehető kutatási adatok fogalmát! A kutatási adatok - azok a tények, amelyeket a vizsgálatok során felszínre hoznak, kiválogatnak, összegyüjtenek, modelleznek a kutatók - a tudomány nyersanyagai. Míg korábban ezek az adatok naplóbejegyzések formájában, papíron, fénykép, videó vagy hangfelvételekként, összegyüjtött kőzetminták, régészeti leletek, mikroszkópi vizsgálathoz preparált metszetek stb. formájában léteztek, manapság egyre inkább eleve digitális formában születnek, vagy utólagosan digitalizálásra kerülnek. A fejlődő technológia olyan kutatási objektumokról is jó minőségü digitális másolatokat tud készíteni, amelyeket korábban csak kézbe véve, emberi szemmel lehetett megfigyelni. A materiális kutatási adatokhoz lehet ugyan hozzáférést biztosítani, de a kutatási adatokhoz való nyílt hozzáférést csak digitális formában lehet kiteljesíteni. Míg a különböző materiális adatok tárolása, feldolgozása jellegüktől függő (üveglemezre készült fotográfia, kövület, kotta stb.), a digitális adatok tárolása és feldolgozása sokkal hasonlóbb eljárásokat kíván - még ha ezek az eljárások, technikák sokrétúbbek is, mint mondjuk a digitalizált publikációk esetében szükségesek. Mons (2018) definíciója szerint a kutatási adat „egy vagy több digitális objektum együttese, amely a kutatás során keletkezett, vagy a kutatásban felhasználásra kerül".

A könyvtárak nem adattárak; bár az információtechnológiát hamar befogadták, nem rendelkeznek általános szakértelemmel ezen a területen. Nincsen kapacitásuk nagy mennyiségü adat tárolására, a feldolgozást nem is említve. Nem szakértői az adatvizualizációnak, és 
általában nem foglalkoztatnak a különböző tudományterületeken jártas szakembereket (a különféle bölcsészektől eltekintve, akikkel gyakran találkozhatunk a könyvtárosok között). Milyen érv szól amellett, hogy a könyvtárosoknak kutatási adatok kezelésével kellene foglalkozniuk?

Először is, a könyvtárak memória-intézmények, alapfeladatuk, hogy információkat kezeljenek, tegyenek hozzáférhetővé hosszú távon. Lehet, hogy a kutatást végző intézménynek van adattára (fotótára, tervtára, leletraktára stb.) vagy levéltára, de gyakorta a könyvtár az egyetlen megőrző szervezeti egység. Akutatási adatok nem maradhatnak a hosszabb-rövidebb időtávokon létező kutatócsoportoknál, fenntartásukra nem alkalmasak a projektköltségvetések. Sok esetben nem marad más, mint a könyvtár. A könyvtáros-kultúra része a kutatók kiszolgálása, a könyvtárosoknak nagy gyakorlata van a metaadatok terén, használnak (esetenként ki is adnak) állandó azonosítókat, üzemeltetnek, használnak, oktatnak keresőrendszereket.

A kutatási adatok kezelésében három csoportnak is szerepe van: az informatikusoknak, a könyvtárosoknak és a kutatóknak maguknak. De mint intézmény, a könyvtár (vagy Könyvtár és Információs Központ) lehet a megfelelő szervezeti egység. Amennyiben az intézmény elég nagy ahhoz, hogy önálló adattárat működtessen, akkor is gondoskodni kell a könyvtár bekapcsolásáról (az informatikai részleg mellett).

A kutatási adatok jelentős részét nagy projektek (Derek de Solla Pricenál ez a Big Science) hozzák létre. Ezekben az esetekben a költségvetés lehetővé teszi a megfelelő (manapság a FAIR elveket szokás emlegetni) adatkezelést. A nagy projektek adatai specializált adatbázisokba kerülnek. Viszont ott vannak a kis projektek (Little Science), egyedi kutatók, kis csoportok, hagyományosan szerényen finanszírozott területek (pl. bölcsészettudományok) - itt összességében szintén sok kutatási adat keletkezik, és ezek az adatok is értékesek! Ez a kutatási adatok eloszlásának hosszan elhúzódó vége, a „long tail”. Ezeknek az adatoknak a kezelésében különösen fontos szerepe lehet a könyvtáraknak. 
Az egyik ok a szórvány adatok könyvtári kezelésére az, hogy a tárolt információk előhozásának fontos alapelve, hogy az információt valamiféle hálózatban, kontextusban kell elhelyezni. Ilyen hálózat (valójában többszörös hálózat) a bibliográfiai háló. A publikációs csomópontokat a hivatkozások élei kötik össze,-a publikációkat készítő kutatókat pedig társzerzőség alapján lehet összekötni. Az egyes kutatási adatcsomagok is köthetők a rájuk épülő publikációkhoz, az őket létrehozó kutatókhoz, intézményekhez, finanszírozó projektekhez. A tudományos közlemények hálózata alkalmas lehet a kutatási adatok felfedezésére is. A könyvtárak és könyvtári jellegű szervezetek jól kezelik ezeket a hálózatokat.

A fentiek alapján állíthatjuk, hogy a könyvtárak alkalmasak az olyan adatok kezelésére, amelyek szorosan publikációkhoz kapcsolódnak (egy adatsor és az elemzéséből született cikk - de lehetnek bonyolultabb, több cikket vagy több adatsort összekapcsoló relációk is). Olyan adatokat tudnak kezelni, amelyek nem túl nagy terjedelműek, egyszerű (pl. szöveg alapú, mint a CSV, XML, JSON) formátumokban tárolhatók. Nem tudnak kezelni viszont nagy terjedelmü vagy nagyszámú adatállományt, bonyolult formátumokban, amelyek megjelenítése, kezelése speciális szoftvereket igényel. Az adatállományok elhelyezésének eszköze lehet az intézményi repozitórium, ahol az adatok a közlemény mellé helyezhetők. A könyvtárakban történő adatkezelés inkább azokban az esetekben javallott, ahol az adatok szabadon hozzáférhetővé tehetők - a zárt adatkezelés, a speciális jogosítványokat igénylő hozzáférés biztosítása nem a könyvtárakra van szabva.

A kutatási adatok kezelése olyan terület, történjen akármilyen szervezeti egységben is, amelyet csak könyvtárosok, informatikai szakemberek és a kutatók együttműködésével lehet végezni (Holl, 2018b). $\mathrm{Az}$ adatkezeléshez előnyös külön szakembereket alkalmazni; ők az adatgazdászok (data steward). Könyvtári mundérban az egyes kutatási területek adatkezelési gyakorlatához értő könyvtári szakemberek, a kutatói közösségekbe beágyazott könyvtárosok végezhetnek adatgazdászi feladatokat. 
Hatékony könyvtári közreműködés (és általában hatékony kutatási adatkezelés) csak úgy valósítható meg, ha a módszerek, szabványok, technológiák, a munkamegosztás beépül a kutatási ciklusba, illetve ezen belül a kutatási adatok életciklusába.

Többnyire a kutatási adatok kezelésébe való bekapcsolódás azt jelenti a könyvtárak számára, hogy új technológiákat kell bevezetniük. De a könyvtárosok is megtaníthatják a kutatókat és az informatikusokat régi technológiák használatára, jól bevált paradigmák alkalmazására. A könyv (beleértve a digitális médiát, pl. a PDF-et is) könnyen készíthető, olvasható, archiválható. Egy bonyolult adathalmazból is érdemes biztonsági célzattal digitális könyvet készíteni. Sőt, talán még kinyomtatni is érdemes néhány példányban!



A kutatási adatok kezelési gyakorlatát illetően ajánljuk Mons (2018) könyvét, illetve a könyvtárak lehetséges szerepéről a LIBER által szervezett 2015-ös workshop összefoglalóját ${ }^{7}$, valamint a szervezet

7 https://libereurope.eu/wp-content/uploads/2020/11/LIBER2015_RDM_ workshop_report_2015-1.pdf (utolsó megtekintés: 2021. 09. 23.) 
által megfogalmazott tíz ajánlást ${ }^{8}$. Az egyik első hazai kutatási adatrepozitóriumról Micsik és Gárdos (2014) számol be.

\section{KÖNYVTÁRI SZEREPEK AZ ADATKEZELÉSBEN}

\section{1.) TANÁCSADÁS}

Az olvasószolgálat hagyományos könyvtári szerep. A könyvtárosok az általuk ismert, előfizetett vagy üzemeltetett keresőszolgáltatásokon keresztül (bibliográfiai háló!) segíthetnek a kutatási adatok lokalizálásában, vagy tanácsot adhatnak a láthatóság növelésére.

Magyarországon - de számos más országban is - a könyvtárosok a legaktívabb résztvevők az Open Science mozgalomban. A hazai, kutatási adatkezeléssel foglalkozó rendezvények résztvevőinek többsége könyvtáros (egyfelől szomorú, hogy nem sikerül az ismereteket hatékonyan eljuttatni a kutatókhoz, másfelől viszont rámutat, hol lehet szakértőket találni).

\section{2.) A publikációs Kapcsolat}

Említettük a bibliográfiai hálózatok szerepét. Itt a tudományos szakkönyvtáraknak több feladatuk is lehet.

- Kutatási adatok keresése (l. fentebb). A könyvtárosok segíthetnek a kutatóknak adatokat keresni témakör, kulcsszó, szerző, intézmény alapon, az általuk előfizetett vagy használt kereső rendszerekben (beleértve a discovery service-eket is).

- Tanácsadás a szerzőknek kutatási adatok láthatóbbá tételéhez, a fenti rendszereken keresztül. Itt fontos elem, hogy a kutatási adatok DOI azonosítói legyenek feltüntetve a közleményben, mind a saját

8 https://ibereurope.eu/wp-content/uploads/2020/09/The-research-datagroup-2012-v7-final.pdf (utolsó megtekintés: 2021. 09. 23.) 
adatoké, mind a felhasznált idegen vagy publikus adatoké; megfelelő kulcsszavak elhelyezése.

- A könyvtár által kezelt (pl. repozitóriumban tárolt) kutatási adatok láthatóságának növelése. Itt arról lehet gondoskodni, hogy a könyvtár által biztosított egyablakos kereső (discovery service) arassa a saját adatrepozitóriumot, ill. átvegye a publikációs repozitóriumból az ott tárolt adatállományokra vonatkozó metaadatokat. Ezen túl meg lehet vizsgálni az egyéb, publikációs repozitóriumok felé való, kutatási adatokra vonatkozó adatátadást is (pl. az OIA-PMH kimenet megfelelő konfigurálásával).

\section{3.) Segítség a metaAdatok megadásában}

A kutatási adatok leíró metaadatai (discovery level) azonosak vagy hasonlóak a publikációkéval. Ezek megadásában, kezelésében a könyvtárosoknak nagy tapasztalata van. Ezeknek a metadatoknak a rögzítésére a Dublin Core séma alkalmas. Leíró jellegü adatok származtathatók az adatokhoz tartozó cikk leíró adataiból, jobb híján ezekre támaszkodhatnak a könyvtárosok, illetve ezek az adatok többnyire kiolvashatóak a cikkből is.

A szakmai metaadatok megadása nem könyvtári kompetencia. A könyvtárosok az adott tudományterületen rendelkezésre álló, regisztrált ontológiák, szótárak felderítésében tudnak segíteni, illetve ellenőrizhetik azt, hogy a metaadatok között van-e ilyenekre utalás, és az létező forrásra mutat-e.

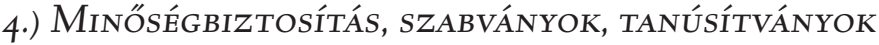

A kutatók - különösen az egyedül, vagy legalábbis nem nagy, nemzetközi együttműködésekben dolgozó kutatók segítségre szorulhatnak abban, hogy adataik megfelelők legyenek a FAIR szempontrendszernek. A tanácsadáson túllépve a könyvtárosok bekapcsolódhatnak az adatmenedzselésbe, a folyamat résztvevőivé válhatnak. Ez lehet a kutatási folyamatba beágyazott könyvtárosí, 
szakterületi adatgazdászi feladat, de történhet abban a fázisban is, amikor a könyvtár által üzemeltetett repozitóriumban elhelyezett adatcsomagok ellenőrzését végzik, a könyvtár által működtetett folyóiratplatform vagy kiadott folyóirat kapcsolt kutatási adatait ellenőrzik, és akkor is, ha a könyvtár szolgáltat DOI azonosítókat az adatok számára.

Az adatokra (és a hozzájuk tartozó metaadatokra) vonatkozó, a FAIR szempontrendszert kibontó elvárásokról az EOSC FAIR WG Metrics and Certificates Task Force anyagaiból, és az anyag által feldolgozott (és hivatkozott) forrásokból lehet többet megtudni. Az EOSC és az RDA különböző munkacsoportjai és projektjei fejlesztenek eszközöket, amelyeket az adatminőség vizsgálatára lehet használni.

$\mathrm{Az}$ adatminőség ellenőrzésének véleményünk szerint a legfontosabb eszköze a szakterületről kikerülő lektor/bíráló véleménye, a peer review. Az ideális folyamat az, hogy ha a közlésre benyújtott cikket bíráló független szakértőkhöz eljutnak azok az adatok is, amelyekre a kutatás alapul. Ez a cikk bírálata szempontjából is előnyös, és az adatokéból is. A cikk gyakorta a legjobb leírást nyújtja az adatokról, a kutatás motivációjától az adatok részletes, a keletkezés (megfigyelés, kísérlet, szimuláció) körülményeinek leírásán keresztül a minőség megítéléséig minden szempontból.

Ha a kutatók tanácsért fordulnak a könyvtárhoz, az elhelyezésre ajánlott repozitóriumoknál szempont a minőségi tanúsítványok megléte. De ennél is fontosabb, hogy a könyvtár által működtetett repozitóriumok, kiadott folyóiratok tanúsítvánnyal rendelkezzenek. Ezeken a területeken lehetséges hazai, az MTMT Repozitóriumminősítő bizottságával minősíttetni a repozitóriumot. A minősítés általában idő (és néha anyagi) befektetést igényel. A hazai rendszer követelményei általában valamivel alacsonyabbak a nemzetközieknél, a hazai minősítésre lehet a nemzetközi minősítés előszobájaként tekinteni. Open Access folyóiratoknál a nemzetközi minősítés a DOAJ által történhet, repozitóriumoknál a még reálisan megszerezhető tanúsítvány a CoreTrustSeal. 


\section{5.) Technikai KéRdések}

Ez az a terület, ahol a könyvtárak legkevésbé járatosak. Formátumok, tömörítés/csomagolás, az adatok változatlanságát biztosító eszközök (checksum, CRC stb.), tárhely, jogosítványok, megjelenítés, feldolgozás - mind-mind fontos, a könyvtárak által nehezen kezelhető kérdések. Ajánlatos a könyvtáraknak olyan „gyüjtőkört” kialakítani, ahol ezek a legkevésbé jelentenek akadályt. Nem tartozik a könyvtárak kompetenciájába az adatok feldolgozása sem - az igen nagy adattömegeknél nem az adatokat kell elvinni a feldolgozás helyére, hanem a felhasználó algoritmusait, programjait kell az archívumban lefuttatni.

Jó példa (az MTA KIK gyakorlatából), amikor egy pszichológus kért segítséget adatai elhelyezéséhez, ami nélkül nem közölte volna a cikkét egy nemzetközi folyóirat. A publikációs repozitóriumba kerültek a CSV formátumban lévő adatok (kérdőívek kiértékelése), a cikk valamilyen változata mellé. Néhány kisméretű fájl, szöveges formátum, melynek megjelenítéséhez nem kell külön szoftver, amely bizonyos mértékig ellenőrizhető „ránézéssel”. Az adatok felderíthetőségét a cikk felderíthetősége biztosítja.

Ha a könyvtárak ennél bonyolultabb feladatra vállalkoznak, fontos, hogy megfelelő (szabványos, elterjedt, nyílt, szabad szoftverrel olvasható és írható) formátumokat követeljenek meg, és a metaadatok között biztosítsák a technikai információk elhelyezését: pl. formátum (verzió), szükséges szoftverek felsorolása, méret, fájlok száma, ellenőrző összegek.

\section{6.) JoGI KÉRDÉSEK, FELHASZNÁLÁSI LICENC}

Szükséges az adatok elhelyezőjét nyilatkoztatni arról, hogy az adatok elhelyezésének, nyilvánosságra hozatalának nincs akadálya, nem merülnek fel etikai vagy személyiségi jogi problémák. 
Ugyancsak fontos kritérium a megfelelő felhasználási licenc alkalmazása. Ez lehet az elterjedt Creative Commons licenc-család valamelyik tagja, szoftvereknél valamilyen elterjedt szoftverlicenc (GNU, Apache stb.).

\section{7.) SZÜRKE IRODALOM}

Ez az egyik terület, ahol a könyvtárak szerepe a leghatározottabb lehet. A kutatási adatok (illetve az egész kutatási folyamat) megfelelő, a reprodukálhatóságot vagy újra-felhasználhatóságot biztosító dokumentálásához szükség lehet a felhasznált műszerek, szoftverek, módszerek, de akár az egész laboratórium, obszervatórium dokumentálására. A publikációk esetében elvárás ugyan, hogy ezekre legyen valamilyen utalás, de a publikációk terjedelmi korlátai miatt ez gyakorta nem lehet a reprodukáláshoz, ellenőrzéshez elegendően részletes.

A könyvtárak fontos szerepe a fent említett részletes dokumentációk ez könyvtári zsargonban a szürke irodalom - tárolása, hozzáférhetővé és hivatkozhatóvá tétele.

\section{8.) Egyedi AZONOSÍTók}

Kulcsfontosságú az egyedi, állandó azonosítók használata. Manapság a leginkább népszerű a DOI, illetve az ORCID. Az előbbi alkalmas mind publikációk, mind a szürke irodalom, mind a kutatási adatcsomagok vagy rekordok azonosítására, az utóbbi szerzőazonosító. A kutatási folyamatban nagy igény van a résztvevő intézmények, illetve a kutatáshoz felhasznált pályázati támogatások azonosítására is. Ilyen azonosítási lehetőségeket kínál rendre a GRID és a Funder Registry. $\mathrm{Az}$ adatokat használó cikkek DOI-jait el kell helyezni az adatok leíró metaadataiban. Ideális esetben az adatok újrafelhasználásával foglalkozó cikkekre való hivatkozásokkal (és azok DOI-jaival) is lehet bővíteni utólagosan a metaadatokat. 
Míg a többi azonosítót a metaadatok gazdagítására kell használni, magának az adatállománynak DOI-t kell adni. Erre a célra a DataCite DOI alkalmas. Fontos kérdés a granularitás: egy nagy csomagba kell minden adatot összevonni, és annak DOI-t adni, vagy logikus részenként, esetleg minden egyes részadatnak szüksége van DOI-ra? Sajnos, a granularitás kezelése a DOI definícióban és a feloldási mechanizmusokban nem szerepel, ezt öntevékenyen kell kialakítani. Mindazonáltal a könyvtári gyakorlatban kevés DOI kiadását, egyszerű sémákat kell előnyben részesíteni.

A nagyszámú DOI hozzárendelése manuálisan amúgy sem kivihető - itt már automatizmusokra van szükség, amit esetleg az adatrepozitóriumszoftverek vagy adatbázis-szoftverek lehetnek képesek a DataCite rendszerén keresztül regisztrálni.

Újrafelhasznált adatok esetében akkor logikus új DOI-k regisztrálása, ha az adatállományt nem egészében használják (pl. egy dinamikus adatbázisból egy SQL lekérdezés eredményét). Ilyenkor a lekérdezéssel kapott adatokat célszerű archiválni, és új DOI-val ellátni. Persze a metaadatokban hivatkozni kell az eredeti adatbázis DOI-jára, amennyiben van ilyen.

\section{9.) Az aDATOK FAIR MiVOLTA NEM ANNYiRa ÁLLAPOT, MINT FOLYAMAT (FAIR IS A JOURNEY)}

Egy adatcsomag ritkán képes minden előírásnak megfelelni - már csupán azért sem, mert az évek során maguk az elvárások is változnak. Ez részben azt jelenti, hogy a hiányosan dokumentált, nem minden szempontnak megfelelő adatközlés is jobb, mintha az adatok a fiókban maradnának. Másrészt az adatok elhelyezése, leírása lehet egy iteratív folyamat. Beleértve azt is, hogy hosszú távon szükség lehet az adatok más formátumba való migrálására, a metaadatok kiegészítésére, az adatokkal kapcsolatban az elhelyezés óta történt fejlemények dokumentálására. A hazai könyvtárakban, attól tartunk, nemigen vannak erőforrások erre - ezért is fontos az előrelátó gondoskodás (lásd fentebb). 
Valamelyes utógondozásra, persze, van lehetőség - a publikációs repozitóriumok esetében is megszokhatták már a könyvtárosok az újabb, javított verziókra vagy javított metaadatokra vonatkozó szerzői vagy olvasói kéréseket. A nyílt hozzáférés minőségbiztosítási szempontból is fontos: amilyen hibát, problémát a könyvtárosok nem vesznek észre, azt az olvasók (felhasználók) észrevehetik.

\section{0.) SZABÁLYOZÁSOK, ADATKEZELÉSI TERVEK}

A nyílt hozzáféréshez hasonlóan a könyvtáraknak szerepük lehet a kutatási adatok kezelésére vonatkozó szabályozások kialakításában ha ez a szerep csekélyebb is. Nem csupán az illetékesség, tapasztalat kisebb, de ezen a területen a szabályozások sem lehetnek olyan részletesek, olyan egyértelműek. Nagyon változatos az egyes területek, sőt, azon belül az egyes projektek adatkezelése. Csak nagy vonalakban vagy áttételesen lehet szabályozni. Kevesebb a külföldi példa is, amire támaszkodni lehetne.

Az egyik lehetőség - ez már Magyarországon is megvalósul az OTKA pályázatoknál - az adatkezelési tervek megkövetelése. Az adatkezelési tervek elkészítésének támogatása viszont fontos könyvtári szerep.

\section{1.) A kutatási adatok Nyilvántartása}

A nyilvántartás egyik formája a projektbeszámoló - ez a finanszírozó számára jelzi az adatkezelési terv megvalósulását. Fontos azonban, hogy az intézményi és kutatói teljesítmény-nyilvántartásba is bekerüljenek a nyilvánosságra hozott kutatási adatok, a szerzőség, intézményi affiliáció és a felhasznált pályázati támogatás összekapcsolásával. Magyarországon az MTMT lehetőséget ad kutatási adatok rögzítésére.

Lehetőség van - a publikációkhoz hasonlóan - a közzétett kutatási adatok hatásának mérésére is, az idézéseken keresztül. A közleményekhez felhasznált, más projektek által létrehozott és közzétett adatokra természetesen hivatkozni kell, méghozzá DOI-val. Ezek a hivatkozások 
az indexelt folyóiratokból bekerülnek a Clarivate Data Citation Index-ébe. Az MTMT is rögzíteni tudja a nyilvántartott adatokra érkezett hivatkozásokat. A könyvtárosok részt vehetnek a hivatkozások gyüjtésében.

\section{2.) Publikus kutatási adatok keresése}

Mint ahogy a szakirodalom összegyüjtése az egyik első lépése egy kutatási projektnek, a tervezett vizsgálathoz kapcsolódó korábbi kutatások adatainak felderítése is meg kell előzze a saját adatgyüjtést. Mi az, ami már létezik, hozzáférhető, így nem kell összegyüjteni, megmérni, megfigyelni, modellezni? A felvetett kérdést meg lehet-e válaszolni már létező adatok alapján? Vannak-e olyan publikus adatok, amelyek kiegészíthetik az új projekt során keletkezőket?

A hatékony adatkeresés a szakirodalmi kereséssel rokonítható. A könyvtárosoknak meg kell ismerniük az általános adat-aggregátorokat (mint az EOSC, a csillagászatban az Astrophysics Data System) és adatbankokat, fel kell készülniük, hogy esetleg segíteniük kell a kutatóknak az adatokhoz való hozzáférésben.

Túl a kifejezetten adatkeresésre készült szolgáltatásokon a szakirodalmi keresés is szolgáltathat eredményeket. A NASA/SAO ADS csillagászati bibliográfiai adatbázis biztosít olyan keresési lehetőséget, amellyel felderíthető, hogy milyen adatbázis tartalmaz egy adott cikkhez társítható adatokat. (Elképzelhető egy olyan keresés, amelyben egy szerzőnévhez vagy objektum-azonosítóhoz kapcsolódó, bizonyos archívumban tárolt adatok léte felderíthető.) Ez előrevetíti, hogy bibliográfiai/könyvtári adatbázisokban, könyvtárosi tudással lehet kutatási adatokat felderíteni.

\section{3.) MunkafolyamatoK KialakítÁsa a KUTATÁsi adatoK KeZelÉSÉBEN}

Vitathatatlan, hogy a kutatási adatok megfelelő kezelése - tervezés, dokumentálás, ellenőrzés, egyedi azonosítók biztosítása s minden, ami 
szükséges lehet - jelentős terheket jelent. Természetesen a befektetett munka a későbbiekben - a kutatási eredmények verifikálásánál, újrafelhasználásánál - jelentős könnyebbséget, megtakarítást eredményezhet. Mindazonáltal nehéz a megfelelő adatkezelési gyakorlatot biztosítani. Minél inkább sikerül az adatkezelési szempontokat a munkafolyamatokba beépíteni és automatizálni, annál könnyebb lesz a megvalósítás (Holl, 2020a). A könyvtárosok segítséget nyújthatnak a munkafolyamatok megtervezésében is.

Van példa arra is, hogy az intézményi könyvtárak közreműködtek egy virtuális kutatási munkakörnyezet kialakításában (Sennyey és Kokas, 2020).

A kutatási adatok kezelésével kapcsolatos technológiák és szabványok kifejlesztésére és támogatására jött létre az Research Data Alliance (RDA); ennekhazai szervezete a HRDA.Érdemes a hazai fejlesztésekben és gyakorlatban az RDA szabványaira és a HRDA honosított anyagaira és szakértelmére támaszkodni. 


\section{Nyílt FORRÁSKÓDÚ, SZABAD KUTATÁSI SZOFTVEREK}

A nyílt forráskódú, szabad szoftverek hosszú múltra tekintenek vissza. Az 1970-es évek végéről a TeX szövegszedő rendszer (Donald Knuth), az 1980-as évek elejéről a GNU projekt (Richard Stallman), valamint az 1990 -es évek elejéről a Linux (Linus Torvalds) ismert példák.

A nyílt forráskódú szoftverek felhasználási jogainak rögzítésére számos jogi lehetőség áll rendelkezésre, mint a GNU GPL, az Apache, a BSD vagy a MIT licencek.

A szabad forráskód alkalmazását támogató projekt az Open Source Initiative ${ }^{9}$. Több tudományos folyóiratot is kiadnak a nyílt forráskód témája területén, mint a The Open Source Software ${ }^{10}$ és a Journal of Open Research Software (JORS) ${ }^{11}$.

Ugyancsak számos szoftver forráskód lista és tár (repozitórium) áll a fejlesztők rendelkezésére, előbbire példa a SourceForge ${ }^{12}$, utóbbira a GitHub $^{13}$. A kód repozitóriumok sok tekintetben különböznek az előző részekben tárgyalt repozitóriumoktól - lényeges, hogy funkcióikkal támogatják a csoportmunkát, és nem csupán a kódok referenciaként való archiválása, de változásaik nyomon követése is hangsúlyos.

Ajánljuk az Open Science MOOC ${ }^{14}$ oldalt, amelyen számos további információ található.

9 https://opensource.org/ (utolsó megtekintés: 2021. 09. 23.)

10 https://joss.theoj.org/(utolsó megtekintés: 2021. 09. 23.)

11 https://openresearchsoftware.metajnl.com/ (utolsó megtekintés: 2021. 09. 23.)

12 https://sourceforge.net/ (utolsó megtekintés: 2021. 09. 23.)

13 https://github.com/ (utolsó megtekintés: 2021. 09. 23.)

14 https://opensciencemooc.eu/ (utolsó megtekintés: 2021. 09. 23.) 


\section{Nyílt FORRÁSKóDÚ SZOFTVEREK ÉS A KÖNYVTÁRAK}

Ha jelenleg nem is elterjedt, de a jövőben elképzelhető, hogy a szakkönyvtáraknak szerepük lesz a nyílt forráskódú szoftverek területén is.

\section{1.) DOI Azonosítók}

A szoftverekre való hivatkozás lehetôségét is DOI-val lehet elérni. A GitHub útmutatójában a DOI-t a CERN Zenodo archívumában való archiválással javasolják beszerezni ${ }^{15}$.

\section{2.) HivatKozÁs NYílt FORRÁSKódú SZOFTVEREKRE}

Fontos, hogy a publikációk hivatkozzanak a felhasznált szoftverekre, lehetőleg DOI-val. Hivatkozási lehetőséget teremt, ha a szoftverről publikáció jelenik meg - erre alkalmas folyóirat például a JORS. De elképzelhető a szürke irodalomban való publikálás is - itt a szoftvert leíró cikket el lehet helyezni az intézményi repozitóriumban.

\section{3.) Metaadatok}

Érdemes a JORS cikkeit megnézni, milyen speciális metaadatokat kell megadni az általános DC leíró metaadatokon (pl. cím, szerzők, dátum, nyelv) túl:

- operációs rendszer;

- programozási nyelv;

- függőségek;

- kód repozitórium, projektnév;

- licenc.

15 https://guides.github.com/activities/citable-code/ (utolsó megtekintés: 2021. 09. 23.) 
A kutatásban használatos szoftverek FAIR tulajdonságaival foglalkozó RDA csoportok:

- FAIR4RS ${ }^{16}$;

- Software Source Code IG ${ }^{17}$.

4.) NyÍlt FORRÁSKÓDÚ SZOFTVEREK A KÖNYVTÁRAKBAN

Bár tárgykörünkön kívül esik ez a téma, meg kell említsük, hogy az integrált könyvtári rendszerek és platformok között is vannak nyílt forráskódúak - pl. a KOHA ${ }^{18}$.

Jelentős nyílt forráskódú könyvtári kezdeményezés a FOLIO ${ }^{19}$, ami az OSZK Országos Könyvtári Platform projektjének alapjául is szolgál (Lendvay, 2020).

\section{NYÍlt OKTATÁSI ERŐFORRÁSOK - OPEN EdUCATIONAL RESOURCES}

A nyílt oktatási lehetőségeket (Open Educational Resources) nem mindenki sorolja a nyílt tudomány körébe - de mivel a képzés a kutatás elválaszthatatlan része, és mivel az egyetemi könyvtáraknak e téren is feladatai vannak, mi foglalkozunk vele. A terület egyik úttörője az $\mathrm{MIT}^{20}$.

Az egyik legjelentősebb, hazánkban is elterjedt platform a MOOC (Massive Open Online Course).

16 https://www.rd-alliance.org/groups/fair-research-software-fair4rs-wg (utolsó megtekintés: 2021. 09. 23.)

17 https://www.rd-alliance.org/groups/software-source-code-ig (utolsó megtekintés: 2021. 09. 23.)

18 https://libereurope.eu/article/going-open-source-koha-in-an-academiclibrary/ (utolsó megtekintés: 2021. 09. 23.)

19 Future of Libraries is Open https://www.folio.org/ (utolsó megtekintés: 2021. 09. 23.)

20 https://ocw.mit.edu/ (utolsó megtekintés: 2021. 09. 23.) 
A könyvtárak szerepét az elektronikus tananyagok archiválásában Nagy (2018) tárgyalja, a hazai MOOC platformokat pedig Tarcsi (2019) szemlézi.

Könyvtári információs anyagok: IFLA ${ }^{21}$, SPARC Europe ${ }^{22}$.

\section{Nyílt tudományos bírálat (Open Peer Review)}

Új és gyorsan fejlődő terület, a tudományos publikációk bírálatának új paradigmája. Leírását lásd Ross-Hellauer (2017) cikkében, Görögh et al. (2017) projektjelentésében valamint a PLOS $^{23}$ és a FOSTER ${ }^{24}$ weboldalain.

A nyílt tudományos bírálat alapvető szempontjai:

- nyílt részvétel: a szerzők és a bírálók neve nyilvános;

- nyílt bírálatok (a bírálat nyilvánosan elérhető a publikáció mellett);

- nyílt együttműködés (párbeszéd a résztvevők között);

- nyílt részvétel (nem csupán a felkért bírálók vehetnek részt a bírálati folyamatban

- nyílt platform (a kiadóktól független platform);

- nyílt kéziratok (a beküldés után rögtön láthatók)

- nyílt megjegyzések utólagos hozzáfüzésének lehetősége.

Mind a nyílt tudományos bírálatot bevezető folyóiratok és kiadók (pl. az Atmospheric Chemistry and Physics, PeerJ, F1000Research), mind a kiadóktól független platformok (pl. PubPeer ${ }^{25}$, Publons $^{26}$ ) mind

21 https://www.ifla.org/files/assets/clm/news/oer_ifla_brief.pdf (utolsó megtekintés: 2021. 09. 23.)

22 https://sparceurope.org/open-education-in-european-libraries-of-highereducation-initial-results/ (utolsó megtekintés: 2021. 09. 23.)

23 https://plos.org/resource/open-peer-review/ (utolsó megtekintés: 2021. 09. 23.)

24 https://www.fosteropenscience.eu/learning/open-peer-review/\#/ id/5a17el50c2af65ldle3blbce (utolsó megtekintés: 2021. 09. 23.)

25 https://pubpeer.com/ (utolsó megtekintés: 2021. 09. 23.)

26 https://publons.com/about/home/ (utolsó megtekintés: 2021. 09. 23.) 
az úgynevezett „overlay journal”-ek (repozitóriumokban elhelyezett kéziratokat válogató folyóiratok, pl. az Open Journal of Astrophysics) fontosak a megvalósításban. Ez utóbbiakról lásd Gibney (2016).

A könyvtáraknak egyfelől tájékoztatási feladatuk lehet, másfelől a könyvtárak által működtetett vagy használt kutatásértékeléshez használatos adatbázisokban (MTMT, CRIS rendszerek) előbb-utóbb meg fognak jelenni az egyes kutatók bírálati tevékenységének mutatói. A repozitóriumokban archivált cikkek mellé pedig bekerülhetnek a bírálatok. (A REAL-d-ben 2010 óta archivált MTA doktori dolgozatok mellett már megtalálhatóak a bírálatok is.)

Könyvtári tájékoztatók a nyílt tudományos bírálatról: ACRL 27, OU²8.

\section{Közösségi tudomány (Citizen Science)}

A közösségi tudománnyal részletesebben kötetünk külön fejezete foglalkozik. Itt néhány platformot ismertetünk.

$\mathrm{Az}$ Európai Unió EU-CITIZEN.SCIENCE projektje ${ }^{29}$ lehetséges kezdőpont a tájékozódáshoz. Az Egyesült Államokban hasonló gyüjtőoldal a citizenscience.gov ${ }^{30}$. Közösségi tudományos projektek webes felületeinek kialakítását támogató platformok:

- Ecsite - EU Cítizen Science platform ${ }^{31}$

- Zooniverse.

27 http://www.ala.org/acrl/publications/keeping_up_with/opr (utolsó megtekintés: 2021. 09. 23.)

28 https://libraries.ou.edu/content/establish-your-expertise-open-peer-review (utolsó megtekintés: 2021. 09. 23.)

29 https://eu-citizen.science/ (utolsó megtekintés: 2021. 09. 23.)

30 https://www.citizenscience.gov/ (utolsó megtekintés: 2021. 09. 23.)

31 https://www.ecsite.eu/activities-and-services/projects (utolsó megtekintés: 2021. 09. 23.) 


\section{Nyílt kutatási JegyzőKönYvek (Open Lab Notebooks)}

A kísérleteket, a kutatási munkafolyamatokat egyre inkább automatizálni lehet. Az amúgy is gépesített, informatikai környezetben megvalósuló, vagy legalábbis informatikai eszközökkel irányítható munkafolyamat lekódolható, és eltárolva újrafuttatható (szükség esetén változtatásokkal). A munkafolyamat-automatizálás jelentősen megkönnyíti a kutatást, különböző eljárások és paraméterek próbálhatók végig rövid idő alatt. Maga a megfigyelés, a kísérlet is megismételhető lehet esetenként, de a szimuláció, az adatfeldolgozás, a vizualizáció, a publikáció technikai elkészítése mindenképp.

A terület áttekintését Schapira et al. (2019) cikkében találhatjuk.

A legelterjedtebben használt szoftver a JupyterNotebooks ${ }^{32}$.

A hagyományos (szöveges) kísérleti megosztására szolgáló platform az openlabnotebooks ${ }^{33}$.

32 https://jupyter.org/ (utolsó megtekintés: 2021. 09. 23.)

33 https://openlabnotebooks.org/ (utolsó megtekintés: 2021. 09. 23.) 


\section{Appendix}

\section{OAI-PMH - Protocol for Metadata Harvesting}

Az Open Archives Initiative által kidolgozott metadatat-aggregációs protokolli34. Magyar nyelvü leírás a SZTAKI és a MEK HEKTÁR projektje keretében készültt ${ }^{35}$.

A protokollt támogatják a különböző, nyílt forráskódú és szabad repozitórium-szoftverek, mint az EPrints, a DSpace és Dataverse, és a hasonlóan szabad Open Journal Systems folyóiratmenedzselő és publikációs platform. Aggregátor oldalon használja a magyar OAI közös kereső"36, a DART-Europe európai e-disszertációs portál37, a Jisc CORE ${ }^{38}$, a Bielefeld Academic Search Engine (BASE) ${ }^{39}$, a szegedi CONTENTA repozitóriumok közös keresője (Farkas és Sándor, 2020) és a PRIMO, hogy csak példákat soroljunk.

\section{SWORD}

Az Atom Publishing Protocol-ra épülő teljes szövegű tartalmak és metaadataik cseréjét lehetővé tevő egyszerű protokoll (Simple Web-service Offering Repository Deposit) ${ }^{40}$. Alapvető fontosságú a különböző digitális szolgáltatások között magvalósított adatcsere automatizálásában.

Ezt a protokollt használja a repozitóriumi feltöltés MTMT-ből való kezdeményezését lehetővé tevő szolgáltatás. A protokollt támogatják az elterjedt, szabad forráskódú, ingyenes repozitórium-szoftverek, mint az EPrints és a DSpace. Az MTMT-ben való alkalmazását megelőző kísérletekről l. Holl et al. (2009).

34 https://www.openarchives.org/pmh/ (utolsó megtekintés: 2021. 09. 23.)

35 http://hektar.sztaki.hu/oai.html (utolsó megtekintés: 2021. 09. 23.)

36 http://oaikereso.sztaki.hu/ (utolsó megtekintés: 2021. 09. 23.)

37 https://www.dart-europe.org/ (utolsó megtekintés: 2021. 09. 23.)

38 https://core.ac.uk/ (utolsó megtekintés: 2021. 09. 23.)

39 https://www.base-search.net/ (utolsó megtekintés: 2021. 09. 23.)

40 http://swordapp.org/ (utolsó megtekintés: 2021. 09. 23.) 


\section{REPOZITÓRIUM}

A repozitóriumok olyan digitális könyvtári szolgáltatások, amelyek az Open Archives Initiative nyomán jöttek létre. Nem minden weben elérhető digitális tartalomgyüjteményt lehet így nevezni - a repozitóriumok lényegi tulajdonságai a következők (a korábbiakban az elvárásokat inkább technikai szempontból soroltuk fel):

- nyílt hozzáférés biztosítása (a tartalmak többségéhez);

- teljes szövegü tartalmak szolgáltatása;

- aggregálhatóság;

- hosszú távú (vagy legalábbis évtizedekre való) hozzáférés biztosítása;

- minőségbiztosítás (könyvtárosi ellenőrzés).

Ezen felül a repozitóriumok többnyire megfelelnek az alábbi kritériumoknak is:

- kutatói önfeltöltés lehetősége;

- a szolgáltatások közötti tartalomcserét támogató mechanizmus;

- hozzáférési korlátozások alkalmazásának lehetősége.

A hazai repozitóriumokat üzemeltető közösség szakmai szervezete a HUNOR ${ }^{41}$. Hazai minősítő szervezet az MTMT Repozitóriumminősítő Bizottsága ${ }^{42}$.

A repozitóriumok megújítására, szolgáltatásaik bővítésére nagy igény mutatkozik (Holl, 2018c). Fejlesztésre kényszeríthetnek egyes repozitóriumokat az EU vagy a Plan S követelményei ${ }^{43}$.

41 https://openscience.hu/hunor/ (utolsó megtekintés: 2021. 09. 23.)

42 https://www.mtmt.hu/repozitoriumminosito-szakbizottsag (utolsó megtekintés: 2021. 09. 23.)

43 https://www.coalition-s.org/plan-s-practical-advice/ (utolsó megtekintés: 2021. 09. 23.) 


\section{DOI - Digital Object Identifier}

Állandó, egyedi azonosító digitális formában (is) létező objektumok számára. A Handle technológián alapul ${ }^{44}$. A DOI rendszer mögött az International DOI Foundation áll ${ }^{45}$.

A DOI azonosítók kiadása DOI ügynökségeken keresztül történik, ilyen a CrossRef ${ }^{46}$ és a DataCite ${ }^{47}$.

A DOI előnyei:

- a dokumentum elérési helyének változása esetén sem változó link megadása (ehhez az kell, hogy a dokumentum helyének megváltozását követően az adatgazda az új URL-t átvezesse a DOI adatbázisba (ezt a Handle rendszer biztosítja);

- kereshetőség a DOI adatbázisban rögzített adatok alapján (ehhez, persze, elegendő adatot meg kell adni);

- hivatkozások nyilvántarthatósága (pl. a CrossRef Cited-by szolgáltatásának használatával);

- láthatóság növekedést eredményez (CrossRef - a hivatkozó cikkeket olvasók kattintásain keresztül);

- a kutatásfinanszírozók és a CRIS rendszerek (MTMT-t is beleértve) számára jobb lehetőségeket kínál a kutatási termékek nyilvántartására.

A DOI azonosítók általában pénzbe kerülnek. A CrossRef szabályai szerkesztőségi vagy szerzői többletmunkára köteleznek (irodalomjegyzékben DOI linkek elhelyezése).

Az MTA KIK DOI regisztrációs szolgáltatásairól a weben lehet tájékozódni ${ }^{48}$.

44 https://www.handle.net// (utolsó megtekintés: 2021. 09. 23.)

45 https://www.doi.org/index.html (utolsó megtekintés: 2021. 09. 23.)

46 https://www.crossref.org/ (utolsó megtekintés: 2021. 09. 23.)

47 https://datacite.org/ (utolsó megtekintés: 2021. 09. 23.)

48 https://openaccess.mtak.hu/index.php/kiadoknak/doi (utolsó megtekintés: 2021. 09. 23.) 


\section{ORCID - Open Researcher and Contributor ID}

Szerzőazonosító rendszer, az ISNI-vel megegyező technológiával, annak részeként ${ }^{49}$. Az azonosítóról bővebben lásd Holl és Bilicsi (2017) cikkét. Az ORCID azonosító megadását számos folyóirat megköveteli, és számos szoftver támogatja. Az MTMT biztosítja az ORCID azonosító hiteles bevitelét, és az ORCID-on keresztül való bejelentkezést is.

Csak akkor van értelme az azonosító használatának, ha a kutató az ORCID profiljában megad különböző adatokat (mind végzettségről, mind a munkahelyeiről, mind a legfontosabb publikációit).

\section{FAIR - Findable, Accessible, Interoperable, Reusable}

A nyílt tudomány (Open Science) mozgalom eredeti célkitűzései szerint a tudományos közlemények szabad hozzáférhetőségéhez hasonlóan a kutatási adatok is szabadon hozzáférhetővé kell váljanak. Mivel ez sok esetben akadályokba ütközik, paradigmaváltás történt: „a kutatási adatok legyenek annyira nyíltak, amennyire lehetséges, és annyira zártak, amennyire szükséges” („As open as possible, as closed as necessary”). A kutatási eredmények ellenőrzéséhez szükséges az adatok rendelkezésre állása és a jó dokumentáció. Újrafelhasználásukhoz pedig megtalálhatónak, szabványosnak kell lenniük, és nyilvánvalóak kell legyenek a felhasználás feltételei.

A FAIR betűszó a következőképp oldható fel: Findable, Accessible, Interoperable, Reusable (megtalálható, hozzáférhető, szabványos, újrafelhasználható).

2016-ban jelentek meg a FAIR alapelvek (Wilkinson, 2016). Az alapelvek leírása megtalálható a FORCEll és a GoFAIR honlapjain ${ }^{50}$.

49 https://orcid.org (utolsó megtekintés: 2021. 09. 23.)

50 https://www.forcell.org/group/fairgroup/fairprinciples; https://www.go-fair.org/fair-principles (utolsó megtekintés: 2021. 09. 23.) 
A betűszóban összegzett alapelvek lényege tömören a következő:

F: Findable (megtalálható)

- Egyedi azonosítóval rendelkezik (pl. DOI);

- gazdagon el van látva leíró adatokkal (metaadatok);

- be van jegyezve, indexálva van valamilyen nyilvános, kereshető szolgáltatásba.

\section{A: Accessible (hozzáférhető)}

- Az egyedi azonosítón keresztül mind a leíró adatok, mind maguk az adatok elérhetőek valamilyen szabványos protokoll segítségével;

- a protokoll nyílt, ingyenes, elterjedt;

- a protokoll lehetővé teszi az azonosítást és a jogosultság-kezelést, amennyiben erre szükség van;

- a leíró adatok akkor is hozzáférhetőek, ha az adatok már nem.

I: Interoperable (szabványos)

- Az adatok és a leíró adatok szabványos és értelmezhető formában vannak;

- a leíráshoz, adatrögzítéshez, dokumentációhoz használt szótárak maguk is eleget tesznek a FAIR alapelveknek;

- sok kereszthivatkozás segíti az értelmezést.

R: Reusable (újra-felhasználható)

- Egyértelmű felhasználási licenc áll rendelkezésre;

- az adatok származása, keletkezése jól dokumentált;

- megfelel a tudományterületi szabványoknak.

A gyakorlatban alkalmazható FAIR kritériumokról bővebb információ található az EOSC FAIR WG Metrics and Certification TF anyagaiban, amelyek hivatkoznak a különböző releváns projektek dokumentumaira is. 


\section{CRIS - Current Research Information System}

A kutatásirányítást támogató komplex információs rendszer. Adatbázisaiban információk találhatók a kutatókról, a publikációkról, a projektekről, a kutatási infrastruktúrákról. Működhet intézményi, de országos szinten is. Magyarországon nincs integrált országos CRIS rendszer, de az MTMT betölti a publikációs nyilvántartó szerepét. Nemzetközi, CRIS támogató szervezet az euroCRIS ${ }^{51}$. A CRIS információk szabványa a Common European Research Information Format (CERIF) ${ }^{52}$.

Léteznek kommerciális CRIS szoftverek, mi itt a szabad forráskódú, Dspace alapú Dspace-SRIS-t említjük meg ${ }^{53}$.

\section{EOSC - European Open Science Cloud}

Európai kezdeményezés egy FAIR alapokon működő, különböző szolgáltatásokat integráló felhő és portál kialakítására ${ }^{54}$.

\section{RDA - Research Data Alliance}

A kutatási adatkezelés technikái és szabványai kidolgozására és támogatására létrejött szervezet, egyéni tagsággal ${ }^{55}$. Magyar tagszervezete a HRDA ${ }^{56}$.

51 https://eurocris.org/ (utolsó megtekintés: 2021. 09. 23.)

52 https://eurocris.org/services/main-features-cerif (utolsó megtekintés: 2021. 09. 23.)

53 https://wiki.lyrasis.org/display/DSPACECRIS/DSpace-CRIS+Home (utolsó megtekintés: 2021. 09. 23.)

54 https://ec.europa.eu/info/research-and-innovation/strategy/goals-research-andinnovation-policy/open-science/eosc_en (utolsó megtekintés: 2021. 09. 23.)

55 https://www.rd-alliance.org/ (utolsó megtekintés: 2021. 09. 23.)

56 http://hrda.hu/ (utolsó megtekintés: 2021. 09. 23.) 


\section{HUNOR - Hungarian Open Access Repositories}

A hazai (egyelőre inkább publikációs) repozitórium-üzemeltető intézményeket összefogó szervezet ${ }^{57}$.

\section{DMP - Data Management Plan}

Magyarul adatkezelési terv. Gyakran a kutatástámogató szervezetek kérik kutatási projektekhez - az NKFIH is kér ilyet.

Mire kell kitérnie egy adatkezelési tervnek?

- Adatok jellege, formátuma, mennyisége;

- hosszú távú megőrzés, egyedi azonosítók;

- kockázatok (pl. etikai, személyes adatok kezeléséből adódó);

- hozzáférhetőség, felhasználási licenc;

- adatkezelés esetleges költségei;

- adatok értéke, felhasználhatósága más projektekben;

- nyilvános, projekten kívüli adatok használata;

- és minden egyéb releváns körülmény.

Az adatkezelési terv élő dokumentum, a projekt során folyamatosan frissíteni kell!

A LIBER összeállított egy katalógust az adatkezelési tervekről (Data Management Plan Catalogue ${ }^{58}$.

\section{DDP - Domain Data Protocol}

Az adatkezelési terv alternatívája: a szakterületi adatkezelési protokoll ${ }^{59}$. A Science Europe javaslata.

57 https://openscience.hu/hunor/ (utolsó megtekintés: 2021. 09. 23.)

58 https://libereurope.eu/working-group/research-data-management/plans/ (utolsó megtekintés: 2021. 09. 23.)

59 http://www.scienceeurope.org/media/nsxdyvqn/se_guidance_document_ rdmps.pdf (utolsó megtekintés: 2021. 09. 23.) 


\section{Nyílt PUblikÁLÁSI SZOFTVEREK ÉS PLATFORMOK (OJS, OCS, OMP)}

Több nyílt forráskódú folyóirat-működtető szoftver létezik ${ }^{60}$. Mi itt a hazánkban is leggyakrabban használt, a Public Knowledge Project által létrehozott Open Journal Systems-t említjük, illetve „testvéreit”, az Open Conference Systems-et és az Open Monograph Press-et. Részletesebben lásd Holl és Bilicsi (2019) cikkét. Jeleznünk kell, hogy jelenleg az OCS elhanyagolt, frissítésre szoruló program.

Az OJS támogatja az OAI-PMH protokollt, a DOI regisztrációt.

\section{CoreTrustSeal}

A repozitórium-minősítés általánosan elfogadott, teljesíthető követelményeket támasztó rendszere a CoreTrustSeal ${ }^{61}$. Korábbi minősítési rendszerek fejlődésével, összeolvadásával jött létre. A tanúsítványok hierarchiájában ún. alapszintű tanúsítványt ad. A kiterjesztett és formális szintek az ISO 16363 vagy a DIN 31644 szerinti minősítést igénylik, az előbbi önminősítés, az utóbbi formális minősítési eljárás során ${ }^{62}$. (A rendszer kidolgozása idején az alapszintű tanúsítványt Data Seal of Approval-nak hívták. Ebből fejlődött ki a CoreTrustSeal.)

\section{DOAJ - Directory of Open Access Journals}

A DOAJ ${ }^{63}$ egyszerre nyilvántartás, minősítő szervezet és aggregátor.

60 http://edutechwiki.unige.ch/en/Journal_management_software (utolsó megtekintés: 2021. 09. 23.)

61 https://www.coretrustseal.org/ (utolsó megtekintés: 2021. 09. 23.)

62 http://www.trusteddigitalrepository.eu/Trusted\%20Digital\%20Repository.html (utolsó megtekintés: 2021. 09. 23.)

63 https://doaj.org/ (utolsó megtekintés: 2021. 09. 23.) 


\section{DOAB - Directory of Open Access Books}

Nyílt hozzáférésű könyvek listája ${ }^{64}$. Az OAPEN és az OpenEdition közös vállalkozása (további szervezetekkel együtt).

\section{SCOSS - Global Sustainability Coalition for Open Science Services}

A nyílt tudományt támogató infrastruktúrák finanszírozását támogató kezdeményezés ${ }^{65}$.

\section{COMPASS}

A hazai előfizetett elektronikus források lelőhely-adatbázisa, amit az EISZ biztosít. Az erőforrásról bővebb információt Sütő (2019) ad. A COMPASS+ az adatbázisok előfizetésével kapcsolatos döntéstámogató eszköz.

\section{MTMT}

A hazai kutatási bibliográfia. Működéséről bővebb leírást Holl (2021) ad.

Az MTMT nyilvános felületével ${ }^{66}$ is szolgálja a nyitottság elvét, valamint felvihetők a tudományos művek szabad hozzáférésű változatainak elérhetőségei (zöld és arany lakat jelzés), illetve készíthetők Open Access statisztikák.

\section{TÖRVÉNYI (ÉS EgYéB) SZABÁLYOZÁs MAGYARORSZÁGON}

- A PhD dolgozatok szabad eléréséről: 201l. évi CCIV. törvény a nemzeti felsőoktatásról (53/A. §. (2)).

64 https://www.doabooks.org/ (utolsó megtekintés: 2021. 09. 23.)

65 https://scoss.org/ (utolsó megtekintés: 2021. 09. 23.)

66 https://m2.mtmt.hu/gui2/ (utolsó megtekintés: 2021. 09. 23.) 
- A költségvetési forrás felhasználásával készült publikációk bibliográfiai adatainak kezelése az MTMT-ben: 1994. évi XL. törvény a Magyar Tudományos Akadémiáról (19/A. \$); 2011. évi CCIV. törvény a nemzeti felsőoktatásról (26. § (1)).

\section{IRODALOM}

Farkas és Sándor 2020

FARKAs Richárd, SÁNDOR Ákos, Digitalizált tartalmak közös keresője VuFind alapokon az SZTE Klebelsberg Könyvtárában = Networkshop 2020. Országos Online Konferencia, 2020. szeptember 2-4., Budapest, HUNGARNET Egyesület, 22-32. https://doi.org/10.31915/NWS.2020.3

Gibney 2016

Gibney, Elizabeth, Open journals that piggyback on arXiv gather momentum, Nature, 530, 04 February 2016, 117-118, https://doi.org/10.1038/nature.2015.19102

Görögh 2017

GöRÖGH Edit et al., OpenUP D3.1 Peer-review-landscape-report, 2017. https://doi.org/10.5281/zenodo.2557272

Holl 2009

Holl András, Karácsony Gyöngyi, Harangi Gabriella, Cserbák Márton, Teljes szövegü publikációk cseréje repozitóriumok között - a SWORD protokoll tesztelése az MTA Könyvtárában és a Debreceni Egyetem Könyvtárában = Networkshop 2009, 2009. április 15-17., Szeged. http://real.mtak.hu/65206/

Holl és Bilicsi 2017

Holl András, BILICsi Erika, ORCID - egy újabb szerzői azonositó tudományos közleményekhez, Könyvtári Figyelő, 2017/3, 346-350. http://real.mtak.hu/65517/ 
Holl 2018a

Holl András, Nyílt hozzáférés - elönyök, lehetôségek, feladatok, veszélyek = Erdélyi évszázadok: a kolozsvári Magyar Történeti Intézet évkönyve, Kolozsvár, Egyetemi Műhely Kiadó, 2018, 75-85.

http://real.mtak.hu/92213/

Holl 2018b

Holl András, A nyílt kutatási adatok kezelésének három oldala = Networkshop 2018 konferenciakiadvány, Budapest, HUNGARNET Egyesület, 2018, 59-63. https://doi.org/10.31915/NWS.2018.8

Holl 2018c

Holl András, Újragondolt repozitóriumok = AgriaMedia 2017, XII. Információtechnikai és Oktatástechnológiai Konferencia és Kiállítás, ICI-15 Nemzetközi Informatikai Konferencia, Eger, 2017. október 1113., Eger, Líceum Kiadó, 2017.

http://publikacio.uni-eszterhazy.hu/2343/

Holl és Bilicsi 2019

Holl András, Bilicsi Erika, Nyilt publikálási szoftverek és platformok = Networkshop 2019., Budapest, HUNGARNET Egyesület, 54-60. https://doi.org/10.31915/NWS.2019.7

Holl 2020a

Holl András, A kutatási adatok dokumentálását elősegitő szoftverek = Networkshop 2020, https://doi.org/10.31915/NWS.2020.1

Holl 2020b

Holl András, Parazita folyóiratok, Tudományos és Műszaki Tájékoztatás, 67 (7-8), 472-475.

https://tmt.omikk.bme.hu/tmt/article/view/12679 
Holl 2020c

Holl András, Milyen úton érjük el a tudományos közlemények nyílt hozzáférhetôségét?, Magyar Tudomány, 181 (1), 121-131.

https://doi.org/10.1556/2065.181.2020.1.14

Holl 2021

Holl András, A Magyar Tudományos Müvek Tára - alapvetô információk és múködési alapelvek, Magyar Tudomány, 182 (1), 81-89.

https://doi.org/10.1556/2065.182.2021.1.12

Lendvay 2020

Lendvay Miklós, Országos Könyvtári Platform - központi könyvtári szolgáltatások együttmüködő rendszere = Networkshop 2020.

https://doi.org/10.31915/NWS.2020.10

Micsik és Gárdos 2014

Micsik András, GÁrdos Judit, Tudományos repozitóriumok az MTA-ban: a KDK és a SZTAKI tanulságai = Informatika a felsőoktatásban, 2014. 08. 27-2014. 08. 29, Debrecen, Hungary.

https://eprints.sztaki.hu/8017/

Mons 2018

Mons, Barend, Data Stewardship for Open Science, CRC Press, 2018.

Nagy 2018

NAGY Gyula, A könyvtárak szerepe a digitális és elektronikus tananyagok archiválásában $=$ The role of libraries in archiving open educational resources = Networkshop 2018 konferenciakiadvány, Budapest, HUNGARNET Egyesület, 91-97.

https://doi.org/10.31915/NWS.2018.13

Ross-Hellauer 2017

Ross-Hellauer, Tony, What is open peer review? A systematic review, F1000Research, 2017, 6:588.

https://doi.org/10.12688/f1000research.11369.2 
Schapira 2019

SchapiRa, M. et al., Open laboratory notebooks: good for science, good for society, good for scientists, F1000Research, 8.87.

https://doi.org/10.12688/f1000research.17710.2

Sennyey és Kokas 2020

Sennyey Pongrácz, Kokas Károly, Digitális ökoszisztéma a könyvtári katalógusból? Egy texasi könyvtári kísérlet és tanulságai = Networkshop 2020. https://doi.org/10.31915/NWS.2020.2

Suber 2012

Suber, Peter, Open Access, MIT Press.

https://www.dropbox.com/s/5cxsyzs58a5yx5q/9286.pdf?dl=1

Sütő 2019

Süтő Péter, $A z$ elektronikus szakirodalmi információforrások hazai lelóhelyadatbázisa, a COMPASS = Networkshop 2019, Budapest, HUNGARNET Egyesület, 150-156.

https://doi.org/10.31915/NWS.2019.19

Tarcsi 2019

TARCsi László, A hazai MOOC portálok áttekintése, Opus et Educatio, 6. 1. https://doi.org/10.3311/ope.293

Wilkinson 2016

Wilkinson, Mark D. et al., The FAIR Guiding Principles for scientific data management and stewardship, Scientific data, vol. 3., 15. March 2016. https://doi.org/10.1038/sdata.2016.18 



\section{A kiadókKal kötött Read and Publish SZERZŐDÉSEK, ÉS A NYÍLT HOZZÁFÉRÉSÜ PUBLIKÁLÁS HAZAI LEHETŐSÉGEI}

\section{GaÁlné KaLydy DóRa}

Számba véve a nyílt tudományhoz kapcsolódó hazai gyakorlatokat, kiemelten kell foglalkoznunk az országos licenc szerződések keretén belül „kifizetett” publikációs díjakkal, melyeket az Elektronikus Információszolgáltatás (EISZ) Nemzeti Program tud érvényesíteni a konzorciumi tagintézmények javára és érdekében.

A 2001 óta működő EISZ Nemzeti Program a 1079/2012. (III.28.) kormányhatározat ${ }^{1}$ alapján 2012 januárjától az MTA Könyvtár és Információs Központon keresztül biztosítja az előfizetői kör tagjai számára a hozzáférést elektronikus tudományos tartalmakhoz nemzeti licensz vásárlásával. Az EISZ kínálatában több mint 70 szakirodalmi adatbázis érhető el 2021-ben. Tartalmát tekintve az átfogó, minden tudományterületre kiterjedő, interdiszciplináris adatbázisok mellett különféle szakadatbázisok is elérhetőek a rendszerben.

A program stratégiai céljai a széleskörű kutatástámogató szolgáltatás biztosítása, amely az elektronikus tudományos tartalomhoz való hozzáférés mellett az Open Access publikálás lehetőségét is kínálja a hazai kutatási és felsőoktatási szféra számára a hazai innováció támogatása és a magyar tudományos eredmények nemzetközi láthatóságának erősítése érdekében.

A projekt eredményeként a hazai szakkönyvtári hálózat folyamatos hozzáférést biztosít a kutatói közösség számára a kurrens tudományos tartalmakhoz és aktívan támogatja a kutatók publikálási tevékenységét. A teljes szövegü adatbázisok mellett a bibliográfiai és hivatkozáskereső adatbázisok segítik a szakirodalmi áttekintéseket és

1 Magyar Közlöny: http://www.kozlonyok.hu/ 
lehetőséget biztosítanak az intézmények tudományos működésének összehasonlítására.

Az EISZ Titkárság kezdetektől kereste az Open Access országos megvalósításának módját, azonban az első ún. Read and Publish megállapodásra csak 2018. évben került sor a Taylor and Francis kiadóval ${ }^{2}$.

A Read and Publish szerződéseket sokszor átmeneti szerződéseknek is hívjuk, ezek a szerződések arra hivatottak, hogy a résztvevőket átvezessék a kizárólag előfizetési díj megfizetéséből a kizárólag publikációs díj fizetésébe. Ezek az átmeneti szerződések egyszerre tartalmaznak előfizetési díjat, mely alapján a tudományos cikkeket olvasni lehet, és egyszerre biztosítanak publikációs lehetőséget megfelelő APC (Article Processing Charge - cikk feldolgozási díj) befizetésével, melynek eredményeképpen az így megjelent cikkek bárki számára nyílt hozzáféréssel elérhetők, letölthetők és olvashatók lesznek. Célunk az, hogy a Read and Publish díj együtt nem haladhatja meg az eredeti előfizetési (subscription) díjat. Az évek múlásával az arányoknak változniuk kell, a nagyobb összegű előfizetési díj csökken, ezzel párhuzamosan a publikációs díj megnő, amíg el nem érünk abba a kánaánba, ahol már csak publikációs díjat fizetnek a konzorciumi tagok, akik a befizetett összeg fejében jogosultak a publikálásra.

Az EISZ keretein belül külön-külön konzorcium áll fel egy-egy adtabázis elérésére. Azok az intézmények kutatói, oktatói, amelyek olyan konzorciumban vesznek részt, olyan szerződésbe fizetnek önrészt, amelyek nemcsak előfizetési díjat, hanem publikációs díjat is tartalmaznak, azon intézmény oktatói, kutatói jogosultak publikációjukat az adott kiadó által kínált teljesen $\mathrm{OA}$ vagy hibrid ${ }^{3}$ folyóiratokban megjelentetni.

2 Taylor and Francis szerződés: http://eisz.mtak.hu/images/szerzodesek/TF_2018.pdf

3 A folyóiratban vannak nyílt hozzáféréssel bárhonnan elérhetô cikkek és vannak olyan zárt cikkek, melyek csak előfizetéssel érhetők el. 
Ezek az APC díjak a nemzetközi kiadóknál 1.000 eurótól egészen 12.000 euróig rúghatnak a kiadó meghatározása alapján. A legtöbb kiadó pontosan megállapítja az APC díjra fordítható keretösszeget, az így megjelenő publikációk számát, külön a teljes (Fully) Open Access, külön a hibrid lapok vonatkozásában.

Miért jó ez a kiadónak, egyetemnek, országnak ...?

Az egyetemek és kutatóintézetek munkatársai mindig is publikáltak, az elmúlt évtizedeben kialakult „Publish or Parish” (publikálj vagy dögölj meg) kifejezés valóban jól tükrözi a kutatók és oktatók előmenetelért folytatott publikációs csatáját. A kutatók intézményének, az egyetemeknek és kutatóintézeteknek is érdeke a minél több publikáció, hiszen az intézmény tudományos kibocsátását is mérik világ,- illetve országos szinten. Az intézmények rangsorolása több összetevő eredménye, ebben a versenyben kiemeleten fontos szerepet játszik az intézmény munkatársainak publikációs száma, Hirschindexe, az intézményhez affiliált szerzőkre való hivatkozások száma. A rangsorokon kívül az eddigi gyakorlat szerint az intézmények kutatástámogatási finanszírozása is nagyban függött a tudományos kibocsátások mennyiségétől és minőségétől.

Általánosságban elfogadott, kutatásokon alapuló tény, hogy a nyílt hozzáféréssel megjelent cikkek láthatósága és a rájuk való hivatkozások száma magasabb, mint az előfizetéses folyóiratokban megjelent publikációké. ${ }^{4}$ Tehát az intézményeknek egyik oldalról érdeke, hogy minél több az intézményhez affiliált szerző cikke nyílt hozzáféréssel jelenjen meg. Ugyanakkor a szóban forgó szerződések esetében jelenleg még (ki tudja, meddig) fizetjük az előfizetési díjat is és az APC díjat is. Annak ellenére, hogy az intézmények számára a nyílt hozzáférésű publikációk megjelenése tudományértékelés szempontjából pozitív, a finanszírozás oldaláról még sok esetben megoldatlan kérdés a hihetetlen

4 https://en.wikipedia.org/wiki/Open_access (utolsó megtekintés: 2021. 07. 24.) A kötetünkben olvasható Soós Sándor és Kiss Anna tanulmánya, amely megerősíti a hipotézist. 
magas APC díjak miatt, melyek a tudományos információellátást századok óta végző könyvtárak tiltakozása ellenére is folyamatosan emelkednek.

A nemzeti tudományos kibocsátásunk minél nagyobb láthatósága létkérdés és nemzetstratégiai kérdés is. $\mathrm{Az}$, hogy kinek a nevéhez kapcsolódik egy-egy tudományos felfedezés, nem elhanyagolható, ismerve a Bolyai János-féle nemeuklideszi geometriára vonatkozó leírás körüli kérdésfeltevéseket. A tudományos világ sokáig vitatta, hogy Bolyai János vagy Nyikolaj Ivanovics Lobacsevszkij nevéhez füződik a felfedezés, melyet mi magyarok egyértelműen Bolyai Jánosnak tulajdonítunk annak ellenére, hogy lehetséges: hogy egymástól függetlenül jutottak ugyanarra a következtetésre. A tudományos világban a mai napig is, sőt talán jobban, mint bármikor, létkérdés, hogy ki mikor publikál egy-egy újdonságot vagy új ismérvet. Ha országosan tudjuk támogatni és átlátni, hogy mely intézményből milyen publikációk kerülnek ki, az segíti az innovációért és kutatásáért felelős országos vezetőket a döntéshozatalban és a tudományos marketingben. Hasznos és előremutató lenne, ha a magyar nyílt hozzáférésű publikációk számontartását és finanszírozását ilyen módon központilag tudnánk adminisztrálni. Ez a fajta centralizáció a központosítás jó formája. Szintén országos érdek füződik az állami pénzekből finanszírozott kutatások eredményeinek nyílt hozzáférésű publikációjához. Ma már minden kutatási pályázat (OTKA, Bolyai stb.) előírása, hogy az adott pályázati ciklus eredményeit nyílt hozzáférés biztosításával publikálni kell. (Ez természetesen lehet monográfia vagy cikk nyomtatott és elektronikus megjelenése repozitóriumokon keresztül.) A döntés, hogy mely intézmény mit és milyen folyóiratban publikál, minden esetben az adott intézmény döntési hatáskörében kell, hogy maradjon.

A tudományos információ birtoklása és közzététele nemcsak üzleti, hanem hatalmi kérdés is. ${ }^{5}$ Mára egyértelművé vált, hogy azok a kiadók, akik a kezdeti kockázatot felvállalták a nyílt hozzáférésű lapok

5 Monok István, Új hatalmi viszonyok a tudományos információk megosztásában = Könyvtári(?) Problémák, Budapest, MTA KIK, 2020, 19-29. 
indításával, nyertesek a tudományos közlemények kiadásának piacán. $\mathrm{Az}$ APC díjak folyamatos emelésével bizonyosan fedezik nemcsak az adott cikk elektronikus kiadási költségét, hanem számos egyéb költséget is, hiszen a lektorálást (peer review) honorárium nélkül végzik az adott tudományos terület képviselői. Ezenkívül pedig a profitorientált kiadók (nem az egyetemi kiadók) a teljesen nyílt hozzáférésű folyóiratok mellett meghagyták a hibrid és az előfizetéses folyóiratok megjelentetését is. Sok szempontból a nyílt hozzáférés mozgalom a tudományos előmenetelért folytatott küzdelem ördögi körének csapdájába esett, hiszen a tudományos világ ranking szemlélete meghatározza, hogy mi tudományos az Impakt Faktor (IF) mutatószámmal', és elvárja a tudományos világ, hogy aki fokozatot szeretne lépni, minél több olyan lapban publikáljon, melynek magas az IF mutatója. Ezzel ellehetetlenítették a teljesen OA folyóiratok indulását, hiszen sok kutató nem akart és/vagy nem tudott 0 IF folyóiratban publikálni, hiszen azzal az ő tudományterülete nem számol, akármilyen nagy szenzációt publikálna, az előmenetelébe nem számít. A tudományos világ belső hatalmi harcai blokkolják a tudományos folyóiratok nyílt hozzáférésűvé válását azzal, hogy elfogadták az üzleti világ érdekeit érvényesítő tudományelemzési módszereket.

Az EISZ Nemzeti Programban nincs két egyforma átmeneti szerződés a nyílt hozzáférésű publikációk szempontjából. A Magyar Tudományos Akadémia Könyvtár és Információs Központ 11 kiadóval kötött Read and Publish szerződést az Elektronikus Információszolgáltatás Nemzeti Program keretében 2021-ben. Általánosságban a kiadók a nyílt hozzáférésű kvótát (akár pénzben adják meg, akár megjelentethető cikkek számában) az alapján határozzák meg, hogy az adott ország kutatói mennyit publikáltak a kiadónál az elmúlt 1-2-3 évben. A 11 kiadóból három kiadó (Akadémiai Kiadó, Cambridge University Press, Royal Society of Chemistry) kínálja korlátlan számú publikáció

6 Az IF azt mutatja, hogy az előző kétéves időtartamban a folyóiratban lévő cikkekre mennyien hivatkoztak. Minél magasabb az IF szám, annál szívesebben publikálnak benne a szerzők. Bizonyos tudományterületeken előírás, hogy mennyi IF-t kell gyűjteni és ezt, teljesen helytelenül, azonosítják a szerzővel. 
megjelentetését, természetesen, ha a cikk megfelel a kiadó által felállított minőségbiztosítási kritériumoknak. Ezek a kiadók nem határoznak meg sem pénzügyi, sem számbeli korlátot, kizárólag a lektorálási feltételeknek kell megfelelni. A három kiadó nagyon különböző szempontokat mérlegelt döntésének meghozatalakor: a CUP először 2021-ben tette korlátlanná a megjelenő cikkek számát. A döntés megértéséhez látnunk kell, hogy 2020-ban a szerződésben rögzített 30 cikk helyett 17 cikk jelent meg a konzorciumi szerzőktől. A RSC igen szűk tudományterületet foglal magában, a konzorciumban összesen négy magyar intézmény van. 2020-ban egyetlen magyar szerzőjü cikk jelent meg nyílt hozzáféréssel a RSC lapjaiban, vagyis ők nem kockáztatnak igazából azzal, ha azt mondják, „korlátlan számú magyar kutató publikálhat”. Az Akadémiai Kiadó folyóiratai népszerűek. Itt jelenik meg a legtöbb intézményi (egyetemi és kutatóintézeti) folyóirat. 2020-ban 622 tanulmány jelent meg nyílt hozzáféréssel az előfizetői kör munkatársaitól.

A többi nyolc kiadóval kötött megállapodásban rögzítettük, hogy milyen összegért hány cikk jelenhet meg. 2020-ban két kiadónál merítettük ki a rendelkezésre álló kvótákat, a Wileynál októberre elértük a szerződött 230 cikket, a Springer Nature kiadónál pedig a teljesen (fully) OA cikkek kvótája merült ki novemberre (26l cikk), decemberben pedig elértük a maximum, 601 hibrid folyóiratokban megjelenő cikkek számát. Statisztikai szempontból a leghasználtabb adatbázis a 40 intézményt magában foglaló Science Direct konzorcium folyóiratcsomagja (Elsevier) 1000 OA publikálási kvótát tartalmazott, az elfogadott cikkek száma 771 volt 2020-ban.

Az átmeneti szerződésekkel kapcsolatban összefoglalóan elmondhatjuk, hogy 2020-ról 2021-re csekély előrelépés látható, egy kiadóval bővült (Oxford University Press) az OA lehetőséget biztosító kiadók száma, illetve a Cambridge University Press bővítette korlátlanra a publikációs lehetőséget. Sok esetben a kiadók nem az Open Access mozgalom elvárásai és követelményei alapján biztosítják a publikálási lehetőséget, hanem az előfizetésen felül plusz szolgáltatásként értelmezik. 
Ezekben az esetekben az EISZ Program nem köt szerződést, nem „vásárol” publikációkat, hiszen a kutatástámogatás egyik meghatározó trendjéhez csatlakozva az EISZ is elkötelezett a nyílt hozzáférés teljes átállása mellett, nem támogatjuk a tudományos tartalmak többszöri megvásárlását. Célunk, hogy lehetőségeinkhez képest, sürgessük a nyílt hozzáférés elterjedését, a tudományos információk megosztását. Dolgozunk azoknak a lehetőségeknek a megteremtésén, hogy a magyarországi kiadókkal is hasonló szerződéseket köthessünk, támogatva ezzel a magyar tudományos nyelv megtartását, illetve a hazai kiadók modernizálását. 



\section{Az „Open Access-előnyöK” megnyilvánulása A HAZAI TUDÁSPRODUKCIÓBAN: BIBLIOMETRIAI HATÁSVIZSGÁLAT ${ }^{1}$}

Soós SÁndor, Kiss AnNA

\section{Bevezetés}

Az „Open Access-előnyök” körét mára széleskörű tudományos, gazdasági és társadalmi hatások listájaként szokás nyilvántartani. Ezek közé tartozik a tudományos (publikációs - láthatósági, idézettségi előnyökben megnyilvánuló, illetve pályázati) versenyképesség, a nemzetköziesedés, az ipar - akadémia tudásáramlás akadálytalansága és ezen keresztül a tudásmenedzsment- és innovációs folyamatok felgyorsítása, a kutatás társadalmi átláthatóságának és a kutatásértékelés lehetőségeinek jelentős kibővítése.

Az egyik legelterjedtebb feltételezés, hogy az OA-publikációk - főként nagyobb láthatóságuk, elérhetőségük miatt - magasabb idézettséget érnek el, mint a velük összemérhető, azonos szakterületi, jellegbeli, szerzőségi stb. csoportba sorolható nem-OA közlemények. A hipotézis vitatott (lásd a Kapcsolódó kutatások című szakaszt), ugyanakkor az evidenciák többsége általánosságban alátámasztja az ún. OA-idézettségi előnyt.

Az alábbiakban bemutatott kutatás az OA-idézettségi előny posztulátumából indul ki, célja pedig annak empirikus, „tényalapú” felmérése, hogy a nyílt hozzáférésű közlésnek a hazai tudományos kibocsátás vonatkozásában is tulajdonítható-e efféle előny, illetve, ha igen, ez az előny ténylegesen az OA-státusznak köszönhető-e. Ennek megfelelően a vizsgálat két kutatási kérdésre irányul:

1 A kutatást a Nemzeti Kutatási, Fejlesztési és Innovációs Hivatal

OTKA K 116163 számú pályázata támogatta. 
RQ1. Létezik, illetve kimutatható-e a hazai intézményekhez köthető Open Access közlemények körében idézettségi előny/fölény a nem nyílt hozzáférésű publikálással szemben?

RQ2. Mekkora hatással rendelkezik, mennyiben nyújt magyarázatot az OA-státusz az idézettség viselkedésére (feltételezett növelésére) vonatkozóan, ha elkülönítjük a többi, idézettséget befolyásoló tényező hatásától? E kérdés kapcsán milyen összefüggések mutathatók ki az OA-státusz és a további közleményjellemzők idézettségre gyakorolt hatása között?

A fenti kutatási kérdések mindegyike hazai viszonylatban merül fel. A kérdések ugyanakkor az alábbi szakaszban összefoglalt nemzetközi eredményekre reflektálnak.

\section{KaPCSOLÓDÓ KUTATÁSOK}

Lawrence (2001) volt az első, aki az OA-publikálásban rejlő lehetőségeket az idézettség növelésére megfogalmazta empirikus tanulmányban. 2001 óta számos tanulmány született, amelyek alátámasztják, avagy cáfolják az Open Access-publikáláshoz kapcsolódó potenciális idézettségi előny létezését. Az idézettségi előny hasznosságáról és következetességéről a különböző kutatási területeken turbulens vita zajlik, mert az idézettségi előny nagysága az egyes tudományágakban jelentősen eltérő. Az eddigi tanulmányok által azonosított általános tendencia azonban azt jelzi, hogy a legtöbb tudományágban legalább kismértékű összefüggés mutatkozik az OA-publikálás és a megnövekedett idézettségi között (1. táblázat). 
1. táblázat: Főbb tudományos publikációk, amelyek az OA-publikáláshoz kapcsolódó idézettségi előnyt vizsgálták és számszerüsítették.

\begin{tabular}{|c|c|c|}
\hline Szerző & Tudományterület & Hivatkozási előny \\
\hline Eysenbach (2006) & Természettudomány & $+210-+290 \%$ \\
\hline $\begin{array}{l}\text { Atchison and Bull } \\
(2015)\end{array}$ & Politikatudomány & $\begin{array}{l}\text { Statisztikailag } \\
\text { szignifikáns előny }\end{array}$ \\
\hline $\begin{array}{l}\text { Kousha and Abdoli } \\
(2010)\end{array}$ & Agrártudomány & $+621 \%$ \\
\hline Davis (2011) & $\begin{array}{l}\text { Társadalom és } \\
\text { Bölcsészettudományok }\end{array}$ & $\begin{array}{l}+1 \% \text {, de statisztikai- } \\
\text { lag nem megkülön- } \\
\text { böztethető }\end{array}$ \\
\hline Sahu et al. (2015) & Egészségtudományok & $+300 \%-+450 \%$ \\
\hline $\begin{array}{l}\text { Wohlrabe and } \\
\text { Birkmeier (2014) }\end{array}$ & Gazdaságtudomány & $\begin{array}{l}+35 \%-+64 \% \\
\text { a használt adatbázis } \\
\text { függvényében }\end{array}$ \\
\hline Zhang (2006) & Kommunikációtudomány & $200 \%$ \\
\hline Lawrence (2001) & Számítástudományok & $+157 \%-+284 \%$ \\
\hline \multirow[t]{2}{*}{ Xu et al. (2011) } & $\begin{array}{l}\text { Bölcsészettudományok, } \\
\text { Elettudományok, Matematika és } \\
\text { Fizika, Egészségtudományok, }\end{array}$ & $-49.24 \%-+87.73 \%$ \\
\hline & Társadalomtudományok & \\
\hline Hajjem et al. (2006) & $\begin{array}{l}\text { Biológia, Pszichológia és } \\
\text { Neveléstudomány, Szociológia, } \\
\text { Egészségtudomány, } \\
\text { Politikatudomány, } \\
\text { Gazdaságtudomany, } \\
\text { Jogtudomány, Gazdálkodás és } \\
\text { menedzsment, }\end{array}$ & $+36 \%-172 \%$ \\
\hline $\begin{array}{l}\text { McCabe and Snyder } \\
(2014)\end{array}$ & $\begin{array}{l}\text { Ökológia, Botanika, } \\
\text { Multidiszciplináris tudományok } \\
\text { és Biológia }\end{array}$ & $+8 \%$ \\
\hline $\begin{array}{l}\text { Evans and Reimer } \\
(2009)\end{array}$ & Mindegyik & $\begin{array}{l}\text { +8\% az új } \\
\text { publikációkra; } \\
\text { +16\% a fejlődő } \\
\text { országokban } \\
\text { készült publikációk }\end{array}$ \\
\hline Wang et al. (2015) & Mindegyik & $+111 \%-+152 \%$ \\
\hline
\end{tabular}


Bizonyítékok támasztják alá az OA-publikáláshoz kapcsolódó idézettségi előnyt, ennek az előnynek a nagysága továbbra is jelentősen változó. Az OA-publikáláshoz kapcsolódó idézettségi előnyre vonatkozó becslések +8\% (biológia) és $+600 \%$ (agrártudomány) között mozognak (Swan 2010; Wagner 2010). A megfigyelt hivatkozási előnyök jelentős heterogenitása a különböző tudományterületeken található publikációs és idézési hagyományokból és kultúrákból adódhat, valamint az OA típusa, és az alkalmazott bibliometriai indikátor is szerepet játszhat az idézettségi előny eltérő mértékében. A Green OA például közösségi standardnek számít olyan területeken, mint a nagy energiájú fizika vagy a matematika, de még nem terjedt el széles körben az élettudományok területén. Az ilyen „pre-print” publikációk az idézetek átlagos számának, az összes idézetek számának és az idézetek akkumulációs sebességének általános növekedésével is összefüggésben állnak (Aman 2014; Gentil-Beccot et al. 2010). Más tanulmányok csak akkor tudtak alátámasztani a nagy idézettségi előnyöket (+600\%), ha a releváns előrejelzéseket kihagyták (McCabe \& Snyder 2014), ami potenciális torzító hatást jelez. Ha az idézettségi előny kicsi vagy egyáltalán nem létezik, ez arra utalhat, hogy ezeken a kutatási területeken megfelelő hozzáférés áll rendelkezésre a szakirodalomhoz, így az OA nem biztosít lokális hozzáférési előnyt, vagy az OA elfogadása még nem érte el azt a szintet, amikor minden ilyen előny statisztikailag kimutathatóvá vált.

Eysenbach (2006) egy longitudinális tanulmányban összehasonlította a Proceedings of the National Academy of Sciences multidiszciplináris folyóiratban megjelent publikációk egy kohortjának idézettségi hatását, amely mind az OA, mind a nem OA közzétételi lehetőségeket kínál. Az eredmények azt mutatták, hogy a nem OA-publikációk kétszer nagyobb valószínűséggel maradnak idézetlenek hat hónappal a megjelenés után, mint az OA-publikációk. Ezenkívülaz OA-publikációk átlagos idézettségi száma több mint kétszeresére nőtt, összehasonlítva a nem OA-publikációkkal. A tanulmány megkülönböztette az OApublikációk típusát is, nevezetesen a Green OA és a Gold OA-t. 
A Gold OA-nek nagyobb volt az általános tudományos hatása, mint a Green OA publikációknak.

A pszichológia területén megjelent publikációk tanulmányozása során Anderson (2013) megállapította, hogy a szövegben közölt finanszírozási forrásokat megjelenítő publikációkat gyakrabban idézték, és ezen publikációk kapcsolódtak más, magasan idézett publikációkhoz, összehasonlítva a finanszírozási forrásokat fel nem tüntető publikációkkal. Zhao (2010) könyvtár- és információtudományi területen végzett hasonló tanulmányában a támogatott kiadványok nagyobb idézettséggel bírtak, mint a támogatást nem kapó kiadványok. Bár ezek a tanulmányok azt mutatják, hogy a kutatások finanszírozása összefüggésben van a megnövekedett hivatkozási arányokkal, a publikációk hozzáférhetőségét egyik tanulmány sem vette figyelembe.

Craig és munkatársai 2007-ben készült kritikai elemzése során három nem kizárólagos posztulátumot vizsgált, amikor az OA és a nem OApublikációk közötti idézettségi különbségeket vizsgálta: az idézettségi előny 1) a publikáció OA státuszának köszönhető, 2) szelekciós torzítás (azaz a szerzők kiválasztják legjobb munkáikat, amelyeket nyilvánossá tesznek), és 3) korai megtekintési effektusok (azaz a publikáció rendelkezésre állásának hosszabbítása). Rámutattak olyan tanulmányokra, amelyek során az egyik posztulátum vizsgálatának eredménye (pl. a korai nézet) feltárta, hogy az idézések száma megmagyarázható egy másik posztulátummal (pl. szelekciós torzítás), és azt javasolták, hogy a későbbi tanulmányokban szigorúbb módszerekre van szükség az ok-okozati összefüggések vizsgálatához (Craig et al. 2007).

Az OA-publikációk és az idézettségi előny közötti lehetséges okozati viszonyok elhatárolásához és annak meghatározásához, hogy milyen feltételek mellett láthatjuk, hogy az OA hatással van-e az idézettségi mutatókra, jövőbeni kutatásokra lesz szükség. Ezt randomizált, kontrollált vizsgálatok útján lehet elvégezni minden tudományterületre kiterjedően, így szélesebb körű bizonyítékot szolgáltatnának a 
tudományterületekre specifikus OACA előfordulására. Sok releváns primer és néhány szekunder kutatás született már ebben a témában; ezek a tanulmányok értékes kontextust és áttekintést nyújtanak, azonban nem voltak átfogók, és az alkalmazott módszerek leírása nem biztosította a reprodukálhatóságot. Az OA-publikálás hatása az idézettségre továbbra sem egyértelmű, különösen a tudományágak, az adatforrások, a publikációs modellek és egyéb kontextusbeli tényezők figyelembevételével.

Langham-Putrow és munkatársai 2021-ben szisztematikus irodalmi áttekintést készítettek, amelyben 134 kutatást vizsgáltak az OA módjának, a publikációk típusainak és a vizsgált tudományágak eltéréseit az OACA-val összefüggésben. Elemzésük eredményei azt mutatták, hogy a vizsgálatba bevont kutatások többsége (47,8\%) alátámasztja az OA-publikáláshoz kapcsolódó idézettségi előnyt, míg 27,6\% nem mutatott ki idézettségi előnyt. A vizsgálatok 23,9\%-a szerint nem volt egyértelmü idézettségi előny, azonban bizonyos folyóiratok, bizonyos időszakok vagy tudományterületek előnyt jelentettek. Nem volt statisztikailag szignifikáns összefüggés az OA-publikációs mód és az eredmények között. Az OA-idézettségi előnyt alátámasztó megállapítások az OA módjától függetlenek: a zöld OA-ra irányuló vizsgálatok $72 \%$-a, az arany OA -ra összpontosítók 39,6\%-a és az OA módot nem megjelölő kutatások 52,2\%-a mutatta ki az OA-publikáláshoz kapcsolódó idézettségi előnyt. Statisztikailag szignifikáns összefüggést találtak a tudományterület és az OApublikáláshoz kapcsolódó idézettségi előny között $(\mathrm{X} 2(18,134)=$ 42,763, p <0,001). A multidiszciplináris tudományterülettel foglalkozó tanulmányok pozitív kapcsolatot mutattak OA publikáláshoz kapcsolódó idézettségi előnnyel. Az OA-publikáláshoz kapcsolódó idézettségi előnyre vonatkozó megállapítások gyakoribbak voltak a társadalomtudományokban (66,7\%), az orvostudományban és az egészségtudományokban (52,8\%), valamint a természettudományokban (45,5\%). Mind az agrártudományokban, mind a tudományterületet nem meghatározó tanulmányokban a vizsgálatok 25\%-a bizonyította az OA-publikáláshoz kapcsolódó idézettségi előnyt. A vizsgálati minta 
heterogenitása miatt a metaanalízis készítése nem volt lehetséges. Különbségek mutatkoztak az alkalmazott módszerekben és mutatókban is. A jövőbeli tanulmányoknak be kell számolniuk legalább az OA módjáról, az OA és nem OA-publikációk számáról, a felhasznált adatok összehasonlíthatóságáról, az időkeretről (idézési ablak), egy közös mutatóról (pl. medián idézettség publikációnként), valamint a zavaró tényezők és azok kezelésének módjáról ahhoz, hogy megbízható és reprodukálható eredmények szülessenek.

\section{ANYAg és módszer}

A hazai tudományos kibocsátásban feltételezett OA-előny empirikus megközelítéséhez a Web of Science (WoS) adatbázisaiban nyilvántartott, legalább egyszeresen magyar intézményhez affiliált közleményeket tekintettük vizsgálati populációnak. Az adatgyüjtést az 2014-2018 közötti ötéves periódusra korlátoztuk, több megfontolás alapján: egyrészt az ötéves időszakasz sztenderd vizsgálati egységnek tekinthető az értékelő tudománymetriában, másrészt ez a legközelebbi olyan időszak, amelynek záróévétől számítottan legalább három év eltelt. Utóbbi azért fontos, mert a szakmai konszenzus értelmében a legtöbb területen minimálisan a közléstől számított három év szükséges a jellemző idézettségi ráta beállásához, amelyre megbízható és összemérhető idézettségi statisztikák alapozhatók. A végső minta $n=45440$ közleményt tartalmazott.

Az idézettségi előny és az OA-státusz kapcsolatának tesztelése céljából egyrészt a mintában szereplő közlemények mindegyikére egy olyan idézettségmutatót alkalmaztunk, amely az idézettségi hatást összemérhető módon fejezi ki heterogén, tudományterületileg, közlési év stb. tekintetében változatos mintában is. Másrészt a hazai közleménymintát három további indikátor- vagy változószettel jellemeztük. A három csoport azokat a tényezőket gyűjti össze, amelyek a szakmai konszenzus értelmében jelentős hatást gyakorolnak az idézettség alakulására (Tahamtan et al. 2016), köztük a kérdéses, OAstátuszt, illetve besorolást kódoló változókkal. Ezekre a változókra/ 
mutatókra az alábbiakban az idézettségi tényező/faktor terminussal hivatkozunk. Ez a mozzanat alapvető fontosságú elemzéseink szempontjából, hiszen egyik kutatási kérdésünk arra vonatkozik, hogy az OA-közlemények feltételezett idézettségi előnye vagy viselkedése mennyiben tulajdonítható az OA-státusznak, mennyiben pedig más közleményjellemzőknek. Ez utóbbi kérdés pedig az OA-státusz és a további idézettségi tényezők kapcsolatának feltárásával válaszolható meg, ami az idézettségre gyakorolt hatásukat illeti. Az alkalmazott hatásmutató, illetve a három változószett és azok tagjai az alábbiak.

- Idézettségi hatás. Az közlemények idézettségi hatásának mérésére az ún. Normalizált Idézettségi Rátát (Normalized Citation Score, NCS) alkalmaztuk, amely minden publikáció idézetszámát annak tudományterületén és közlési évében megjelent publikációk nemzetközi idézettségi átlagához viszonyítja. Értéke $1(>1,<1)$, ha a közlemény idézettsége megfelel a nemzetközi átlagnak (magasabb, illetve alacsonyabb annál).

- Tudományterületi besorolást kódoló változók. A tudományterületi hatás mérésére bevezetett, az Essential Science Indicators (ESI) tudományterületi felosztására épülő 22-elemű változószett. A kétértékű („dummy”) változók a közlemény valamely ESItudományterülethez való hozzátartozását fejezik ki ( 1 = a közlemény a területhez tartozik, 0 = a közlemény más területhez tartozik).

- Folyóiratrangot, nemzetköziességet és társszerzőséget kódoló változók. A legfontosabb idézettségi tényezők mutatói, ugyancsak többnyire kétértékű változókkal: (1) a közlő folyóirat szakterületi rangsorban elfoglalt helye, kvartilis-besorolása (Q12: az l-es vagy 2-es kvartilishez tartozó közlemény, Q34: a 3-as vagy 4-es kvartilishez tartozó közlemény), (2) nemzetközi társszerzőségben készült közlemény (INT, értéke 1 = nemzetközi, 2 = hazai szerzőség vagy társszerzőség), illetve (3) a szerzőszám (CoAU), utóbbi értéke megnevezésével összhangban a közlemény szerzőinek számával egyezik meg.

- OA-státuszt kódoló változók. A közlemény OA-státuszát rögzítő három dummy változó a következő (célszerű volt egyetlen háromértékű változó helyett minden OA-státuszhoz külön 
változót definiálni a részletes modellvizsgálatok kivitelezhetősége érdekében): NemOA (1 = a közlemény nem nyílt hozzáférésű), GoldOA ( $1=$ a közlemény Gold OA státusú), illetve only.green ( 1 = a közlemény Green OA státuszú, de további OA-státusza, pl. Gold, nincsen). További OA-változatokat egyelőre nem vettünk figyelembe.

A mintából létrehozott, fentiek szerint kialakított adatbázison az alábbi elemzéseket végeztük el:

(1) Leíró jellegű analízis révén összehasonlítottuk a különböző OAstátuszú közleménykörök tudományos hatását.

(2) Szintén leíró, kereszttáblás elemzések révén megvizsgáltuk az OA-státusz, illetve a további idézettségi tényezők összefüggését, interakcióit az idézettségre gyakorolt hatás tekintetében.

(3) $\mathrm{Az}$ OA-státusznak a tudományos hatás mértékére gyakorolt befolyását a többi idézettségi tényezőtől elkülönítendő, regresszióanalízis formájában az idézettség mértékét magyarázó modellt állítottunk fel. Ennek kiértékelése lehetőséget nyújtott az OA-státusz hozadékának számszerű becslésére, illetve a többi tényező szerepével való számszerű összevetésére.

$\mathrm{Az}$ egyes elemzések további módszertani részleteit az Eredmények vonatkozó részében, azokkal összefüggésben mutatjuk be.

\section{EREDMÉNYEK}

A hazai kibocsátás OA-státusz szerinti alapmegoszlásait tekintve a nyílt hozzáférésű publikációs utak egyértelműen előnyös helyzetet eredményeznek (2. táblázat). A vizsgált időszak OA-kibocsátása - az összes OA-utat figyelembe véve - hozzávetőleg azonos méretű, illetve részarányú, mint a nem nyílt hozzáférésű frakció. Ebből adódóan a két kör átlagos idézettségi mutatói jól összevethetők, amelyek pedig az OA-kör fölényét támasztják alá. Közelebbről, az OA-közlemények átlagos normalizált idézettsége (MNCS) közel kétszer akkora, mint 
a nem-OA közleményeké - illetve, mint a nemzetközi átlag. Az ún. átlagos percentilis mutatója értelmében pedig az OA-frakcióhoz tartozó közlemények jellemzően a tudományterület idézettségi rangsorának felénél, míg a nem-OA közlemények a harmadánál foglalnak helyet.

2. táblázat: A vizsgált hazai kibocsátás mennyiségi és idézettségi mutatói OA-státusz szerint

\begin{tabular}{lrr}
\hline & OA & Nem-OA \\
Közleményszám & 21663 & 23777 \\
MNCS & 1.72 & 1.01 \\
Átlagos percentilis & 50.22 & 33.41 \\
\hline
\end{tabular}

Az idézettségi tényezók és az OA-státusz hatásának kapcsolata - interakciók

A fent leírt általános kép hátterének, illetve esetleges torzításainak feltárását célozza annak vizsgálata, hogy az OA-státusz idézettségre gyakorolt hatása milyen összefüggést mutat az idézettséget befolyásoló további változókkal (idézettségi faktorokkal) a hazai mintán belül. $\mathrm{Az}$ alábbiakban a három legfontosabb idézettségi faktor, a tudományterület, a folyóiratrang, illetve a nemzetköziesség mutatóival feltárt interakciókat ismertetjük.

A hazai kibocsátás eltérő OA-státuszú csoportjainak idézettségi hatását mutatja be az l. ábra tudományterületi bontásban - vagyis a tudományterületi besorolás, illetve az OA-státusz hatásának összefüggését jeleníti meg. A kimutatás tanúsága szerint (1) az OAelőny tudományterület-függő, amennyiben a három görbe (NemOA, Green-OA, Gold-OA) korántsem párhuzamosan fut, illetve rendszeresen keresztezi is egymást: az idézettség OA-státuszok közti arányai területenként változnak. Ugyanakkor az is jól látható, hogy (2) a nyílt hozzáférésű közlemények csaknem minden területen magasabb átlagos idézettséget érnek el, mint a nem OA-közlemények, tekintve, hogy a „Nem-OA” görbe jórészt az OA-görbék alatt fut. A részleteket a 3. táblázat mutatja be: az ábrán is könnyen azonosítható egy-két terület, 
ahol az OA-státusz előnye nem mutatkozik meg, vagy egyenesen kevésbé látszik előnyösnek, a mérnöki tudományok (Engineering) és az anyagtudományok (Materials Science). Másrészt, jelentős előnyt élvez a „Gold” út a fizika és űrtudományok terén (Physics, Space Science). A „Green” út előnye többszörösen felülmúlja a másik két OA-státuszt a klinikai orvostudomány és a molekuláris biológia területén (Clinical Medicine, Molecular Biology and Genetics). Figyelemre méltó, hogy a „Green” útnak megfelelő görbe az esetek többségében a „Gold”-görbe felett halad, a leginkább ígéretes OA-státuszként feltüntetve ezt a módozatot (ezt a megfigyelést támogatja a regressziós eredményekről szóló szakasz is).

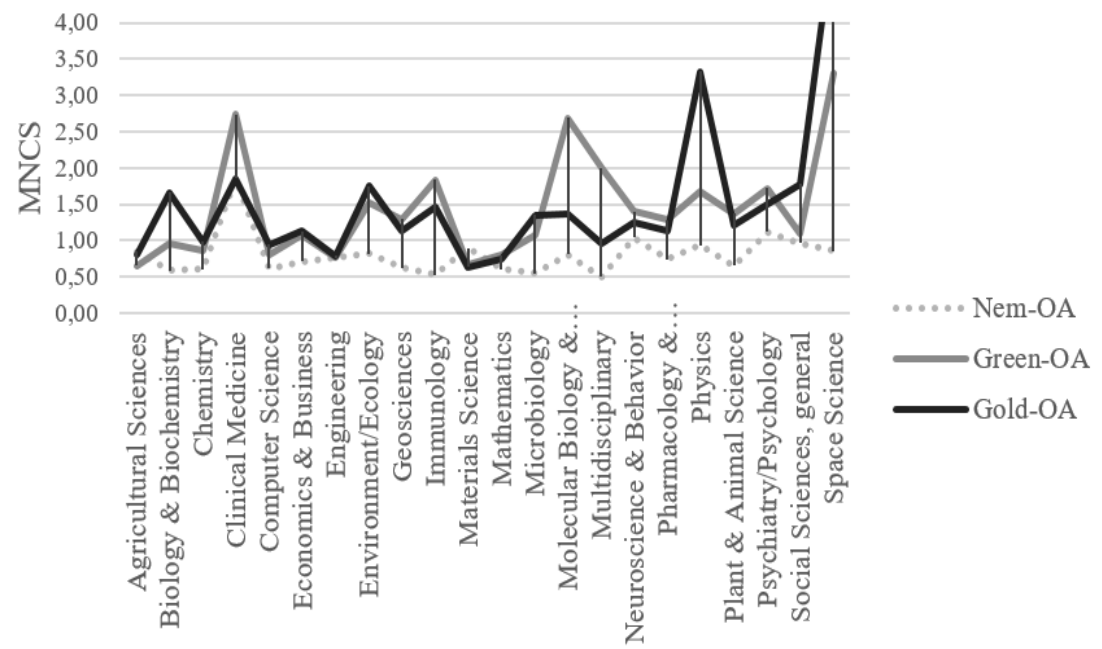

Tudományterület (ESI)

1. ábra: A tudományterületi besorolás és az OA-státusz interakciója a vizsgált hazai mintában 
3. táblázat: A vizsgált hazai kibocsátás átlagos normalizált idézettsége (MNCS) tudományterületek és OA-státusz szerint

\begin{tabular}{lrrr}
\hline Tudományterület (ESI) & Nem-OA & Green & Gold \\
Agricultural Sciences & 0.85 & 0.65 & OA \\
Biology \& Biochemistry & 0.59 & 0.97 & 1.67 \\
Chemistry & 0.61 & 0.87 & 0.98 \\
Clinical Medicine & 1.86 & 2.74 & 1.85 \\
Computer Science & 0.61 & 0.81 & 0.95 \\
Economics \& Business & 0.71 & 1.07 & 1.13 \\
Engineering & 0.77 & 0.76 & 0.79 \\
Environment/Ecology & 0.82 & 1.52 & 1.75 \\
Geosciences & 0.63 & 1.30 & 1.14 \\
Immunology & 0.53 & 1.84 & 1.47 \\
Materials Science & 0.90 & 0.68 & 0.64 \\
Mathematics & 0.60 & 0.80 & 0.74 \\
Microbiology & 0.55 & 1.07 & 1.35 \\
Molecular Biology \& Genetics & 0.81 & 2.69 & 1.37 \\
Multidisciplinary & 0.50 & 2.00 & 0.96 \\
Neuroscience \& Behavior & 1.04 & 1.40 & 1.26 \\
Pharmacology \& Toxicology & 0.75 & 1.29 & 1.14 \\
Physics & 0.94 & 1.68 & 3.33 \\
Plant \& Animal Science & 0.66 & 1.37 & 1.20 \\
Psychiatry/Psychology & 1.12 & 1.72 & 1.50 \\
Social Sciences, general & 0.96 & 1.10 & 1.78 \\
Space Science & 0.85 & 3.29 & 5.23 \\
\hline
\end{tabular}


A következő kiemelt idézettségi faktor a folyóiratrang, vagyis a közlő folyóiratok elhelyezkedése a szakterületi rangsorban (kvartilisekben, JIF alapján). A kvartilis-besorolás és az OA-státusz hatásának mintabeli interakcióját szemlélteti az 2. ábra. Az interakció jelensége itt is szembeötlő: (1) a három OA-kategóriában eltérő meredekséggel változik, növekszik az átlagos idézettségi hatás a 3-4. kvartilisbe tartozó közlemények köréből átlépünk az 1-2. kvartilisbe tartozó közlemények körébe. Továbbra is igaz viszont, hogy (2) a Nem-OA publikációk mindkét körben alacsonyabb átlagos hatást váltanak ki, mint akár a Green-, akár a Gold-OA publikációk. A tudományterületekre kapott eredményekkel az is összhangban áll, hogy a „Green” út itt is feltűnően sok hozadékkal kecsegtet: a részleteket közlő 4. táblázat számszerűen is tanúsítja, hogy míg a 3-4. kvartilisben a Green és a nem nyílt hozzáférésű közlemények átlagos hatása lényegében azonos (kb. 0.4), addig az 1-2. kvartilisben a Green-OA kör ennek öt-hatszorosát (2.2), míg a NemOA kör a háromszorosát éri el (1.33). Ezzel a Green utas közlemények még a Gold OA-kör hatását is enyhén felülmúlják.

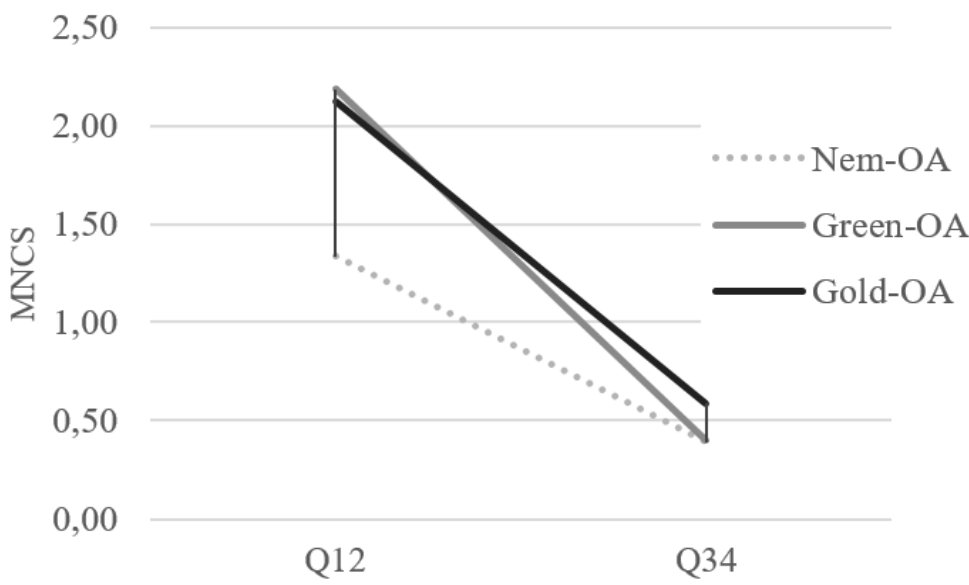

Folyóiratrang

2. ábra: A folyóiratrang és az OA-státusz interakciója a vizsgált hazai mintában 


\begin{tabular}{lrrrr} 
4. táblázat: & \multicolumn{2}{l}{$\begin{array}{l}\text { A vizsgált hazai kibocsátás átlagos normalizált } \\
\text { idézettsége (MNCS) folyóiratrang és OA-státusz } \\
\text { szerint }\end{array}$} \\
$\begin{array}{l}\text { Felső 50\% } \\
\text { Nem-Q12 }\end{array}$ & Q12 & Alsó 50\% \\
Nem-OA & 0.38 & 1.33 & 1.29 & 0.39 \\
Green-OA & 0.42 & 2.18 & 2.17 & 0.40 \\
Gold-OA & 0.67 & 2.12 & 2.09 & 0.59 \\
\hline
\end{tabular}

A harmadik tényező, amely a vonatkozó szakirodalom szerint jelentős hatást gyakorol az idézettségre, a nemzetközi társszerzőség, nemzetköziesség. Ennek a mutatónak az OA-státusszal adódott interakcióját szemlélteti az 3. ábra. A kimutatás lényegében megismétli az iménti, a folyóiratrangra vonatkozó eredményeket. (1) Az interakció látványos, az egyes OA-kategóriákban a nemzetköziesség eltérő mértékben növeli az átlagos hatást, de(2)a Nem-OAtípusú közlemények megint mindkét esetben (nemzetközi, nem nemzetközi) alacsonyabb hatást váltanak ki átlagosan. A három OA-státusz ugyanúgy látszik reagálni a nemzetköziesség tényezőjére, ahogyan a folyóiratrang mutatójára: a Green út a nemzetközies kategóriában megötszörözi a hatást (a nem-nemzetközihez képest), míg a Nem-OA út „csupán” megháromszorozza, illetve ezzel a Green-OA nemcsak az Nem-OA, hanem a Gold-OA hozadékát is felülmúlja (5. táblázat). 


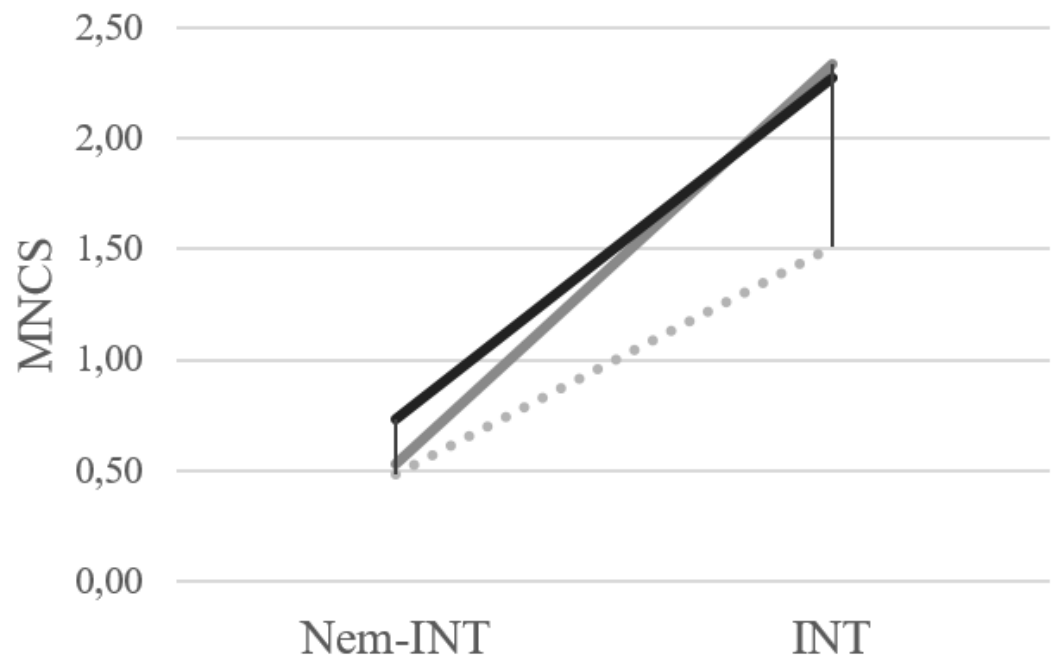

Nemzetközi társszerzőség

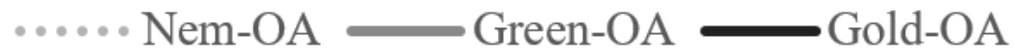

3. ábra: A nemzetköziesség és az OA-státusz interakciója a vizsgált hazai mintában

5. táblázat: A vizsgált hazai kibocsátás átlagos normalizált idézettsége (MNCS) nemzetköziesség és OA-státusz szerint

\begin{tabular}{lrr}
\hline & Nem-INT & INT \\
Nem-OA & 0.48 & 1.51 \\
Green-OA & 0.53 & 2.34 \\
Gold-OA & 0.73 & 2.27 \\
\hline
\end{tabular}

Az OA-státusz önálló hatása az idézettségre - interferenciák

Vizsgálatunk elsődleges kérdése, hogy a hazai kibocsátás vonatkozásában azonosítható-e a nyílt hozzáférésnek tulajdonítható előny az idézettségre nézve, és ha igen, ez milyen mértékű. 
Az utóbbi részkérdés megválaszolásához az előző szakaszban feltárt interakciókon túl ki kell szűrnünk az ún. interferenciákat is az idézettségi hatás magyarázatában, vagyis azt szükséges kimutatnunk, hogy mennyiben magyarázza a megfigyelhető idézettséget az OAstátusz, ha a hatását elkülönítjük a többi változótól, azaz az idézettséget befolyásoló tényezőktől. Ennek elterjedt módszere a regresszióanalízis, a magyarázó változók (itt: idézettségi faktorok, köztük az OA-mutatók) önálló hatásának kimutatása a magyarázott változóra (itt: az normalizált idézettségre).

A hazai mintára vonatkozó regresszióanalízis során a következő modellt építettük fel. A magyarázó változók között a kibocsátás mutatóinak fentiekben leírt három csoportját szerepeltettük: (1)A tudományterületi kategóriákat, (2) Az idézettségi hatás legfontosabb további tényezőit, amely csoport a szerzőszám, a folyóiratrang és a nemzetköziesség mutatóit foglalta magában, illetve (3) a számunkra kérdéses, OAstátuszt leíró változószettet ( $\mathrm{Non} \mathrm{OA}$, GoldOA, only.green). A kezdeti modellt a lehető legjobb illeszkedés biztosítása érdekében teszteltük: az ún. modellszelekciós eljárás egyrészt az összes felsorolt mutató beválasztását igazolta, másrészt, dacára a fent bemutatott interakcióknak, a mutatók interakcióját rögzítő további változók beemelését nem támogatta (az illeszkedés nem javult az eredeti modellhez képest). Az eredmények értelmezéséhez fontos megjegyzés, hogy a célváltozót, a normalizált idézettségi hatás (NCS) mutatóját szokásosan átalakítva, az értékek logaritmusát véve foglaltuk a modellbe, amellyel az erősen ferde eloszlású változóból a lineáris többszörös regresszió követelményeinek megfelelő normál eloszlású változót hoztunk létre („log-normálás”). Mindezek nyomán a végső modellt leíró regressziós egyenlet az alábbi kompakt formát öltötte:

$$
b_{0}+\sum_{n} b_{T(n)} T(n)+\sum_{m} b_{I(m)} I(m)+\sum_{u} b_{O A(u)} O A(u)=\ln N C S
$$


ahol

- $T_{(\mathrm{n})}$ az ESI tudományterületeket kódoló kétértékű változók sorozata $(n=22)$,

- $I_{(\mathrm{m})}$ az idézettségi faktorok sorozata, vagyis a coAU, Int, Q12 változók háromtagú együttese $(m=3)$,

- $\mathrm{OA}_{(\mathrm{u})}$ az OA-státuszt reprezentáló indikátorok, vagyis a NonOA, GoldOA, only.green változók háromtagú csoportja $(u=3)$.

A regressziós eljárás eredményeit a 6. táblázat foglalja össze. A táblázat a fentiek szerint csoportosított magyarázó változók, idézettségi faktorok becsült együtthatóját, vagyis önálló hatásának mértékét ismerteti (azok további sztenderd statisztikai jellemzőivel együtt). A tábla végén a modell érvényességét, illeszkedésének mértékét kifejező paraméterek szerepelnek. Ezek közül kiemelendő az R-négyzet relatíve magas értéke $\left(R^{2}>0.5\right)$, amely érték a társadalomtudományi modellek körében kifejezetten szorosnak tekinthető illeszkedést közvetít, azaz a kapott egyenlet igen jól magyarázza a tényleges idézettségeket.

$\mathrm{Az}$ együtthatókat (b-értékeket) tekintve megállapítható, hogy a nyílt hozzáférés önállóan is növeli a közlemények normalizált idézettségét. Közelebbről, míg a Nem-OA kategória becsült együtthatója negatív előjelű, azaz hozzájárulása a várható idézettséghez negatív, addig mindkét OA-kategória (GoldOA, only.green) pozitív előjellel, illetve hozzájárulással rendelkezik. Ugyanakkor mind a negatív, mind a pozitív hatások mértéke kicsi, különösen, ha összevetjük a többi idézettségi faktor hatásával. A nemzetköziesség és a folyóiratrang (illetve néhány tudományterületi kategória) elkülönített hatása többszöröse az OA-státusz idézettségi szorzójának. Az OA-státuszok közül ismét kiemelkedik azonban a Green út: önálló hatása felülmúlja a Gold út és a nem-OA közlés idézettségre gyakorolt befolyásának mértékét. (A regressziós tábla vonatkozásában célszerű megjegyezni, hogy a szignifikanciaszintek feltüntetése ebben az esetben jórészt formalitás - valódi jelentése vizsgálatunkban az együtthatóknak, vagyis az egyes változókhoz tartozó hatásméretnek van). 
6. táblázat: A regresszió eredményei

\begin{tabular}{lrrrrrr}
\hline Magyarázó változó & $\begin{array}{c}\text { együttható } \\
\text { (b) }\end{array}$ & $\begin{array}{c}\text { standard } \\
\text { együttható } \\
\text { (beta) }\end{array}$ & $\begin{array}{c}\text { Std. } \\
\text { Error }\end{array}$ & $\operatorname{Pr}(>|t|)$ & Sig \\
\hline coAU & 0.00 & 0.16 & 0.00 & 0 & $0 . * * *$
\end{tabular}

Tudományterület

Agricultural

Sciences

0.18

0.03

0.02

8.40694E-18

Biology \&

Biochemistry

0.09

0.03

$0.01 \quad$ 1.63545E-09

Chemistry

0.11

0.05

0.01

4.31037E-16

Clinical Medicine

0.20

0.12

0.01

1.92485E-63

Computer Science

0.10

0.01

0.02

4.56154E-05

Economics \&

Business

0.20

0.03

0.03

6.50208E-15

Engineering

0.18

0.05

0.01

8.96867E-34

Environment/

Ecology

0.23

0.05

0.02

6.8117E-36

Geosciences

0.17

0.03

$0.02 \quad 5.76652 \mathrm{E}-19$

Immunology

0.07

0.01

0.02

0.000665231

Materials Science

0.07

0.01

$0.02 \quad 0.001237296$

Mathematics

0.17

0.05

0.02

9.75336E-29

Microbiology

0.22

0.03

0.02

3.22963E-21

Molecular Biology

\& Genetics

0.13

0.03

0.02

6.58871E-12

Multidisciplinary

0.21

0.01

0.06

$0.00062357^{* * *}$

Neuroscience \&

Behavior

0.15

0.04

0.02

1.75229E-20 


\begin{tabular}{|c|c|c|c|c|c|}
\hline Magyarázó változó & $\begin{array}{l}\text { együttható } \\
\text { (b) }\end{array}$ & $\begin{array}{c}\text { standard } \\
\text { együttható } \\
\text { (beta) }\end{array}$ & $\begin{array}{l}\text { Std. } \\
\text { Error }\end{array}$ & $\operatorname{Pr}(>|t|)$ & Sig \\
\hline $\begin{array}{l}\text { Pharmacology \& } \\
\text { Toxicology }\end{array}$ & 0.13 & 0.03 & 0.02 & 4.68273E-16 & $* * *$ \\
\hline Physics & 0.10 & 0.04 & 0.01 & $2.07035 \mathrm{E}-11$ & $* * *$ \\
\hline $\begin{array}{l}\text { Plant \& Animal } \\
\text { Science }\end{array}$ & 0.22 & 0.07 & 0.01 & 1.62147E-50 & $* * *$ \\
\hline $\begin{array}{l}\text { Psychiatry/ } \\
\text { Psychology }\end{array}$ & 0.19 & 0.04 & 0.02 & 4.11331E-23 & $* * *$ \\
\hline $\begin{array}{l}\text { Social Sciences, } \\
\text { general }\end{array}$ & 0.24 & 0.06 & 0.02 & $1.08324 \mathrm{E}-49$ & $* * *$ \\
\hline Space Science & 0.15 & 0.03 & 0.02 & $2.71863 \mathrm{E}-13$ & $* * *$ \\
\hline \multicolumn{6}{|l|}{$\begin{array}{l}\text { Nemzetköziesség, } \\
\text { presztizs }\end{array}$} \\
\hline HUN.int & 0.23 & 0.22 & 0.01 & 0 & $* * *$ \\
\hline HUN.Q12 & 0.26 & 0.28 & 0.01 & 0 & $* * *$ \\
\hline \multicolumn{6}{|l|}{ OA-státusz } \\
\hline HUN.NonOA & -0.08 & -0.07 & 0.01 & $1.02662 \mathrm{E}-13$ & $* * *$ \\
\hline HUN.GoldOA & 0.08 & 0.05 & 0.01 & $1.37766 \mathrm{E}-12$ & $* * *$ \\
\hline only.green & 0.10 & 0.06 & 0.01 & 9.17531E-18 & $* * *$ \\
\hline \multicolumn{6}{|l|}{ Modell-illeszkedés } \\
\hline R-négyzet & 0.54 & & & & \\
\hline Korrigált R-négyzet & 0.54 & & & & \\
\hline F-próba értéke & 1872.00 & & & & \\
\hline $\mathrm{p}<$ & 0.00 & & & & \\
\hline
\end{tabular}




\section{DisZKuSSZIó ÉS KÖVETKEZTETÉSEK}

A fenti elemzésekkel fó célunk az volt, hogy a hazai kibocsátás egy időben jól körülhatárolt szegmensére nézve megvizsgáljuk a nyílt hozzáférésű publikálás általánosan posztulált idézettségi előnyét. Vizsgálatunk lépcsőzetesen építkezett, ennek során igyekeztünk az OA-alapstatisztikáktól elmozdulva módszeresen elválasztani egymástól az idézettségre befolyással bíró tényezők szerepét, ilyen módon pedig elkülöníteni és felmérni az OA-státusz tényleges, önálló hozzájárulását a közlemények tudományos hatásához.

A vizsgálatok alapján megállapíthatjuk, hogy az OA-típusú publikációs utak hazai viszonylatban (vagyis a hazai kibocsátás tekintetében) is idézettségi előnnyel rendelkeznek a nem-OA típusú úthoz képest. Az alapstatisztikák ezt az előnyt egyértelműen közvetítik, ahol az OA-kategóriák számottevő idézettségi fölényt élveznek. A részletes vizsgálatok szintén megerősítik, hogy az előny létezik. Az OA-státusz és az idézettséget befolyásoló legfontosabb tényezők összefüggésének (interakciójának) elemzése során láthatóvá vált, hogy a nyílt utak a többi változó (folyóiratrang, nemzetköziesség, szakterület) minden - vagy majdnem minden - értéke mellett magasabb átlagos idézettségi hatást váltanak ki. Az OA önálló, a többi tényező hatásától függetlenített szerepét feltáró regresszió pedig egyértelmű pozitív hozzájárulást tulajdonított az OA-kategóriáknak a tudományos hatás mértékére nézve. Külön kiemelendő, fontos eredmény a Green OA „teljesítménye”, amely minden elemzés szerint meghaladja a Gold és a Nem-OA hozzájárulását.

A fenti summázat ugyanakkor az éremnek csak az egyik oldala. Vizsgálatunk céljait tekintve talán ennél is fontosabb eredmény, hogy az alapstatisztikák tudósította képet jelentősen árnyalják a részletes elemzések, mégpedig az idézettségi előny OA-státuszhoz köthető mértékét tekintve. Az OA-hozzájárulás mértéke, amely az alapstatisztikák értelmében számottevő, jóval szerényebbnek adódik, ha az idézettségi előnyt felbontjuk annak tényezői (köztük az OA-státusz) 
szerint. Egyfelől, az interakciók vizsgálata megmutatta, hogy a többi idézettségi faktor - elsősorban a folyóiratrang és a nemzetköziesség - értékeinek változása (pl. a Q1-Q2 kategóriába, vagy a nemzetközi együttműködésben készült közlemények körébe való átlépés) jelentősen módosítja (növeli) az átlagos idézettséget, jóval nagyobb mértékben, mint a nem-OA körben. Ezzel összhangban az OA elkülönített szerepét jellemző regressziós együtthatók értéke is igen csekély, összehasonlítva, megintcsak, a másik két legfontosabb mutatóéval (Q12, INT). Számszerű példát tekintve modellünk alapján: ha egy nemzetközi átlagnak megfelelő idézettségü $(N C S=1)$ nem-OA közleménynek csupán egyetlen paraméterét, az OA-státuszát változtatjuk (elméletben), mégpedig úgy, hogy GoldOA-közlemény legyen, akkor a GoldOA-státusz önálló hatását kifejező becsült együttható $(b=0.08)$ alapján jósolt idézettsége NCS $=1$ helyett NCS = 1.08 lesz. Másként fogalmazva, az OA-státusz 8\%-os növekményt jósol a (normalizált) idézettségben, a világátlaghoz képest ebben a speciális esetben (1-től különböző NCS-értékek esetén ez az összefüggés nem ennyire egyszerű, emlékezzünk rá, hogy az egyenletben az NCS-értékek logaritmusával számolunk).

A fentieket összegezve elmondható, hogy az eredmények óvatos optimizmusra adnak indokot az OA-közlés hazai hozadékát illetően, ami a tudományos hatást illeti. Vizsgálataink alátámasztják, hogy ha a nagyhatású idézettségnövelő tényezőknél kevésbé meredeken is, de a nyílt hozzáférés is hozzáad a várható akadémiai elismeréshez. Ami azonban talán még ennél is lényegesebb, a fenti megközelítés rávilágít annak fontosságára, hogy az OA-előnyök empirikus azonosítása során túllépjünk az alapvető összefüggéseken és egyszerű statisztikai összehasonlításokon (pl. az OA- és a nem-OA közlemények idézettsége között), és igyekezzünk a tudományos kommunikáció és információ ökoszisztémájának teljesebb kontextusában elhelyezni a kérdést, hogy hitelesebb képet kapjunk ennek a kiemelten fontos kérdéskörnek a jellemzőiről. 


\section{IRODALOMJEGYZÉK}

Aman 2014

Aman, V., Is there any measurable benefit in publishing preprints in the arXiv section Quantitative Biology?, arXiv preprint arXiv:

https://arxiv.org/1411.1955, 2014.

Anderson 2013

Anderson, B. R., Funding sources of impactful and transformative research, San Jose State University, 2013.

Atchison \& Bull 2015

Atchison, A., Bull, J., Will open access get me cited? An analysis of the efficacy of open access publishing in political science, PS: Political Science \& Politics, 48(1), 2015, 129-137. https://doi.org/10.3917/polaf.137.0129

Craig et al. 2007

Craig, I. D., Plume, A. M., McVeigh, M. E., Pringle, J., Amin, M., Do open access articles have greater citation impact?: a critical review of the literature, Journal of Informetrics, 1(3), 2007, 239-248.

https://doi.org/10.1016/j.joi.2007.04.001

Davis 2011

Davis, P. M., Open access, readership, citations: a randomized controlled trial of scientific journal publishing, The FASEB journal, 25(7), 2011, 2129-2134. https://doi.org/10.1096/fj.11-183988

Evans \& Reimer 2009

Evans, J. A., Reimer, J., Open access and global participation in science, Science, 323(5917), 2009, 1025. https://doi.org/10.1126/science.1154562

Eysenbach 2006

Eysenbach, G., Citation advantage of open access articles, PLoS biology, 4(5), 2006, e157. https://doi.org/10.1371/journal.pbio.0040157

Gentil-Beccot et al. 2010

Gentil-Beccot, A., Mele, S., Brooks, T., Citing and reading behaviours in high-energy physics, Scientometrics, 84(2), 2010, 345-355.

https://doi.org/10.1007/s11192-009-0111-1 
Hajjem et al. 2006

HajJem, C., Harnad, S., Gingras, Y., Ten-year cross-disciplinary comparison of the growth of open access and how it increases research citation impact, arXiv preprint https://arxiv.org/abs/cs/0606079, 2006.

Kousha \& Abdoli 2010

Kousha, K., Aвdoli, M., The citation impact of Open Access agricultural research: A comparison between $\mathrm{OA}$ and non-OA publications, Online Information Review, 2010.

Langham-Putrow et al. 2021

Langham-Putrow, A., Bakker, C., Riegelman, A., Is the open access citation advantage real? A systematic review of the citation of open access and subscription-based articles, PLOS ONE, 16(6), 2021, e0253129.

https://doi.org/10.1371/journal.pone.0253129

Lawrence 2001

LAWRENCE, S., Free online availability substantially increases a paper's impact, Nature, 411(6837), 2001, 521. https://doi.org/10.1038/35079151

McCabe \& Snyder 2014

McCabe, M. J., Snyder, C. M., Identifying the effect of open access on citations using a panel of science journals, Economic inquiry, 52(4), 2014, 1284-1300. https://doi.org/10.1111/ecin.12064

Sahu et al. 2005

Sahu, D. K., Gogtay, N. J., Bavdekar, S. B., Effect of open access on citation rates for a small biomedical journal, 2005.

Swan 2010

Swan, A., The Open Access citation advantage: Studies and results to date. Technical Report. School of Electronics \& Computer Science, University of Southampton, 2010

Tahamtan et al. 2016

Tahamtan, I., Afshar, A. S., Ahamdzadeh, K., Factors affecting number of citations: a comprehensive review of the literature, Scientometrics, 107(3), 2016, 1195-1225. https://doi.org/10.1007/s11192-016-1889-2 
The Working Group on Rewards under Open Science. Evaluation of research careers and fully acknowledging open science practices, Luxembourg, Publications Office of the European Union, 2017. https://doi.org/10.2777/75255

Wagner 2010

Wagner, A. B. (2010). Open access citation advantage: An annotated bibliography. Issues in science and technology librarianship, 60(2)

Wang et al. 2015

Wang, X., Liu, C., MaO, W., FAng, Z., The open access advantage considering citation, article usage and social media attention, Scientometrics, 103(2), 2015, 555-564. https://doi.org/10.1007/s11192-015-1547-0

Wohlrabe \& Birkmeier 2014

Wohlrabe, K., Birkmeier, D., Do open access articles in economics have a citation advantage?, 2014.

Xu et al. 2011

Xu, L., Liu, J., FAng, Q., Analysis on open access citation advantage: an empirical study based on Oxford open journals = Proceedings of the 2011 iConference, 2011, 426-432. https://doi.org/10.1145/1940761.1940819

\section{Zhang 2006}

ZHANG, Y., The effect of open access on citation impact: a comparison study based on web citation analysis, 2006. https://doi.org/10.1515/LIBR.2006.145

Zhao 2010

Zнао, D., Characteristics and impact of grant-funded research: a case study of the library and information science field, Scientometrics, 84(2), 2010, 293-306. 


\section{A KÖZÖSSÉGI TUDOMÁNY}

\section{GAÁlnÉ KALYdy DÓRA}

Az Open Science (nyílt tudomány) mozgalom egyre nagyobb teret hódít magának. Míg pár éve még csak a nyílt hozzáférésről beszéltünk (2002, Budapest Open Access Initiative), ma már szerte a világon nyílt tudományról van szó, melynek csupán egy szelete a nyílt hozzáférés. A LIBER ${ }^{1}$ (Association of European Research Libraries) 2021. éves konferenciáján ${ }^{2}$ az előadások és workshopok 55\%-a nyílt tudományhoz kapcsolódtak. Aplenáris előadások szintén a nyílt tudomány témakörben mutattak be újabb és újabb lehetőségeket. A 2019-es konferencián alakult Citizen Science munkabizottság ${ }^{3}$ is bemutatta az elmúlt két év munkáját, a szakkönyvtárak, egyetemi könyvtárak Citizen Science-ben, azaz a közösségi tudományban betöltött szerepét és lehetőségeit és a jó gyakorlatok mentén igyekszik útmutatót adni a könyvtáraknak.

Izgalmas, kérdésekkel teli témának tűnik a közösségi tudomány. A Citizen Science fordítása/magyarosítása nem egyszerű, hiszen a „citizen” állampolgárt jelent, de az „állampolgári vagy polgári tudomány, tudományosság" nem adja vissza azt a frappáns angol kifejezést, mely arra utal, hogy egy tudományos kutatásban nem hivatásos kutatók is, azaz elkötelezett és érdeklődő amatőrök hatékonyan vesznek részt. Az amatőr szó a magyar nyelvben pejoratív értelemmel bír, ezért én magam inkább a közösségi tudomány kifejezést használom.

Mivel Magyarországon hivatalos dokumentumokban nem rögzítették, hogy pontosan mi is a közösségi tudomány, ezért kiindulási pontnak

1 LIBER (Association of European Research Libraries) honlapja: https://libereurope.eu/ (utolsó megtekintés: 2021. 07. 02.)

2 LIBER 2021 ONLINE: https://liberconference.eu/home-2/liber-2021programme/ (utolsó megtekintés: 2021. 07. 02.)

3 LIBER stratégia: https://libereurope.eu/strategy/innovative-scholarlycommunication/citizenscience/ (utolsó megtekintés: 2021. 07. 02.) 
tekintsük a University College London által kiadott Citizen Science ${ }^{4}$ könyvben megfogalmazottakat, mely hivatkozik az Európai Bizottság meghatározására is ${ }^{5}$. Ennek értelmében a közösségi tudomány olyan tudományos munka, melyben részt vesznek a közösség tagjai is, szakemberek és tudományos intézmények irányítása alatt. Ezt a meghatározást az Európai Bizottság mára már kibontotta, megmagyarázta ${ }^{6}$.

Kötetünkben a nyílt tudomány különböző részeiről már részletesen írtunk. A közösségi tudomány a legfrissebb eleme a szerteágazó nyílt tudománynak, mindenképpen fontos szerepet játszik a tudomány társadalmasításában, az elefántcsont-toronyban lévő tudomány közelebb kerül az átlagemberekhez a nyílt hozzáféréseken és a szabad információkon keresztül. Azáltal, hogy az átlagember részt vállal egy tudományos programban, sok esetben felelősebb és tudatosabb állampolgár lesz. Biztosan igaz az az állítás is, hogy azoknak a tudósoknak, akik hosszú időt töltenek ilyen tevékenységgel, átalakul a beszédmódjuk, és - ez alapvető félelmük is - lassan egyszerűsödik a gondolkodásuk, és elveszítik újító erejüket. Igen, ez lehet valós veszély, ugyanakkor azt is számba kell venni, milyen eredményeket hoz(hat) a közösség tudománya a „magas” tudományok művelőinek. A számítógép és általában a digitális technológia használata is a gondolkodás egyszerűsödéséhez, végsősoron az újító erő elveszítéséhez is vezethet. Mégis, mindig számolunk az IT kutatást segítő erejével - ma még ezt érezzük erősebbnek, és nem a romboló hatásukat. Az arányokra, vagyis az arany középútra kell mindenkor figyelni, ahogy már az ókorban is felemelkedtek a figyelmeztető ujjak: via media aurea!

4 Citizen Science, Innovation in Open Science, Society and Policy, ed. Hecker, Susanne, Haklay, Muki, Bowser, Anne, Makuch, Zen, Vogel, Johannes, Bonn, Aletta, London, UCL Press, 2018, 580. http://www.oapen.org/ search?identifier=1001816 (utolsó megtekintés: 2021. 07. 03.)

5 Uo., 3. https://discovery.ucl.ac.uk/id/eprint/10058422/1/Citizen-Science.pdf (utolsó megtekintés: 2021. 07. 03.

6 Az Európai Bizottság oldala https://ec.europa.eu/digital-single-market/en/ citizen-science (utolsó megtekintés: 2021. 01. 16.) 
Európában 2014-ben alakult meg a European Citizen Science Association ${ }^{7}$, mely tömöríti a közösségi tudománnyal foglalkozó különböző szakembereket és intézményeket. Célja, hogy támogassa a közösségi tudománnyal kapcsolatos tapasztalatok és ötletek megosztását, terjessze a közösségi tudományos projektek eredményeit, közösséget építsen. Aggregátorként működik, összegyűjti az európai jó gyakorlatokat, a közösségi tudománnyal kapcsolatos irányelveket, útmutatókat, kiadványokat.

Az Egyesület kidolgozta a közösségi tudomány 10 alapelvét $^{8}$, mely nagyban hozzájárul a projektek megvalósításához, kutatócsoportok és jogalkotók megszólításához, az eredmények tudományos elismertségéhez.

1. KözÖSSÉGI TUDOMÁNYOS PROJEKTEK A TÁRSADALOM TAGJAIT AKTÍVAN VONJÁK BE A TUDOMÁNYOS MUNKÁBA, MELYEKBŐL ÚJ TUDÁS VAGY ÚJ ÉRTELMEZÉS SZÜLETIK.

Két nagyon fontos kritériumot tartalmaz az első pont, tulajdonképpen ez adja a közösségi tudományos projektek lényegét. A társadalom tagjai elkötelezett, lelkes önkéntesként, jelentkezhetnek egy közösségi tudományos programban való részvételre, munkájukkal hozzáadott értéket teremtenek, aktívan vesznek részt a folyamatban, melynek tudományos eredménye lesz. A projektek nagy részében az önkéntesek feladata a megfigyelés és az adatok pontos rögzítése, dokumentálása. Az önkéntesek által bevitt adattömeget és információáradatot az adott szakemberek elemzik, értelmezik, így tudnak akár új eredményeket is felmutatni. Egy példával szeretném megvilágítani az adatgyüjtés és dokumentálás lényegét, ami a kutatási folyamat alapját adja. Vegyük például a madárgyưrüzéseket. A madarak befogását, a régi gyűrű

7 A European Citizen Science Association honlapja https://ecsa.citizen-science. net/ (utolsó megtekintés: 2021. 07. 03.)

8 A European Citizen Science Association honlapján a 10 pont https://ecsa. citizen-science.net/wp-content/uploads/2021/05/ECSA_Ten_Principles_ of_CS_English.pdf (utolsó megtekintés: 2021. 01. 16.) 
levételét, az új gyưrű felhelyezését, a gyưrűn lévő adatok adatbázisban való rögzítését nyugodtan rábízhatjuk azokra az elszánt önkéntes fiatalokra vagy felnőttekre, akiket érdekel az ornitológia és szívesen foglalkoznak szabadidejükben a madarakkal. Az ornitológusok pedig a világméretű adatbázisban lévő adatokból dolgoznak. Megállapítják például, hogy egyik helyről a másikra mennyi idő alatt jutott el a befogott madár, az éghajlatváltozás milyen életmódváltozást okoz a madaraknál, vagy hogyan változtatják a vonulási útvonalukat, hogy csak pár szempontot soroljak fel. A példa is rögtön figyelmeztet: csak bizonyos fejlettségű társadalmakban működik ez. A polgároknak rá kell érniük erre a munkára, valóban kell lenni szabadidejüknek. Ők maguk döntsenek arról, hogy ezt a szabad időt erre fordítják. Atársadalmi felelősségtudatnak is jelen kell lennie, amelynek keretében a tudományos megfigyelés fontosságával tisztában vannak. Vagyis látniuk kell, milyen veszélyekkel jár, ha ők komolytalanul nem valós adatokat rögzítenek. A tudóst legfőképpen a saját munkájának fontosságába vetett hit vezényeli - a Föld forgása áll meg, ha egy madár költözési irányait nem ismerik, egy ma már nem beszélt nyelv morfémáit nem fejtik meg, vagy nem tudjuk, mit olvastak a 8. századi Skótföldön stb. -, az önkéntes polgárnak is kell rendelkeznie egy ilyen megszállottsággal. Erre a szintre azonban a társadalomnak el kell jutnia. Ahol a napi étel vagy víz szükségletének biztosítása a gond, ott nem valószínű, hogy felelősséggel fognak mondjuk zsiráf-nyilvántartást vezetni.

\section{A KÖZÖSSÉGi TUDOMÁNYOS PROJEKTEK EREDMÉNYE HITELES TUDOMÁNYOS EREDMÉNY.}

Sokan és sokszor megkérdőjelezik a közösségi tudományos projektek eredményeit, éppen ezért számos tanulmány ${ }^{9}{ }^{10}$ látott napvilágot arról,

9 Bonter, David N., Cooper, Caren B., Data validation in citizen science: a case study from Project FeederWatch, Frontiers in Ecology and the Environment, Vol. 10, issue 6. https://doi.org/10.1890/110273 (utolsó megtekintés: 2021. 07. 03.)

10 Wiggins, Andrea, Newman, Greg, Stevenson, Robert D., Crowston, Kevin, Mechanisms for Data Quality and Validation in Citizen Science, 2011 IEEE Seventh International Conference on e-Science Workshops, Stockholm, 2011, 14-19. https://doi.org/10.1109/eScienceW.2011.27 (utolsó megtekintés: 2021. 07. 03.) 
hogy milyen hitelesítési folyamaton esnek át a különböző képzettségű és tapasztalatú önkéntesek által rögzített adatok. Általánosságban elmondható, hogy nagy különbségekkel találkozhatunk projektenként. A közösség önkéntesei által szolgáltatott adatok minősége elsősorban a projekt előkészítésétől függ. Egy jól előkészített projektben a kutatók vagy a kutatók által felkészített moderátorok (ilyenek lehetnek például a könyvtárosok) érzékenyítik és betanítják az önkénteseket a pontos feladatra, hogy minél egyértelműbb legyen az elvárt minőség. Több esetben előfordul, hogy az önkénteseknek egy alkalmassági vizsgálaton kell átesni, bizonyos kompetenciákra, készségekre van szükség egy-egy feladathoz. Például növények, bogarak leírásánál a színtévesztés kizáró ok lehet, vagy szövegátírásnál az adott nyelv nem ismerete szintén alkalmatlanná teszi az illetőt. Minden közösségi projektben valamilyen szinten ellenőrzésre kerülnek a bevitt adatok, akár szúrópróba-szerűen, akár részletesen, ezeket minden esetben szakemberre bízzák, tehát az ellenőrzés beépített, a kérdés az arányokon van.

Általánosságban elmondható, hogy a jól előkészített projektek estében nagyon magas minőségen, elhanyagolható hibaaránnyal dolgoznak az érdeklődő - hála Istennek, sokszor megszállott - önkéntesek. Később részletesen kitérek a könyvtárak és könyvtárosok szerepére, de itt is aláhúznám, hogy a felkészítő tréningek, amiket sok esetben a könyvtárosok tartanak, a kulcsa a sikeres közösségi tudományos projekteknek.

\section{Mind a tudósoknak, Mind az ÖNKÉNTESEN RÉSZTVEVŐ ÁLLAMPOLGÁROKNAK KÖLCSÖNÖSEN ELŐNYÖS A KÖZÖSSÉGI TUDOMÁNYOS PROJEKTEKBEN VALÓ RÉSZVÉTEL.}

Az önkéntes munkával és az iskolai közösségi szolgálattal rendszeresen találkozunk, ezek alapján elmondhatjuk, hogy még a kelet-európai régiókban is kezd újra elterjedni ez a fajta közösségi vállalás, annak ellenére, hogy a szocialista időkben meghirdetett „társadalmi munka” nem hagyott túl sok pozitív hagyományt maga mögött. Az önkéntesek, akik sok esetben már nyugdíjasok, tehát a szabadidejükkel könnyebben 
gazdálkodnak, örömmel vállalnak feladatokat. Az MTA Könyvtár és Információs Központban jelenleg nyolc önkéntessel van szerződésünk. Őket kérdezve, elsősorban azért vállalnak sokszor nem intellektuális kihívást jelentő feladatot, mert szeretik hasznosnak érezni magukat, a szabadidejüket szeretnék olyan munkával eltölteni, aminek értelme van, szeretnének egy közösség részévé válni, és nem utolsósorban érdekli őket egy könyvtár tevékenysége. A közösségi tudományos projektek sikere az önkéntesek motivációján és eltökéltségén áll vagy bukik, éppen ezért érdemes erre figyelni, és a projektvezetőknek energiát fektetni ebbe. Az angliai Institution of Environmental Sciences ${ }^{11}$ leírása alapján a következő motivációk alapján vállalnak az önkéntesek feladatot: érdekli őket a téma, szeretnének valami újat tanulni, szeretnének valami újat felfedezni, szeretnének több időt tölteni a természetben, olyan emberekkel barátkozni, akiknek hasonló az érdeklődési körük, szeretnének önkénteskedni, szeretnének valamivel hozzájárulni a tudományhoz, úgy érzik, fontos segíteni. Összefoglalva, azok, akik önkéntesként bármilyen feladatot vállalnak, akár közösségi tudományos projektekben, akár jószolgálati tevékenységet, akár egyházi feladatot, úgy érzik, hogy valamit adnak a világnak, ezáltal ők is többek lesznek. (És valóban!)

Talán egyszerűbb volt megfogalmazni, hogy az önkénteseket mi motiválja, de a kutatók, a szakemberek vajon miért választják ezt a megoldást a kutatáshoz?

Elsősorban a nagy tömeg vonzza őket. A közösségi tudományos projektek nagy része természettudományos, országokon, akár kontinenseken átívelő programok (gondoljunk a gólyák vagy a vadludak, fecskék vonulási szokásainak vizsgálatára), képtelenség lenne mindenhova szakembert küldeni, hogy adatokat jegyezzenek fel. Az adott téma iránt érdeklődő és elkötelezett közönség által begyüjtött

11 KRAGH, Gitte, The motivation of volunteers in citizen science, Environmental Scientist, 2016. August, Vol. 25., No 2., 32-35. https://www.the-ies.org/sites/ default/files/journals/es_citizen_science_aug_16.pdf (utolsó megtekintés: 2021. 07. 03.) 
adatokból nagyobb merítést lehet egy-egy kutatás során végezni, a több adat sokkal jobban alátámaszthatja vagy cáfolhatja az elméleteket, tehát a közösség tagjaival tulajdonképpen a humánerőforrás-hiányt pótolják. $\mathrm{Az}$ önkéntes munkáért nem jár semmilyen anyagi honorárium (vagy nagyon ritkán és akkor is minimális összeg), tehát a kutatócsoport nemcsak humánerőforrást nyer, hanem a költségvetés jelentős részét megtakaríthatja és másra fordíthatja. Azért itt meg kell jegyezni, hogy egy jól működő közösségi tudományos projekt költségvetése viszonylag magas, mert a moderátorok és önkéntesek felkészítése költséges, ezen kívül nagyon sokat kell a marketing tevékenységbe fektetni, a motivációt fenntartani az önkéntesekben, ezután jön még csak az adatmentés és archiválás kérdése, ami szintén kiadásokkal jár, és a kutatók megfizetése, hogy legyen tudományos eredménye a projektnek. De visszakanyarodva a kérdésünkhöz, nem véletlen, hogy Európa-, sőt világszerte nagyon sok közösségi tudományos projekt működik. A „miért”-eknél meg kell említenünk egy egyáltalán nem elhanyagolható szempontot is, ez pedig az adott tudományos terület ismertsége. Kutatási projekteket nem szoktak az autópályák mellett óriás plakátokon hirdetni, általában a köz emberének nincs tudomása arról, hogy milyen kérdések foglalkoztatják a tudományos világot. Azáltal, hogy önkéntesek is bekapcsolódnak a munkába, egy új disszeminációs terület nyílik. Már a toborzás során sokan hallanak az adott kutatásról, azok pedig, akik részt vesznek egy-egy tudományos kutatásban, büszkén mesélnek ismerősieknek a „munkájukról”. Ezáltal egy teljesen új, megbízható reklámfelülethez jutnak a kutatócsoportok. A közösségi tudományt legtöbb esetben a természettudományos kutatások használják ki, ezáltal a részt vevő közösséget megfelelően érzékenyítik a klímaváltozásról, a zsiráfok csökkenő egyedszámáról, a madarak megváltozott költözési szokásairól stb. Ennek köszönhetően a közösségi tudományos projektek keretében zajló kutatások sokkal nagyobb ismertségre és elismertségre tesznek szert, így az adott szakmában folyó munkának hírértéke lesz.

A European Citizen Science Association nem vette fel a közösségi tudomány 10 alapelve közé a könyvtárakkal való kapcsolat fontosságát. Úgy vélem, hogy a 2015-ben kidolgozott alapelveket ma már 
mindenképpen ki lehetne egészíteni azzal, hogy Mind a tudósoknak, mind az önkéntesen résztvevő állampolgároknak, mind a könyvtáraknak kölcsönösen előnyös a közösségi tudományos projektekben való részvétel. 4. A KÖZÖSSÉGI TUDOMÁNYOS PROJEKTEKBEN AZ ÖNKÉNTESEK A
TUDOMÁNYOS MUNKA AKÁR TÖBB LÉPÉSÉBEN IS RÉSZT VEHETNEK.

A közösségi tudományos projektek felépítése minden esetben a kutatócsoporttól, a vezető kutatótól függ. Mint minden munkafolyamat, a közösségi tudományos projekt is csak akkor lesz sikeres, ha pontosan előre megtervezik, ha minden feladatnak megvan a gazdája. A szóban forgó projekteknek van olyan része (szervezés, oktatás, marketing, $\mathrm{PR}$, gazdasági, informatikai), mely nem a kutatási terület szakemberének a szakterülete, így akár ezeken a feladatokon is dolgozhat önkéntes. Kifejezetten előnyösnek tartom a marketing és a kommunikációs folyamatokba is bevonni a közösség tagjait, hiszen lelkesedésükkel, elhivatottságukkal újabb és újabb önkénteseket tudnak bevonni a kutatásba. Sokszor tapasztaltam saját munkám során is, hogy a „laikusok” kérdésfeltevései, új perspektívájuk sokszor segítik a munkát, tehát a társadalom tagjai akár kezdeményezői is lehetnek a vizsgálatnak. Ilyen projektek lehetnek például településfejlesztési kérdések vagy a közösségi közlekedés átalakítására, forgalomszabályozásra irányuló kezdeményezések.

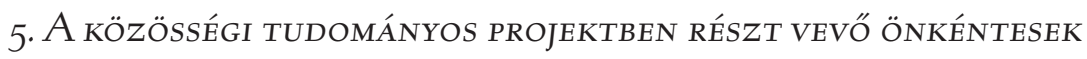
MINDIG KAPNAK VISSZAJELZÉST A PROJEKTRŐL ÉS A MUNKÁJUKRÓL.

Nemcsak a sikeres közösségi tudományos projektek alapja a résztvevőknek szóló visszajelzés, hanem egy jól működő szervezetben is elengedhetetlen az értékelés, minősítés, visszajelzés. Ahogy már beszéltünk róla, fontos a motiváció fenntartása az önkéntesek között, a visszajelzés pedig mindenképpen motivációs eszköz, hogy a résztvevők lássák a munkájuk eredményét, magukénak érezzék a projektet, ne csak a célokkal azonosuljanak, hanem az eredményekkel is. 


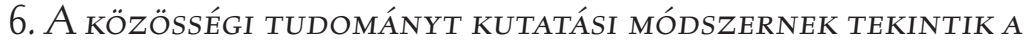
MAGA KORLÁTAIVAL ÉS KUTATÁSI ELFOGULTSÁGAIVAL, MELYEKET A KUTATÁSI FOLYAMAT SORÁN FIGYELEMBE KELL VENNI ÉS ELLENŐRZÉS ALATT KELL TARTANI.

A tudományos módszer alapján a kutatócsoport egy teóriából kiindulva hipotézist állít fel, melyet kvalitatív vagy kvantitatív vizsgálatokkal elemeznek, így a kutatás végén igazolják vagy cáfolják az eredeti állítást. A közösségi tudományos projektek nagy előnye az önkéntesek magas részvétele. Általában egy-egy projekthez nagyon sok önkéntes csatlakozik, ami rengeteg adatbevitelt, megfigyelést és dokumentált azonosítást jelent. Ez a tény magában hordozza a nagy számok elvét, miszerint minél több adatot dolgozunk fel, annál biztosabb megállapításokat tehetünk, így a kutatás elfogultsága is kevésbé jellemző. Sajnos, az is nagyon személyfüggo - és egyre kevéssé jellemző -, hogy a hipotézist nem igazoló adatgyüjtés után magát az elméletet vetik el. Könnyebben minősítik az adatgyűjtést szakmailag hiányosnak, és legyünk őszinték - ha ebben önkénteseket alkalmaztak, egyszerű útnak számít az előfeltevéstől való eltérést ennek számlájára írni.

\section{A közösségi tudományos projeKtek adatai ÉS metaAdatai NYILVÁNOSAK, ÉS AMIKOR CSAK LEHET, AZ EREDMÉNYEKET NYÍLT HOZZÁFÉRÉSSEL KELL PUBLIKÁLNI.}

A közösségi tudomány a nyílt tudomány mozgalom egyik pillére, és mint ilyen, nem kérdés az adatok nyílt hozzáférése és az eredmények, beszámolók, jelentések nyílt publikálása, visszakereshetősége. A nyílt tudomány egyre többet hangoztatott elve a rekonstruálhatóság. $\mathrm{Az}$ államilag támogatott kutatásoknak nemcsak az eredményeihez, publikációihoz kellene hozzáférniük az adófizetőknek, hanem ez azt is jelenti, hogy a nyílt adatok alapján legyen újra rekonstruálható a kutatás, az adatok hozzáférésével egy másik kutató, kutatócsoport is dolgozhasson. Bár nem a Citizen Science témához kapcsolódik közvetlenül, hanem az open data-hoz, de érdemes szemügyre venni a COVID-19, koronavírus-járvány kapcsán látottakat. Nagyon fontos, 
hogy a kutatási adatok nyíltan hozzáférhetőek legyenek a világ minden részén, ez alapján az európai kutatók, így a hazánkban kijelölt szegedi biológusok is hozzáférhettek a kínai orvosok által regisztrált esetekhez. Ugyan, ez egy nagyon szép elv, de, sajnos, soha nem fog teljesen megvalósulni, mert az érdekek és a pénz mindig közbeszól.

\section{A KÖZÖSSÉGi TUdOMÁNYOS PROJEKTEKBEN RÉSZT VEVŐ ÖNKÉNTESEKET KÖSZÖNETNYILVÁNÍTÁS ÉS ELISMERÉS ILLETI MEG A PROJEKT EREDMÉNYEINEK KÖZZÉTÉTELEKOR ÉS A PUBLIKÁCIÓKBAN.}

A közösségi tudományos projektekben soha nem fogják nevén nevezni a több ezer résztvevős önkéntest, de összességében alapvető elvárás, hogy a kutatás alapját biztosító tömeg mégis érezze a tudományos világ elismerését. A kisebb, helyi közösségekben létrejött projekteknél pedig a település is biztos büszke az önkénteseire, így nem is felejtik el név szerint megköszönni a közremúködésüket.

A köszönetnyilvánítás nemcsak az adott projekt szempontjából fontos, hanem a jövőre nézve is, hiszen ez is motivációs eszköz! Aki megbecsültnek, hasznosnak, eredményesnek érezte magát és munkáját egy adott közösségi tudományos projektben, az szívesen csatlakozik egy újabbhoz.
9. A KÖZÖSSÉGI TUDOMÁNYOS PROGRAMOKAT A TUDOMÁNYOS EREDMÉNYÜK ALAPJÁN, AZ ADATOK MINŐSÉGE, A RÉSZTVEVŐK TAPASZTALATAI ÉS A TÁGABB TÁRSADALMI ÉS SZAKMAPOLITIKAI HATÁSUK ALAPJÁN KELL ÉRTÉKELNI.

A European Citizen Science Association által kiadott 10 alapelv 9. pontja azt mondja ki, hogy mi alapján értékeljük a projekteket, de a fenti állításban megbújik egy nagyon fontos, ki nem mondott és le nem írt értékelési lehetőség, mégpedig az, hogy mi alapján ne értékeljük a közösségi tudományos projekteket: ez pedig a résztvevő 
önkéntesek száma. Bár már beszéltünk arról, hogy a nagy számok elve alapján valószínűsíthető, hogy ha minél többen vesznek részt egy megfigyelésben, átírásban, annál pontosabb lesz, de ez nem lehet az egyedüli értékelési alap. Tudunk olyan projektről, amelyben az önkéntesek egy személy kéziratos hagyatékát gépelik le, és így kerül be egy nagy adatbázisba a szöveg. Mivel a 19. század elején írt angol kéziratok olvasása mindenképpen szakértelmet, de legalábbis rutint igényel, ezért a programban hatékonyan résztvevők nem haladják meg az Egyesült Királyság-szerte a tíz főt, mégis, sikeres és tudományos mércével is igen fontos munka alapját teszik le. Gondoljunk bele: az MTA 2021-ben megvette Erdélyi János (1814-1868) és fia, Erdélyi Pál (1864-1936) irathagyatékát. Ez ma a legnagyobb 19. századi irodalmi hagyatékok egyike. Feldolgozása részben megtörtént, a benne őrzött szövegkorpusz átírása, tudományos feldolgozása és kiadása évtizedeket vesz majd igénybe. Egy ilyen tízfős csapat szervezése, felkészítése a munkára fél évet elvinne, de feltehető, hogy fél évtizedet megspórolnának a kívánt eredmény eléréséig. Közben lenne egy pozitív társadalmi hatása is a folyamatnak. Azonban sem a magyar irodalomtudományi élet, sem a társadalom nem érett még egy ilyen megoldásra.

\section{A KözösSÉgi tudományos projeKtek VezetőI figyelembe} VESZIK A SZERZŐI JOG JOGI ÉS ETIKAI KÉRDÉSEIT, MINT A SZELLEMI TULAJDON, AZ ADATMEGOSZTÁSI EGYEZMÉNYEK, A BIZALMI VAGYONKEZELÉS ÉS TEVÉKENYSÉGÜK KÖRNYEZETI HATÁSAIT.

Természetesen a nyílt hozzáférés nem jelenti azt, hogy ne kellene Európa-szerte figyelembe venni az Általános Adatvédelmi Irányelvet (GDPR), a szerzői jogot vagy bármely más hatályos rendelkezést, ami egy-egy kutatásnál felmerülhet. A teljes anonimitás biztosítása ugyanakkor a felelőtlenséget is nagyobb eséllyel engedné meg. Ha valaki közmunkát végez, ezt vállalja, ahogy vállalják is a résztvevők, azt ne anonim módon tegye. 


\section{KÖZÖSSÉGI TUDOMÁNYOS PROJEKTEK}

Az angolszász szakirodalom az 1900. évben kezdődött Karácsonyi Madárszámlálást (Christmas Bird Count ${ }^{12}$ ) tartja a legrégebbi dokumentált közösségi tudományos projektnek - persze, akkor még nem így hívták. 1900 karácsony napján (december 25.) hirdette meg egy észak-amerikai ornitológus, Frank M. Chapman a madárszámlálást, mivel meg volt győződve arról, hogy a madárpopuláció kihalóban volt a karácsonyi galamblövészet szokása miatt. A vadászatot szerette volna felváltani a számlálással, és már az első évben sikeres volt a kezdeményezése, 27 madárszámláló csatlakozott hozzá, és 25 különböző területről küldtek adatot, Torontóból, Ontario-ból, Pacific Grove-ból és Kaliforniából.

A Karácsonyi Madárszámlálás jó példa a közösség bevonására, azonban nem is gondolnánk, hogy hazánkban már 1881-ben közösségi tudományos projekt keretében szervezte meg Heller Ágost a zivatarészleléseket. A Természettudományi Közlöny (1881. június) 13. évfolyam 142. számában a Levélszekrény rovatban (p. 277.). ${ }^{13}$ Heller Ágost 13 pontban adta meg a megfigyelési módszereket, melyek nagyon részletes leírást és összehasonlítást tettek lehetővé. Két évvel később szintén a Természettudományi Közlöny ${ }^{14}$ hasábjain ismételte meg a felhívást, és egyben köszönetet mondott az adatküldő önkénteseknek, kiemelve név és foglalkozás, illetve település szerint a legteljesebb leírást küldőket. A zivatarokat, villámcsapásokat dokumentálók között volt tanító, lelkész, főgimnáziumi tanár és gyógyszerész is.

12 History of the Christmas Bird Counting https://www.audubon.org/ conservation/history-christmas-bird-count (utolsó megtekintés: 2021. 07. 04.)

13 Zivatarok statisztikája érdekében, Természettudományi Közlöny, 142(1881), 13. évf., 277. http://real-j.mtak.hu/6576/1/TermtudKozl_1881.pdf\#page=289 (utolsó megtekintés: 2021. 07. 04.)

14 Heller Ágost, Zivatarok statisztikája érdekében, Természettudományi Közlöny 166(1883), 15. évf., 285. http://real-j.mtak.hu/6578/1/TermtudKozl_1883. pdf\#page=293 (utolsó megtekintés: 2021. 07. 04.) 
Manapság az újdonság a nyílt tudományban rejlik, a nyílt adatokban és a nyílt hozzáférésben és persze a technikai háttérben, melynek segítségével az elemzések egyre összetettebbek és sokoldalúbbak lehetnek. A projektekbe rengeteg erőforrást fektetnek a szervezők, hiszen ki kell építeni egy informatikai hátteret, fel kell készíteni a projektben részt vevő önkénteseket, folyamatosan ellenőrizni kell az adatokat, és visszajelzést kell adni az önkénteseknek. A mai online világban tulajdonképpen állandóan talpon kell lenni, és állandóan fenn kell tartani az érdeklődést és a lelkesedést.

Számos jól bevált közösségi tudományos projektet sorolhatnánk fel, a Zooniverse.org kifejezetten azt a több mint egy millió fős nemzetközi önkéntes közösséget fogja össze, akik örömmel vállalnak feladatot egyegy kutatásban. Színes a kínálat, a csillagszámlálástól, a zsiráfok foltjai alapján való azonosítástól, pingvinszámlálásig nagyon sokféle projekt megtalálható.

A jó gyakorlatok között egy olyan angliai példát szeretnék kiemelni, amikor a tudományos könyvtár nemcsak szervezi a projektet, hanem a kutatást is a könyvtár vezeti. Ez a University College London egyetemi könyvtára által kezdeményezett és koordinált Transcribe Bentham ${ }^{15}$ projekt. A projekt több szempontból is érdekes számunkra, hiszen kifejezetten kulturális örökségünk megőrzésére irányul, illetve jó példája a könyvtárban és könyvtári gyűjteményen alapuló projekteknek. Jeremy Bentham (1748-1832) angol filozófus, bíró, az utilitarizmus atyja és egyben a London University (1826) alapítója (az egyetem később, 1836-ban vette fel a University College London nevet), kéziratos hagyatékát az egyetem könyvtárában őrzik. A University College London elkötelezett híve a nyílt tudománynak, az egyetem égisze alatt, szervezetileg pedig a könyvtárban hozták létre az Egyesült Királyság első Open Access (nyílt hozzáférésű) kiadóját is ${ }^{16}$, így aztán nem

15 University College London honlapja, Transcribe Bentham https://blogs.ucl.ac.uk/transcribe-bentham/ (utolsó megtekintés: 2021. 07. 04.)

16 University College London Press honlapja https://www.uclpress.co.uk/ (utolsó megtekintés: 2021. 07. 04.) 
meglepő, hogy elsőként vágott bele az egyetemi könyvtár egy könyvtári gyűjteményen alapuló közösségi tudományos projektbe. A Transcribe Bentham célja a könyvtárban található 60000 fólió Bentham-kéziratok eddig feldolgozatlan 12500 fólió feldolgozása, átírása és kiadása. Az önkéntesek feladata a szkennelt kéziratok átírása megadott szabályok alapján a projekt elektronikus felületén. A projektet 2010-ben hirdették meg, az elmúlt időszakban a 46535 szkennelt képnek a felét sikerült átírni. Időközben az önkéntesek munkája mellett kipróbálásra kerül egy új kézírást felismerő szoftver is, ami még egyáltalán nem helyettesíti az önkéntesek munkáját. A munkafolyamatot pontos tervezés előzte meg. Mi, akik könyvtárban dolgozunk, tisztában vagyunk a hatalmas értékes hagyatékok feldolgozatlanságával, hazánkban a 19. századi kéziratok nagy része kiadatlan maradt, és, sajnos, feldolgozatlan is. A technikai fejlesztéseknek köszönhetően sok munkafolyamatot lehet már mesterséges intelligenciával helyettesíteni, de számos területen még mindig nem tudjuk kikerülni az emberi agy produktivitását. A meghirdetett közösségi tudományos projekthez való csatlakozás regisztrációval és felkészülési idővel kezdődik. A regisztráció során az általános adatokon kívül a rövid kérdőív kitér arra is, hogy az átíró önkéntesnek van-e bármilyen paleográfiai tapasztalata vagy képzettsége. Az önkéntesek által készített gépiratokat minden esetben a könyvtár és egyetem szakemberei ellenőrzik. Az egyik leggyakrabban felvetődő kérdés, hogy milyen hatékonysággal dolgoznak az önkéntesek, nem több idő-e és energia a gépiratok ellenőrzése, összevetése az eredeti szöveggel. Minden kétséget eloszlató elemzés jelent meg 2018-ban ${ }^{17}$, mely a projekt időszakából nagyjából két évet alapul véve 2012. október 1. és 2014. június 27. közötti időszakot vizsgálva kimutatta, hogy az ellenőrzések során csupán a bevitt szavak 1\%-át kellett az ellenőrző szakembereknek módosítani. A projektre fordított energia megtérülése szokott még kérdés lenni. Pénzbe, időbe kerül létrehozni azt az

17 Causer, Tim, Grint, Kris, Sichani, Anna-Maria, Terras, Melissa, 'Making such bargain': Transcribe Bentham and the quality and cost-effectiveness of crowdsourced transcription, Digital Scholarship in the Humanities, Vol. 33, Issue 3, September 2018, 467-487. https://doi.org/10.1093/llc/fqx064 (utolsó megtekintés: 2021. 07. 04.) 
informatikai hátteret, mely alapot biztosít a szkennelt dokumentumok láthatóvá tételére és a gépiratok mentésére. Szükség van egy nagy kapacitású szerverre is, ahol a repozitóriumi anyagot archiválni lehet. Az önkéntesek felkészítése, a velük való kapcsolattartás, kérdéseikre való válaszadás szintén megkövetel egy háttérmunkát. A csapat részét képezik azok a szakemberek, akik az átírásokat ellenőrzik, és azok is, akik a kész részeket előkészítik kiadásra, szerkesztik a már begépelt részeket. Az informatika ma már számos más kutatási területet is segít, így nemcsak szövegbányászati eszközökkel elemzik a gépiratokat, a benne szereplő neveket, hanem a legújabb kézírás-felismerő szoftver használatával megállapítják, hogy „hányféle kéz” segítette Bentham munkáját.

Ahogy írtam is, a projekt 2010-ben kezdődött, de még mindig tart, és valószínűsíthető, hogy még jó pár évig van munkájuk azoknak az önkénteseknek, akik örömüket lelik Bentham kéziratainak feldolgozásában. A projektről beszámoló cikkek egyértelmű sikerként mutatják be a projektet annak ellenére, hogy igen elhúzódó, a projektvezetés már többször cserélődött ez idő alatt. Látni kell, hogy a siker és a részeredmények, illetve majd a végső kiadás nagyban függ az intézmény elköteleződésétől, a projekt szervezésétől, az önkéntesek korrekt tájékoztatásától, a folyamatos motivációtól. A közösségi tudományos projektek között nem szokványos az ilyen hosszú feladat, talán ez az egyetlen, amit nem biztos, hogy jó gyakorlatként át kellene venni a University College Londontól, azonban nagyon tanulságos a magyar könyvtárak, muzeális gyűjtemények számára. Nem kell messzire menni egy közgyüjteménynek sem a feldolgozatlan, akár ismeretlen anyagok tekintetében, sokszor egy-egy hagyatékról azon kívül, hogy van, nem tudunk semmit. Kulturális örökségünk részei. A közösségi tudományos projektek újabb lendületet adhatnak lappangó javaink felkutatásában és bemutatásában. Még becsülni is nehéz lenne, hogy pontosan hány kézirat-, fényképgyüjtemény van közgyüjteményeinkben. 


\section{A KÖZÖSSÉGI TUDOMÁNY SZEREPLŐI}

A кutatók

A közösségi tudomány definiálásával egyértelművé tettük, hogy legalább két „szereplője” van a projekteknek: a kutató, tudós, szakember és az érdeklődő önkéntes. A találkozás azonban nem mindig egyszerű, a felek egymásra találásában több szereplő is részt vehet. A Zooniverse internetes felület megalkotásával éppen a kommunikációt és az egymásra találást kívánják segíteni. A Zooniverse weboldalt a Citizen Science Alliance (Közösségi Tudomány Szövetség) gondozza, főként tudományos munkával foglalkozó szakemberek, szoftverfejlesztők és oktatók a világ különböző egyetemeiről vesznek részt a munkában. Két központja is van a Szövetségnek, az Oxfordi Egyetem NagyBritanniában és az Adler Planetárium az Amerikai Egyesült Államokban. A Zooniverse nemzetközi platform, mindenképpen érdekes számba venni a felsorolt projekteket; jól látható, hogy egy nemzetközi internetes portál mennyire megmozgatja az embereket, aktivizálja az érdeklődőket. Véleményem szerint, azonban hazánkban mégsem fog elterjedni a Zonniverse használata, már csak a nyelvi akadályok miatt sem, a projektek angol nyelvtudást igényelnek. A másik fó akadályt abban látom, hogy nincs személyes kapcsolat az önkéntesek és a szakemberek között, de még az önkéntesek és az aggregátor, moderátor szerepét betöltő platform között sem. Éppen ezért gondolom úgy, hogy a közgyüjtemények, így a könyvtárak, tökéletesen be tudják tölteni a harmadik fél szerepét. A könyvtárak rengeteg hozzáadott értéket tudnak egy-egy projektbe vinni, melyre később bővebben is szeretnék kitérni.

A közösségi tudományos projektek szereplőinél inkább azt vizsgáljuk meg, melyik félnek miért éri meg részt venni, milyen „haszonnal” jár egy-egy tudományos projekt.

A Nyugat-Európában, az Egyesült Államokban gyorsan terjedő kutatási módszertantól hazánkban a természettudósok már egyre kevésbé tartanak, a bölcsészek azonban szkeptikusak az eredményeket illetően. 
A már megvalósult projektekből jól látszik, hogy a sok önkéntest megszólító programok olyan lehetőségeket nyújtanak a szakemberek számára, amelyek máskülönben, humánerőforrás hiányában soha nem valósulhatnának meg. Például a Magyarország növényzetét vagy állatvilágát feltérképező (MÉTA ${ }^{18}$, Vadonleső ${ }^{19}$ ) programok lehetővé teszik az önkéntesek online adatszolgáltatását, adott fajok helyzetmegjelölését. Az így összegyüjtött, országos lefedettséget biztosító adatokból a kutatók folyamatosan tudják frissíteni az aktuális élőhely-adatbázist és élőhelytérképet. A szakmai eredmények mellett célkitűzés a közösségek felkarolása, a különböző társadalmi csoportok összefogásának ösztönzése, az adott szakterületre vonatkozó (pl. ökológia, botanikai, csillagászati, történelmi stb.) ismeretek fejlesztése és a szemlélet formálása. A szakemberek a közösségi tudományos projektek kapcsán hiteles, gyorsan terjedő disszeminációs csatornához is hozzájutnak. Nem lebecsülendő, hogy a fiatalabb korosztály megszólításán keresztül, akár az utánpótlás biztosítására is van lehetőség. Tulajdonképpen az önkéntesek „ingyen” munkaerőt jelentenek a szakembereknek, azonban ez a megfogalmazás a folyamatok teljes leegyszerűsítése, hiszen a szakemberek minden esetben nagyon sok munkaórát tesznek bele az önkéntesek felkészítésébe, tájékoztatásába és a munkát követő „szabadidős” programokba.

\section{Az ÖNKÉNTESEK}

A European Citizen Science Association által összeállított alapvetéseknél már volt szó arról, hogy miért előnyös egy programhoz való csatlakozás az önkénteseknek. Fontosnak tartom hangsúlyozni, hogy a közösséghez való tartozás a 21 . század emberének fontos lételeme, az a tudat, hogy tevékenységünkkel, önkéntes munkánkkal hasznos dolgot, maradandót hozunk létre, szintén nem elhanyagolható. Ezen kívül pedig a résztvevők még élvezik is a feladatokat, ami saját önbecsülésüket is támogatja.

18 MÉTA program, Magyarország növényzeti öröksége https://www.novenyzetiterkep.hu/ (utolsó megtekintés: 2021. 07. 04.)

19 Vadonleső: önkéntesekkel a természetért https://vadonleso.hu/ (utolsó megtekintés: 2021. 07. 04.) 


\section{A KÖNYVTÁRAK}

A közösségi tudományos projekteknek nem alapvető, de hasznos résztvevője a könyvtár. Sok közösségi tudományos projekt elérhető a világhálón működő aggregátor felületeken, amelyek több ezer projektet kínálnak az önkénteskedő embereknek. A Zooniverse ${ }^{20}$ honlap leírása szerint egymillió ember kapcsolódik be a felkínált világméretű projektekbe. A több országon átívelő, akár különböző kontinenseket érintő projektek nagyobb költségvetéssel és nagyobb merítéssel dolgoznak. Azonban nagyon sok helyi, egy-egy kisebb közösséget, települést, egyetemi campuson élőket megmozgató közösségi tudományos projekt létezik világszerte, ahol a közösségi tudományos projekt résztvevői, azaz a kutató, az adott terület szakembere és az önkéntesen csatlakozó érdeklődő mellett megjelenik a könyvtár is, sok esetben a könyvtárak a projekt csomópontjai (hub), mozgatói. A könyvtár moderátorként kapcsolatot jelent a kutatócsoport, a tudományos világ és a projektben résztvevő emberek között. A könyvtárak általában egy-egy település, közösség középpontjában helyezkednek el, a látogatóközönségük nagyon széles skálán mozog, a gyerekektől a szülőkön keresztül a nyugdíjas korú emberekig, az egyetemeken pedig egyszerre használják az egyetemisták és az oktatók, kutatók, tehát az adott közösség minden tagja megfordul a könyvtárban. Ezen kívül a könyvtárhasználókról általánosságban elmondható, hogy érdeklődőek, nyitottak az újra, különböző szakterületüknek és különböző koruknak köszönhetően különböző módon látják a feladatot. A könyvtár, és leginkább a szakkönyvtárak, egyetemi könyvtárak, informatikai infrastruktúrája magas szinten áll, még Magyarországon is a legtöbb egyetemi és szakkönyvtár repozitóriumot működtet, már egyre több intézmény készen áll adatrepozitórium működtetésére is. Amiben a könyvtárak a legjobbak (sajnos, sok esetben a legnagyobb gyengesége is ez sok könyvtárnak): a jól képzett humánerőforrás, tehát maga a könyvtáros. És ha már az infrastruktúrát említettük, nem szabad megfeledkeznünk magáról a helyről. A könyvtárakat ma már csomópontként, találkozóhelyként (hub) emlegetjük, a harmadik hely, szocializációs színtér. A közösségi tudományos projektek

20 Zooniverse https://www.zooniverse.org/ (utolsó megtekintés: 2021. 02. 23.) 
szempontjából egy „semleges” terület, ahol otthonosan mozoghat az átlagember is és a kutató is. Hiteles hely, bár sokat emlegetjük ezt a kifejezést, de talán mégsem eleget. Igen, a könyvtárak megbízhatóak, a könyvtárban található információk és információforrások megbízhatóak, és a könyvtárosok szintén megbízhatóak. A könyvtárban dedikált helyet lehet biztosítani a közösségi tudományos projektekkel kapcsolatos tájékoztató anyagoknak, szórólapoknak (ahogy sok más terület számára is). Még akkor is állíthat össze a könyvtár egy tájékoztató leporellót, ha más módon nem is vesz részt a közösségi tudományban. Felhívhatja a figyelmet az aggregátor honlapokra, helyi közösségi tudományos projektekre, egy-egy projektben való részvétel jelentőségére, tapasztalatszerzésre. A könyvtáraknak (minden típusnak) alapfeladata az információáramlás támogatása, így jól megférnek egymás mellett az EU prospektusok, a katalógushasználati tájékoztatók vagy a könyvtár soron következő kulturális programját bemutató plakátok. Azonban az alapvető információk mellett a könyvtárnak szerepe van abban is, hogy a helyi, adott közösségben zajló közösségi tudományos projekteket támogassa. Ebben az esetben a „közösségi ponton” már konkrét információval tudják ellátni az érdeklődőket. A megvalósult európai közösségi tudományos projektek azt mutatják, hogy a könyvtárosnak kulcsszerep jut egy-egy projektben. Mindenképpen építhetünk a könyvtárosok kommunikációs készségeire és gyakorlatukra - megfelelő felkészítés után (képzők képzése) - a könyvtárosok lesznek azok, akik felkészítik, betanítják az önkénteseket és tájékoztatják a résztvevőket a közösségi tudományos projektek menetéről, lehetőségeiről, a csatlakozás tudnivalóiról, és ugyancsak a könyvtárosok azok, akik kapcsolatot tartanak a tudományos projekt vezetőjével is, így valóban a híd szerepét töltik be.

Az európai tapasztalatok azt mutatják, hogy a legtöbb közösségi tudományos projekt egy-egy egyetemről indul, így az egyetemi könyvtárak kézenfekvő segítséget jelentenek a projekt sikeres lebonyolításához. Ma már hazánkban sem elkülönülten dolgoznak a könyvtárosok, hanem az egyetemi tanszékekkel együttműködve, 
úgynevezett szakreferensekkel. ${ }^{21}$ A szakreferensi szolgálat kifejezetten jó hatással van a könyvtárhasználati statisztikákra is, hiszen a kölcsönös bizalom következtében sokkal többen fordulnak a könyvtárhoz és a könyvtároshoz. A könyvtárosok elfogadottsága, ha úgy tetszik, a hierarchia mind a két végéről biztosított, oktatók, kutatók is és a hallgatók is szívesen és könnyen fordulnak a könyvtárosokhoz. Ez az a bizalmi viszony, amelyre a közösségi tudományos projektek építenek a könyvtárak bevonásával.

A közösségi tudományos projektek zöme természettudományos jellegü, megfigyeléseken és adatrögzítésen alapulnak. Az adatok pontos rögzítése és biztonságos tárolása minden projektnél elengedhetetlen. A könyvtárak minősített adatrepozitóriumai megfelelnek a kutatási módszertan elvárásainak, a könyvtárakban dolgozó adatkurátorok (data curators) pedig szakszerűen kezelik az adatokat.

Eddig csak azokról a közösségi tudományos projektekről beszéltünk, amelyekben a könyvtár moderátorként, összekötőként áll az önkéntesek és a kutatócsoport között.

Mindenképpen fontos azonban megemlíteni, hogy a könyvtár gyüjteménye egy-egy kutatás alapja, helyszíne is lehet. Írott kulturális örökségünk zömmel könyvtárakban lelhető fel, olyan értékek rejtőznek sokszor intézményeinkben, amiről csak sejtésünk van. Az egyik legszemléletesebb példát már említettük a közösségi tudományos projekteknél, a University College London Citizen Science projektje a Transcribe Bentham ${ }^{22}$, mely az egyetemi könyvtár gyüjteményében található Jeremy Bentham-kéziratok átírását tűzte ki célul. A Benthamprojekt egy európai konzorcium részeként elnyerte az Európai Bizottság

21 Meskó Eszter, Egy könyvtár - tizenkét kar: az SZTE Egyetemi Könyutár szakreferensi rendszere, TMT, 57. évf., 4(2010). http://tmt-archive.omikk.bme.hu/show_news. html@id=5308\&issue_id=514.html (utolsó megtekintés: 2021. 07. 04.)

22 Project Update - Transcribe Bentham, woman and citizen science (23 March 2018) https://blogs.ucl.ac.uk/transcribe-bentham/2018/03/23/project-updatewomen-and-citizen-science/ (utolsó megtekintés: 2021. 07. 04.) 
Horizon Impact Award 202023 díját is, lappangó kulturális örökségünk hozzáférése kapcsán tett erőfeszítéseiért.

A londoni példa jól mutatja, hogy a kulturális örökségünket őrző gyűjteményeknek nem szabad megijedniük a lehetőségtől. A siker titka egyértelműen a jól megtervezett és felépített projekt, mely illeszkedik az intézmény hosszútávú stratégiájába. Úgy gondolom, fontos megjegyezni, hogy a közösségi tudományos projektek nem ingyenesek, nem nulla forintos költségvetésből megvalósítandók. Rengeteg energiabefektetéssel jár, mind a kutatócsoportnak, mind az üzemeltetési feladatokat ellátó kollégáknak.

A könyvtár - ha nem is hiteleshely (locus credibilis, mert akkor gazdag lehetne) - hiteles hely ${ }^{24}$. Egyre többet beszélünk a könyvtárról, mint harmadik helyről, a könyvtár közösségben betöltött szerepéről, de nem szabad megfeledkeznünk arról a tényről, hogy a könyvtár az a hely, ahol az információáradatban elvesző állampolgár segítségre találhat. A European Citizen Science Association által megfogalmazott alapelveknél is utaltam már a könyvtárak szerepére. A könyvtár tájékoztató tevékenysége nagyban hozzájárulhat egy-egy helyi közösségi tudományos projekt sikeréhez, elsődlegesen hiteles információkkal.

A könyvtárakban, világszerte, különböző tájékoztató pontokat állítanak fel, például az EU információs pontok. A közösség tagjai tudják, hogy az itt elérhető információk megbízhatóak. Éppen ezért többfajta kiadványt, szórólapot kell elhelyezni a „Közösségi tudományos ponton”, elsősorban arról, hogy mi a közösségi tudomány, hogyan zajlik egyegy projekt, hogyan lehet csatlakozni, milyen eredmények várhatóak, miért éri meg bárkinek is önkéntes munkát vállalni egy programban, és ha a településen vagy az adott közösségben (egyetemen) már elérhető

23 Consortium including Bentham Project receives European Commission's Horizon Impact Award for 2020 https://www.ucl.ac.uk/laws/news/2020/ sep/consortium-including-bentham-project-receives-european-commissionshorizon-impact (utolsó megtekintés:2021. 07. 04.)

24 Kokas Károly, Nagy Gyula, Molnár Sándor, A könyvtárak jövőjérōl - Reflexiók egy elózetes kutatási jelentés kapcsán, TMT, 2(2017), 64-82. 
közösségi tudományos projekt, akkor erről mindenképpen érdemes tájékoztatni az érdeklődőket. Ezek a kiadványok a figyelemfelkeltés és az érzékenyítés első fázisai. ${ }^{25}$

A könyvtár híd a kutatócsoport és az önkéntesek között, és a hídfőkön ott állnak a könyvtárosok. A szórólapokat kézbe vevők, érdeklődők kérdezni fogják a könyvtárost, neki pedig felkészülten kell válaszolnia. Tehát a könyvtárosok felkészítése és megfelelő minőségű és mennyiségű információval való ellátása a kutatócsoport munkáját segíti. Az általános információnyújtáson túl a helyi projektekhez kapcsolódóan az önkéntesek felkészítését, csoportos tájékoztatását is a könyvtárosokra lehet bízni. A könyvtárosok kommunikációs készségei és képességei már kipróbáltak, a felhasználóképzések terén már bizonyítottak, csoportos foglalkozások megszervezésében és megtartásában is számos eredményt tudnak felmutatni, nem is beszélve a napi kapcsolattartással járó helyzetekről. A könyvtáros egyben kapcsolattartó a projektért felelős kutatócsoport és az önkéntesek között, a kutatócsoport munkáját nagyban megkönnyíti, ha a könyvtárra és a könyvtárosokra támaszkodhat, hiszen nem kell kiépítenie a projekthez tartozó kommunikációs csatornát, felhasználhatja egy jól működő szervezet előnyeit.

A könyvtári szervezet másik előnye az infrastruktúra. A hely, a „harmadik hely”, a közösség számára az otthon és a munkahely mellett a kikapcsolódás helye is, csomópont, találkozási pont (hub). Az újonnan épülő könyvtáraknál megfigyelhető az az alapvető igény, hogy a társadalom, a közösség minden tagjának biztosítsák a megfelelő helyet, így vannak az elmélyült munkára, olvasásra, tanulásra kialakított részlegek, a csoportos foglalkozásokhoz használható előadók és a kiscsoportos közös munkához használható helyiségek, ezen kívül pedig a közösségi terek. A program során a könyvtár adhat otthont a kutatásban résztvevő helyi önkénteseknek a tájékoztatók, felkészítő programok megtartására, de a könyvtár lehet a színtere az eredményeket bemutató sajtótájékoztatónak vagy kiállításnak is. Kihasználva a könyvtárak és

25 Lásd melléklet Közösségi tudomány „szórólap”. 
könyvtárosok előnyeit, képességeit, érdemes a könyvtárosokra bízni az önkéntesek felkészítését. A projektben résztvevő szakemberekről nagy terhet vehetnek le a könyvtárosok, és persze rengeteg időt takaríthatnak meg azzal, ha a szakemberek a könyvtárosokat készítik fel, amolyan képzők képzése tréninggel, hogy később a könyvtárosok tartsák meg időről időre a projekthez csatlakozó önkéntesek felkészítését. A tudományos projekt témájától és területétől függően más és más elvárás van az önkéntesek felé, a pontos munkavégzés menetét, mint például a méréseket, adatbevitelt, szoftverhasználatot a könyvtárosok taníthatják meg az önkénteseknek.

A könyvtár információtechnológiai infrastruktúráját is számos területen tudja hasznosítani a helyi közösségi tudományos projekt. Az európai egyetemi könyvtárak tapasztalatai szerint az egyetemi könyvtár által fenntartott és működtetett repozitóriumok és adatrepozitóriumok nem csak archiválásra használhatók, hanem biztosítják az adatokhoz való nyílt hozzáférést is. Ehhez kapcsolódnak azok a szakmai kompetenciák, amelyekkel a könyvtárosok nemcsak gyüjtik, hanem karban is tartják a repozitóriumi dokumentumokat, hogy megtalálható, visszakereshető és újra hasznosítható legyen.

Egy közösségi tudományos projekt számára a könyvtár még egy hatalmas potenciális erővel bír, ez pedig a megszólítható önkéntesek nagy száma.

Feltehetjük a kérdést, de vajon miért éri meg a könyvtáraknak láthatóan sok energiát fektetni egy közösségi tudományos projektbe?

A különböző könyvtártípusok (közkönyvtár, egyetemi vagy szakkönyvtár) alapfeladata az információhoz való hozzáférés biztosítása. Ezen túl a közkönyvtárak szerepe az adott településen a magyar könyvtári rendszerben szerencsére igen számottevő, a kistelepülések feladatellátásához külön költségvetést rendel az állam (39/2013. (V. 31.) EMMI rendelet a Könyvtárellátási Szolgáltató Rendszer múködéséről), de a helyi értékek felkutatásában, megőrzésében és közzétételében a Hungarikum törvény (2012. XXX. törvény a magyar nemzeti értékekről 
és a hungarikumokról) is a településeket támogatja a helyi értéktárak létrehozásában. Az egyetemi szakkönyvtárak további alapfeladata a kutatás támogatása. A kutatástámogatás formája, eszköze változik, ehhez pedig a könyvtárak alkalmazkodnak. Meglévő szolgáltatásinkat nem sokkal kell kiegészíteni ahhoz, hogy sikeres közösségi tudományos projektekben vegyünk részt. A közösségi tudomány (Cítizen Science) a nyílt tudomány (Open Science) egyik pillére. A hazai egyetemi könyvtárak és szakkönyvtárak rengeteget tesznek azért, hogy a magyar tudományos kibocsátás láthatóbb és elérhetőbb legyen a világ minden részéről, számos jó gyakorlat hozzáférhető. A közösségi tudományos projektekkel éppen azt a célt tudjuk szolgálni, ami a nyílt tudomány célja, hogy a más szakterületen dolgozó laikusoknak is átláthatóbb, érthetőbb és kézzel foghatóbb legyen egy-egy kutatási téma. A közösség bevonásával ezt a célt tudjuk erősíteni. Ezen kívül pedig egy közösségi tudományos projekt felér egy remek marketing eszközzel, hiszen újabb fórumot biztosítunk a szolgáltatásaink népszerűsítésének, alkalmunk nyílik mind a kutatói társadalom, mind az érdeklődő laikusok számára megmutatni, hogy hatalmas lehetőségek rejtőznek falaink között.

A közgyüjtemények számára a marketing kulcskérdés. Vannak ezen a területen sikeresebb és kevésbé sikeres intézmények. Egyértelmü segítség a központilag indított tudománynépszerűsítő tematikus napok, ilyen hazánkban a Múzeumok éjszakája vagy a Kutatók éjszakája, melyek lehetőséget adnak a kisebb költségvetéssel rendelkező intézményeknek is a megmutatkozásra, kihasználva a központi promóció lehetőségét. Könyvtári területen az Informatikai és Könyvtári Szövetség koordinálása mellett az Országos Könyvtári Napok ${ }^{26}$ nyújt hasonló megjelenési lehetőséget a hazai könyvtáraknak. Az Amerikai Egyesült Államokban működő Citizen Science Association civil szervezet évről évre meghirdeti a Közösségi Tudomány Hónapját ${ }^{27}$, minden év áprilisában. Az Egyesület központi logóval, marketing

26 Informatikai és Könyvtári Szövetség honlapja, Könyvtári napok http://iksz.org. hu/hir/orszagos-konyvtari-napok-2 (utolsó megtekintés: 2021. 07. 04.)

27 Citizen Science Association https://www.citizenscience.org/events/citizenscience-month/ (utolsó megtekintés: 2021. 03. 13.) 
anyagokkal segíti a résztvevő intézményeket, közös felhívásokkal igyekeznek népszerűsíteni a tudományos projekteket, munkákat. A segítséget igénybe vevő intézmények kész forgatókönyvet kapnak, pontos időbeosztással, mikor érdemes meghirdetni az eseményeket, milyen felületeken mutassák be a könyvtár közösségi tudományos munkáját, a közösségi tudományos projekt kutatóinak a tevékenységét, a már elért eredményeket. Biztosítják a médiumokban való megjelenést, ezzel segítve a közös célt, minél nagyobb igényt kelteni egy-egy projektben való részvételre a társadalom különböző rétegeiben. $\mathrm{Az}$ európai szervezet, a European Citizen Science Association egyelőre még nem indított hasonló kezdeményezést, Európában ezen a téren nem mutatkozik akkora érdeklődés, mint Amerikában. Ugyanakkor az Európai Kutatók Éjszakája az Európai Unió tudományos stratégiájában kulcsszerepet játszó Horizon 2020 kutatási és innovációs keretprogram ${ }^{28}$ alapján valósult meg idáig minden év november utolsó hétvégéjén, bizonyosan folytatódik mind a kutatástámogatás, mind az ismeretterjesztés ezen a téren. A Magyar Tudomány Ünnepét ${ }^{29} 2003$ óta ünneplia Magyar Tudományos Akadémia, amely manapság már nemcsak november 3-ra redukálódik, hanem évek óta már egész novemberben ismeretterjesztő előadások, konferenciák kerülnek megrendezésre az ország nagyvárosaiban, egyetemi központokban a Tudomány Ünnepe kapcsán. Tulajdonképpen a már meglévő állandó eseményekhez lehetne kötni Európában és Magyarországon is a közösségi tudományra felhívó nap, hónap eseményeit. Miért ne lehetne november első hétvégéje a Közösségi Tudomány „Éjszakája”, így egyszerre kapcsolódhatna a Tudomány Ünnepe novemberi eseménysorozatához és a november végi Kutatók Éjszakájához? Az elmúlt évek tapasztalatai azt mutatják, hogy a központilag meghirdetett, központi népszerüsítéssel segített események mindig nagyon látogatottak, jó lehetőség az ismeretterjesztésre és az önkéntesek toborzására.

28 Horizon 2020 rövid bemutatása https://ec.europa.eu/programmes/ horizon2020/sites/horizon2020/files/H2020_HU_KI0213413HUN.pdf (utolsó megtekintés: 2021. 07. 04.)

29 A Magyar Tudomány Ünnepe https://hu.wikipedia.org/wiki/A_magyar_ tudom\%C3\%Alny_\%C3\%BCnnepe (utolsó megtekintés: 2021. 07. 04.) https://mta.hu/tudomanyunnep2020/(utolsó megtekintés: 2021. 03. 13.) 


\section{A KÖZÖSSÉGI TUDOMÁNYOS PROJEKTEK FELÉPÍTÉSE}

Mint minden projekt, a közösségi tudományos projektek is akkor lesznek sikeresek és eredményesek, ha kellőképpen előkészítik, a munkafolyamatokat meghatározzák, a projektben résztvevők pontosan tudják, hogy kinek mi a feladata. A közösségi tudományos projektek meghatározásánál már beszéltünk arról, hogy akkor lehet szó közösségi tudományos projektről, ha a kutatási szakterületen jártas szakember vezeti a projektet, illetve a munkafolyamat különböző fázisaiban, ilyen az önkéntesek munkájának ellenőrzése, szakemberek is részt vesznek. A közösségi tudományos projektek önkéntesei lehetnek a téma iránt érdeklődő egyének vagy a közösség különböző, már összeszokott csoportjai, például iskolai csoport, helyi civil szervezet tagjai. Sok esetben a könyvtárak a két csoport, a szakemberek és az önkéntesek közötti híd, összekötő szerepét töltik be.

Azokban az országokban, ahol a közösségi tudományos projektek bevált módszerként élnek, nemcsak civil szervezetek vállalják fel a tevékenységet, hanem akár kormányzati, állami támogatást is kapnak. Jó példa erre Ausztria; a Zentrum für Citizen Science ${ }^{30}$, mely az Oktatási, Tudományos és Kutatási Minisztérium fenntartása alá tartozik. Nemcsak népszerűsíti a közösségi tudományos projekteket, hanem pénzügyileg is támogatja a különböző közösségi tudományos projektek megvalósulását, és aggregátorként közvetíti az aktuális projekteket. Ausztriában az Österreich forscht ${ }^{31}$ országos szervezetként fogja össze a közösségi tudománnyal foglalkozókat, célja, hogy a közösségi tudományos projektek módszertanát és minőségét fejlesszék, ismertté és elismertebbé tegyék a közösségi tudományos tevékenységet, ezért évenkénti konferenciát is szerveznek.

30 Zentrum für Citizen Science honlapja https://zentrumfuercitizenscience.at/ (utolsó megtekintés: 2021. 07. 04.)

31 Österreich forscht honlap https://www.citizen-science.at/ (utolsó megtekintés: 2021. 07. 04.) 
Az osztrák példa jól mutatja, hogy állami projektekkel, támogatással, sokkal hatékonyabban lehet a kutatókat is érdekeltté tenni, az önkénteseket pedig motiválni. Az Open Science (nyílt tudomány) és ezen belül a közösségi tudomány is mozgalom formájában indult, azonban a tudományos világ nagyon is központosított, és ezzel együtt jár a finanszírozottsága is, akár államilag, akár magántőkével.

Fontos kiemelni, hogy a közösségi tudományos projekteknek is költségvetéssel kell rendelkezniük, befektetés nélkül nem lehet értéket teremteni. A nyílt tudomány és a nyílt hozzáférés kapcsán sokan úgy vélik, hogy „ingyen” van a tudomány, a publikáció, a tudományos eredmény. Úgy vélem, ez a „városi legenda” a tudományos körökben már régen megdőlt. A projektben önkéntesként dolgozók ugyan nem kapnak munkabért, de mint minden munkának, van anyagköltsége, eszközigénye, és nem szabad azt sem elfelejteni, hogy a szakemberek, a kutatók, akik a projektet vezetik, a munkájukat végzik. A Közösségi Régészeti Egyesület is az ásatáshoz szükséges eszközöket biztosítja az önkénteseknek. Ha az ásatás egy forró nyári napon van, akkor sátorról, árnyékról, pihenőhelyről és vízről is gondoskodik a terepen dolgozók számára.

Közösségi tudományos projektek kezdeményezője lehet maga a kutató, kutatócsoport, egy közösség intézményesült képviselete (önkormányzat), civil szféra képviselője (helytörténeti, helyismereti egyesület), helyi közgyűjtemény, a könyvtár, múzeum vagy levéltár és természetesen akár egyéni kezdeményezés is lehet a projekt alapja.

A projekt kezdeményezőjének első lépése a pontos célmeghatározás: mi a vizsgálandó terület, mire vonatkozik a kutatás, milyen előfeltételezésekkel rendelkeznek a kutatók, kik vesznek részt a kutatásban, a hivatásos szakemberekre vonatkozóan is pontos adatokra van szükség. A kutatási program leírásában ki kell emelni az önkéntesek feladatát, mit várunk el az önkéntesektől, van-e feltétele a programhoz való csatlakozásnak. A projekttől függően szükség lehet valamilyen előképzettségre, például adatbevitel esetében számítógépes felhasználói ismeretekkel kell rendelkezniük a jelentkezőknek. 
A tervezés időszakában számba kell venni a projekt eszközigényét is. A szakembereknek és az önkénteseknek is különböző eszközökkel kell dolgozniuk, gondolhatunk ásóra, ecsetre, papírzacskóra, de a legegyszerűbb esetben is jegyzetfüzetre és íróeszközre szinte minden projektnél szükség van. Az európai és amerikai természettudományos közösségi tudományos projektek sok esetben egy „csomagot” adnak át minden önkéntesnek. Gondoljunk például az időjárás-megfigyelésekre, nemcsak jegyzetfüzetet kapnak az önkéntesek, hanem egy előre elkészített kérdéssort kell rendszeresen megválaszolniuk, pont úgy, ahogy 1881-ben Heller Ágost is kitalálta a viharjelzések menetét, ezáltal az adatok összehasonlíthatók lesznek. Ezen kívül a csomag tartalmazhat még különböző mérőeszközöket, például a csapadékméréshez szabványos edényt vagy hőmérőket.

A tervezés időszaka semmiképpen nem hagyható ki, a jól végiggondolt munkamenet segít meghatározni a költségvetést is, amely szintén sarkalatos pontja a sikeres közösségi tudományos projektnek. Miután tudjuk a felmerülő költségeket, meg kell találnunk a forrást is. Nagyon sok finanszírozási forma ismert. Amikor egy kutatóintézettől indul a projekt, akkor az intézmény szokta finanszírozni, és az intézmény biztosítja a megfelelő számú szakember részvételét, munkaidejét és fizetését, az intézmény biztosítja az eszközöket és a projekt eredményeinek közzétételét is. A helyi értékek és érdekek mentén kialakuló közösségi tudományos projekteket általában a helyi önkormányzat vagy egy helyi civil szervezet támogatja anyagilag, de arra is van példa, hogy magánemberek finanszíroznak egy projektet, vagy több érdekelt közösen fizeti a felmerülő költségeket.

Az előre meghatározott költségvetési keret mellett meg kell határozni a projekt idö- és térbeli határait, melyekhez mint mérföldkövekhez igazodhatnak a résztvevők. Az idő- és térbeli meghatározás segíti a szervezőket abban is, hogy felmerjék, megbecsüljék a szükséges erőforrásokat, az önkéntesek számát.

Az első lépések után a projekt „fejlesztési” fázisa következik. A célmeghatározás alapján elkezdődhet a felkészítő anyagok 
összeállítása. Ezek kapcsán érdemes lehetőleg minél átláthatóbb és sokrétűinformációt adni az önkénteseknek, köznyelven, ismeretterjesztő módon leírni a szakterületet, miért fontos a kutatás, hogyan segíthetik az önkéntesek a projektet, mire számítanak a szakemberek, mely kritériumok teljesülése alapján mondható majd sikeresnek a projekt. Szerencsés esetben a projektben könyvtár és könyvtáros is részt vesz, a könyvtári közösségi pontra kerülő szóróanyagok mellett, különböző időpontokban célszerü előadásokat tartani, a könyvtár honlapján is felhívni az érdeklődők figyelmét a lehetőségekre. Amennyiben szükséges, a „fejlesztési” időszakban kell elkészülnie a projekthez használt egyedi szoftvernek, meg kell határozni az adatbevitel módszereit. Irásba kell foglalni a projekthez kapcsolódó protokollokat, etikai szabályzatot. Ebben az időszakban indul meg a toborzás és a szerteágazó marketing munka, amely egyszerre népszerüsíti a közösségi tudományos projektet, a szakterületet és a projektben harmadik félként résztvevő közgyüjteményt.

A projekt megvalósítási időszakában indul az önkéntesek felkészítése, ezek után az önkéntesek, sokszor a szakemberekkel együtt, a tudományos kutatási projektben leírtak alapján végzik a feladatot. Ennek az időszaknak lényeges, kihagyhatatlan része az önkéntesek munkáinak, az adott szakterület szakemberei által végzett, folyamatos ellenőrzése, és visszajelzés küldése az önkénteseknek. Egy közösségi tudományos projekt minden fél számára remek hírverési eszköz, ebben a fázisban a lehető legtöbb alkalommal és legtöbb helyen hírt kell adni a munkáról, a várható eredményekről, a részvevő önkéntesekről, a szakterület helyzetéről és a folyamatokat segítő könyvtárról.

Az elemzések és jelentések időszaka még nem a projekt lezárása. Sokszor ez az időszak hosszabb, mint az adatgyüjtés, ekkor készülnek el az adatelemzések, az eredmények összesítése, esetleg összehasonlítása egy előző projekt eredményeivel, publikálása és értelmezése. Fontos az önkéntesekkel való munka kapcsán kialakult tapasztalatok megfogalmazása és megosztása mind az önkéntesekkel, mind a szakemberekkel. A European Citizen Science Association 
által közreadott 10 alapelv 2. pontja szerint a közösségi tudományos projektek eredménye hiteles tudományos eredmény, amit még biztos sokan és sokáig megkérdőjeleznek a kutatók közül, éppen ezért elengedhetetlen az adott szakma elismert szakmai folyóirataiban nyílt hozzáféréssel publikálni, hangsúlyozva az önkéntesek szerepét és az általuk végzett munkafolyamatokat az egész kutatási projekten belül.

Mivel a közösségi tudomány a nyílt tudomány egyik összetevője, ezért minden esetben a gyüjtött adatokhoz, következtetésekhez szabadon hozzá kell férnie minden érdeklődőnek, akár jártas az adott szakterületen, akár nem.

A projektek lezárása egyértelműen egy összegzés, amelybe minden résztvevőt érdemes bevonni. Ezt sokszor egy-egy konferenciával, kiállítással szokták megvalósítani, ami újabb lehetőséget biztosít a népszerüsítésnek. Más-más perspektívából látja a projekt eredményét a kutató, az önkéntes és a könyvtáros vagy mediátor. Törekedni kell rá, hogy minden résztvevő csoport megszólaljon egy beszámoló kapcsán. A közösségi tudományos projektek nemcsak tudományos szempontból fontosak, érdemes levonni a közösségre gyakorolt hatását is a közös munkának.

\section{HAZAi jó GYAKORLATOK}

A közösségi régészet mint fogalom a 2000 -es évek legelején jelent meg a nemzetközi szakirodalomban. Magyarországon az első közösségi régészettel foglalkozó cikk 2019-ben jelent meg, Rácz Tibor Ákos ${ }^{32}$ tollából. A Pest Megyei Ferenczy Múzeum Központ régészei 2010 óta szerveznek olyan tervásatásokat, melyeken nemcsak régészek, muzeológusok, egyetemi hallgatók vesznek részt, hanem amatőrök is, önkéntes alapon. Az évek során sok tapasztalatra tettek szert. 2019-ben Közösségi Régészet Egyesület néven először megyei hálózat kialakítását

32 Rácz Tibor Ákos, Közösségi Régészet: egy új kutatási eljárás születése, MuzeumCafe, 72(2019), 149-158. https://epa.oszk.hu/03300/03343/00015/pdf/EPA03343_ muzeumcafe_72_149-158.pdf (utolsó megtekintés: 2021. 07. 04.) 
kezdték meg, mely mára országossá nőtte ki magát. Az egyesület célja, hogy a fémkeresős kincsvadászok figyelmét egy sokkal tágabb cél felé fordítsák, a régészeti lelőhelyek örökségvédelmi értékére és a számos régészeti lelet kulturális értékére.

A Közösségi Régészet Egyesület felismerte a közösségben rejlő erőt és lehetőséget, kihasználja a helyi értékek feltárására és megőrzésére irányuló helyi érdekeket. Az elmúlt időszakban önkéntesnek jelentkezők száma szemmel láthatóan megugrott, egyre szerteágazóbb tevékenységekbe lehet bevonni az önkénteseket, nemcsak az ásásba, de a tervezésbe és a döntéshozatalba is. A hobbi fémkeresők csoportjából áttevődött a hangsúly egy-egy lelőhely teljes régészeti feltárására.

Az Egyesület honlapot ${ }^{33}$ üzemeltet, mely sok szempontból mutatja az elmúlt időszak sikereit, a kiforrott együttműködés kereteit. A honlap nemcsak az egyesület tevékenységét, a csatlakozás mikéntjét, tisztviselőit mutatja be, hanem az önkéntesek is lehetőséget kapnak publikálásra, élménybeszámolóra, ezáltal is népszerűsítve a közösségi tudományos projektek sikereit, előnyeit és a bennük rejlő lehetőséget. A honlapon elérhető az aktuális feltárásról egy rövid képes beszámoló, a lezárt kutatásoknál pedig olvasható a résztvevő önkéntesek névsora. $\mathrm{Az}$ értékmentés és értékteremtés az Egyesület stratégiai célkitűzése. Az ásatások során felszínre került leletek, kincsek restaurálására nem minden esetben van anyagi lehetősége a területileg illetékes múzeumnak. Az Egyesület honlapján a „Fogadj örökbe” címszó alatt egy-egy lelet fényképe mellett látható, hogy milyen költséggel jár a restaurálása, amelyre szintén adakozni lehet. A finanszírozók nevét - amennyiben hozzájárulnak -szintén feltüntetik a honlapon.

Az Egyesület egyik kezdeményezése egy nyílt hozzáférésű folyóirat elindítása, LANCEA REGIS címen, melyben közösségi régészeti projekteket vezető régészek által írt szakmai cikkek vannak, egy-egy feltárás és kutatás menetéről.

33 Közösségi Régészeti Egyesület honlapja www.kozossegiregeszet.hu (utolsó megtekintés: 2021. 03. 14.) 
$\mathrm{Az}$ Egyesület rendszeresen tart workshopot, tréninget az egyesületi tagoknak és érdeklődőknek. Az eleinte megyei szintű mozgalom iránt szakmai körökben is egyre nagyobb érdeklődés tapasztalható, már minden megyéből csatlakozott régész az egyesület tevékenységéhez. $\mathrm{Az}$ egyesület régészei nagy hangsúlyt és energiát fektetnek az önkéntesek megtartásába, motiválásába, szerephez juttatására. Folyamatosan lehetőséget biztosítanak az önkénteseknek az ásatásokról szóló beszámolók megírására és a workshopokon is állandó előadók. Az önkéntesek csatlakozása szabályozott, az egyesület alapelveit, mely nagyban hasonlít a múzeumi etikai kódexre, a kulturális örökség múzeumi megőrzését, minden csatlakozónak el kell fogadni. A lemorzsolódás természetes folyamat, egy-egy terület feltárásánál jellemzően a helyi önkéntesek száma megnő, azonban, sajnos, arra is volt példa az elmúlt időszakban, hogy egy-egy önkéntest kizártak az egyesületből az etikátlan viselkedése miatt.

A Közösségi Régészeti Egyesült a közösségi tudomány jó példája, minden fórumot és lehetőséget megragadnak munkájuk láttatására és eredményeik elismertetésére. Munkájuk és a feltárt kincsek bemutatására 2021. június 19-én nyílt kiállítás Szentendrén.

A múzeumi területen szintén kimagasló a szentendrei Skanzen közösségi tudományos tevékenysége, annak ellenére, hogy a kifejezést nem használják. A koronavírus-járvány okozta első lezárás alatt, 2020 tavaszán hirdette meg a Határtörténetek felhívását a szabadtéri múzeum. A projekt a Határtalan Skanzen ${ }^{34}$ tematikus évhez kapcsolódott, mely a Trianon utáni időszak hétköznapjaival foglalkozott. A projekt során a látogatók által elküldött képeket, történeteket gyüjtötték az elmúlt száz év határátlépéséről, így az oral history műfajt vegyítették a Citizen Science-szel. Az eredmény nemcsak egy virtuális kiállítás, hanem a kordokumentumok alapján egy széles társadalmi réteg életstílusát, hozzáállását, szociális helyzetét lehet rekonstruálni szakemberek bevonásával.

34 Szabadtéri Néprajzi Múzeum: Skanzen honlapja https://skanzen.hu/hu/askanzen/projektek/hatartortenetek-felhivas (utolsó megtekintés: 2021. 03. 14.) 
A szentendrei Skanzen az elmúlt időszakban egyre inkább társadalmasítja a kiállításokat, számos felhívást tesznek közzé, a múzeum látogatói formálják a kiállítások tematikáját. A Cselekvő Közösségek 2016-2019 között futó EFOP 35 pályázat keretében országos programot indítottak a Skanzen vezetésével, mely kifejezetten a társadalmi aktivitás növelésére, a közösségi szerepvállalás erősítésére fókuszált, hogyan tudják a közgyüjtemények céltudatosabban és hatékonyabban bevonni az adott közösséget a saját munkájukba. A projekt eredménye sok szempontból a jövőben mutatkozik meg, mennyire lesz hatékony a projekt során kialakított országos kulturális közösségfejlesztő mentorhálózat. A Cselekvő Közösségek projekt tanulságait azonban mindenképpen érdemes megvizsgálni, hiszen éppen az aktív közösség az alapja a közösségi tudományos projekteknek.

A külföldi példák alapján megállapítható, hogy általánosságban a természettudományos projektek többségben vannak. Mivel hazánkban sem az önkéntességnek, sem a közösségi tudománynak, de még a nyílt tudománynak és a nyílt hozzáférésnek sincs jogszabályi háttere vagy akár civil kezdeményezésen alapuló egyesülete, ezért igazából nem is lehet számszerüsíteni a megvalósult vagy müködő közösségi tudományos projekteket. Hagyatkozva a külföldi aggregátorokra, az egyesületek által közzétett projektekre és a napi tapasztalatainkra, mondhatjuk, hogy hazánkban is jelentős számban vannak és népszerűek a természettudományos projektek. Az önkéntesek bevonásával történő tudományos projektek legkiemelkedőbb hazai példája a Nemzeti Biodiverzitás-monitorozó Rendszer keretein belül kialakított vadonleso.hu oldal, melyet magyarországi példaként említ a legfrissebb nemzetközi szakirodalom is. ${ }^{36}$ A Nemzeti Biodiverzitás-monitorozó Rendszer a Vidékfejlesztési Minisztérium, Természetmegőrzési

35 https://skanzen.hu/hu/a-skanzen/intezmenyeink/cselekvo-kozossegek(utolsó megtekintés: 2021. 03. 14.) https://cselekvokozossegek.hu/(utolsó megtekintés: 2021. 03. 14.)

36 The Science of Citizen Science, ed. Vohland, Katrin, Land-Zandstra, Anne, Ceccaroni, Luigi, Lemmens, Rob, Perelló, Josep, Ponti, Marisa, Samson, Roeland, Wagenknecht, Katherin, Springer, 2011, 41. https://doi.org/10.1007/978-3-030-58278-4 (utolsó megtekintés: 2021. 03. 14.) 
Főosztály által koordinált program, melynek keretében hosszútávú megfigyeléseket végeznek, hogy minél kevesebb állat- és növényfaj kerüljön veszélyeztetett helyzetbe. A vadonleso.hu ${ }^{37}$ weboldalon és a hozzá kapcsolódó mobilalkalmazáson az önkéntesek a közvetlen környezetükben észlelt növényeket és állatokat tudják regisztrálni. A honlap felsorolja, bemutatja és leírást ad 10 állatfajról és 8 növényről. A honlapon regisztrált önkéntesek térképen jelölhetik be az adott faj aktuális előfordulását, és részletes adatlapot töltenek ki. A feltöltött adatok szakmai ellenőrzést követően egy hivatásos természetvédelem adatbázisába, a Természetvédelmi Információs Rendszerbe (TIR) kerülnek, ezzel az önkéntesek nagy segítséget nyújtanak egy-egy faj megőrzésében. A közösségi tudományos projekt minden kritériumának megfelel a Vadonleső program, önkénteseikről is rendszeresen megemlékeznek, a honlapjukon közzéteszik egy-egy időszak legtöbbet feltöltő megfigyelőt.

Számos közösségi tudományos projekt éppen azért indul el, mert az érdeklődők, akár adott település, közösség állampolgárai kezdeményezik a kutatást. Ilyen a 2021. júniusában Eger környékén élők összefogása, hogy feltárják a Nagy-Eged hegyen lévő egykori kápolnát ${ }^{38}$. A projektben nyugdíjas matematikatanár, művészettörténész, régészek, levéltárosok, a Dobó István Vármúzeum és az Egererdő Zrt. több munkatársai is részt vesznek.

A Kézai Simon Program pedig már állami kezdeményezés alapján jött létre a Digitális Jólét programhoz kapcsolódva. „A Program küldetése olyan országos mozgalom létrehozása, amelynek célja digitálisan megőrizni a régi, analóg technológiával fotókon rögzített emlékeket és családi történeteket. A Program keretén belül a fényképek és dokumentumok digitalizálását, valamint online albumba rendezését a fotók tulajdonosai webes felületen, ingyenes mobilapplikáció

37 Vadonleső honlap https://vadonleso.hu/ (utolsó megtekintés: 2021. 03. 14.)

38 Elfeledett titkokat rejt az egri Nagy-Eged hegyi kápolna, Magyar Nemzet, 2021. 06. 16. https://www.heol.hu/kozelet/helyi-kozelet/elfeledett-titkokat-rejt-az-egrinagy-eged-hegyi-kapolna-3719399/(utolsó megtekintés: 2021. 07. 03.) 
segítségével, illetve az ország 25 pontján a Digitális Jólét Program Hálózat Kézai Pontjain, könyvtárakban, levéltárakban tudják elvégezni ingyenesen 100 kép erejéig. A Program szeretné ezeket az emlékeket, valamint a hozzájuk kapcsolódó történeteket megőrizni az utókor számára, a kollektív emlékezet részévé tenni, ezáltal lehetővé téve a nemzettörténeti elemzések kiegészítését, kutatások támogatását." ${ }^{39}$

Ma már az önkéntesek „alkalmazása”, főleg a kulturális intézményekben teljesen bevett és megszokott dolog. Azonban látnunk kell, hogy a közösségi tudomány más, eltér az általános önkéntesi munkától. Minden esetben konkrét projektekben gondolkozunk, mely meghatározott ideig tart, mindig az adott szakterület szakembere irányítja és ellenőrzi az adatokat, munkafolyamatot. Az önkéntesek lelkesedése kézzel fogható, hiszen szabadidejüket áldozzák fel egy adott ügy érdekében. A résztvevő önkéntesek életkorát vagy korfáját ugyan még egy közösségi tudományos cikk sem dokumentálta, de az ismert projektekbe jellemzően a gyerekek/fiatalok és a nyugdíjasok jelentkeznek önkéntesnek, akiknek az időbeosztása és elfoglaltsága lehetővé teszi a rugalmasságot. Az önkéntesek a csatlakozással egy új közösség tagjai lesznek, akár a valóságban, akár virtuálisan találkoznak, befolyással vannak egymásra. A résztvevő önkéntesek érdeklődőek, nyitottak az új ismeretekre, első kézből kaphatnak információt a kutatásról. A visszacsatolások alapján érezhetik, hogy a társadalom, közösség hasznos tagjai, a közösségi tudományos projektben való részvétellel nemcsak saját ismereteik gyarapodnak, hanem maguk is értéket teremtenek.

39 Kézai Simon Program honlapja https://kezai.hu/about (utolsó megtekintés: 2021. 07. 04.) 


\section{FelHASZnÁlt IRODALOM}

Bonter, David N., Cooper, Caren B., Data validation in citizen science: a case study from Project FeederWatch, Frontiers in Ecology and the Environment, Vol. 10, issue 6. Forrás: https://doi.org/10.1890/110273

Causer, Tim, Grint, Kris, Sichani, Anna-Maria, Terras, Melissa, 'Making such bargain': Transcribe Bentham and the quality and cost-effectiveness of crowdsourced transcription, Digital Scholarship in the Humanities, Vol. 33, Issue 3, September 2018, 467-487.

Forrás: https://doi.org/10.1093/llc/fqx064

Citizen Science, Innovation in Open Science, Society and Policy, ed. НескеR, Susanne, Haklay, Muki, Bowser, Anne, Makuch, Zen, Vogel, Johannes, Bonn, Aletta, London, UCL Press, 2018, 580.

Forrás: https://www.uclpress.co.uk/products/107613

Conen, Cynthia M., Cheney, Liz, Khue Duong, Lea, Ben, Unno, Zoe Pettway, Identifying Opportunities in Citizen Science for Academic Libraries, Issues in Science and Technology Librarianship, 2015 winter, (79). Forrás: https://doi.org/10.5062/F4BR8Q66

Holl András, Amatőr kibertudomány, Természet Világa, 201l. december, 571-574.

Ignat, Tiberius et al., Merry work: libraries and citizen science, Insights, 31(2019), 35. Forrás: http://doi.org/10.1629/uksg.431

Ignat, Tiberius, Cavalier, Darlene, Nickerson, Caroline, Citizen Science and Libraries: Waltzing towards a collaboration, Mitteilungen der Vereinigung Österreichischer Bibliothekarinnen und Bibliothekare, 72(2019), 328-336. Forrás: https://doi.org/10.31263/voebm.v72i2.3047 
Monok István, Könyvtári(?) problémák, Budapest, MTA KIK, 2020 (A Magyar Tudományos Akadémia Könyvtárának közleményei. Új sorozat, 41.)

https://doi.org/10.36820/MTAKIK.KOZL.2020.KONYVTAR

Moyle, Martin, Tonra, Justin, Wallace, Valerie, Manuscript Transcription by Crowdsourcing: Transcribe Bentham, LIBER Quarterly, 20(3-4), 347-356.

Forrás: http://doi.org/10.18352/lq.7999

RÁcz Tibor Ákos, Közösségi régészet: Egy új kutatási eljárás születése, MúzeumCafé, 72, 4(2019), 13. évf., 148-157.

Forrás: https://epa.oszk.hu/03300/03343/00015/pdf/EPA03343_

muzeumcafe_72_149-158.pdf

Wiggins, Andrea, Newman, Greg, Stevenson, Robert D., Crowston, Kevin, Mechanisms for Data Quality and Validation in Citizen Science, 2011 IEEE Seventh International Conference on e-Science Workshops, Stockholm, 2011, 14-19.

Forrás: https://doi.org/10.1111/cobi.12706 


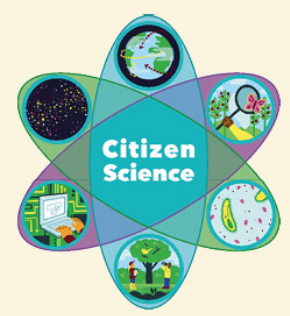

KÖZÖSSÉGI TUDOMÁNY

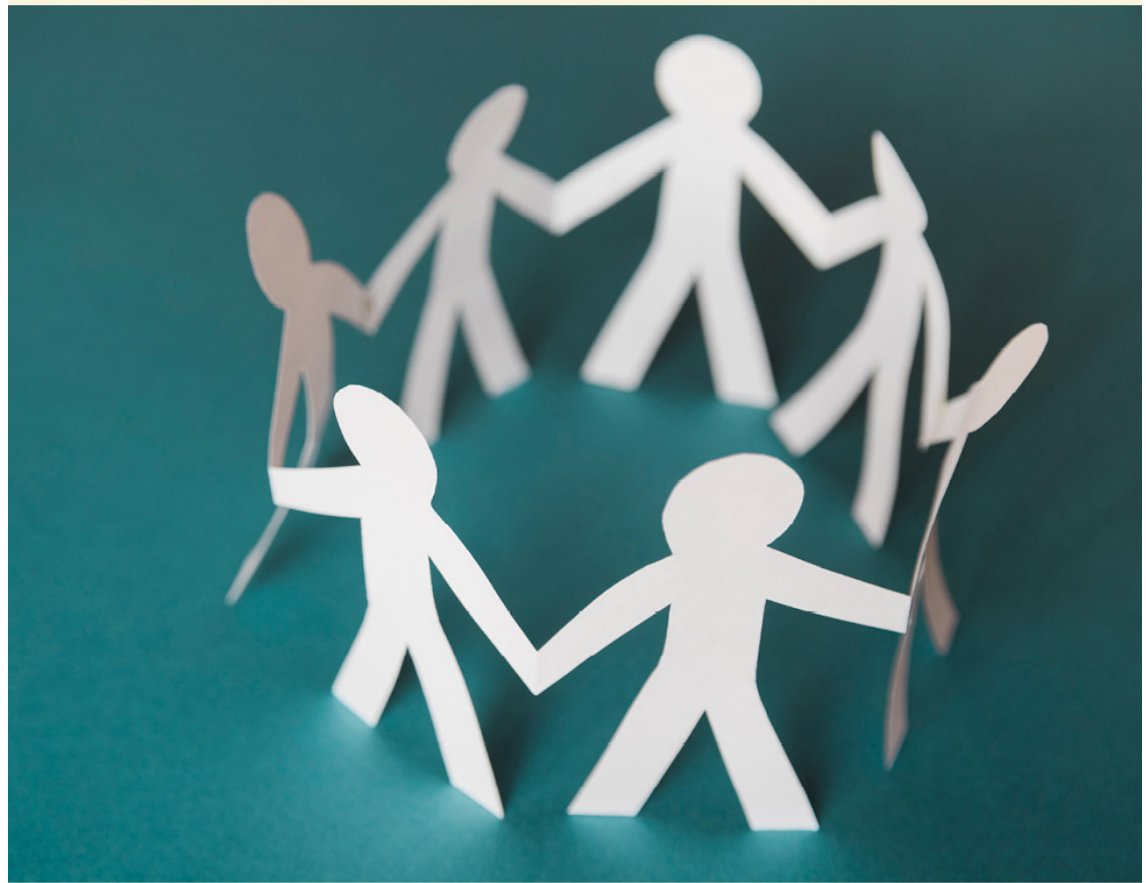




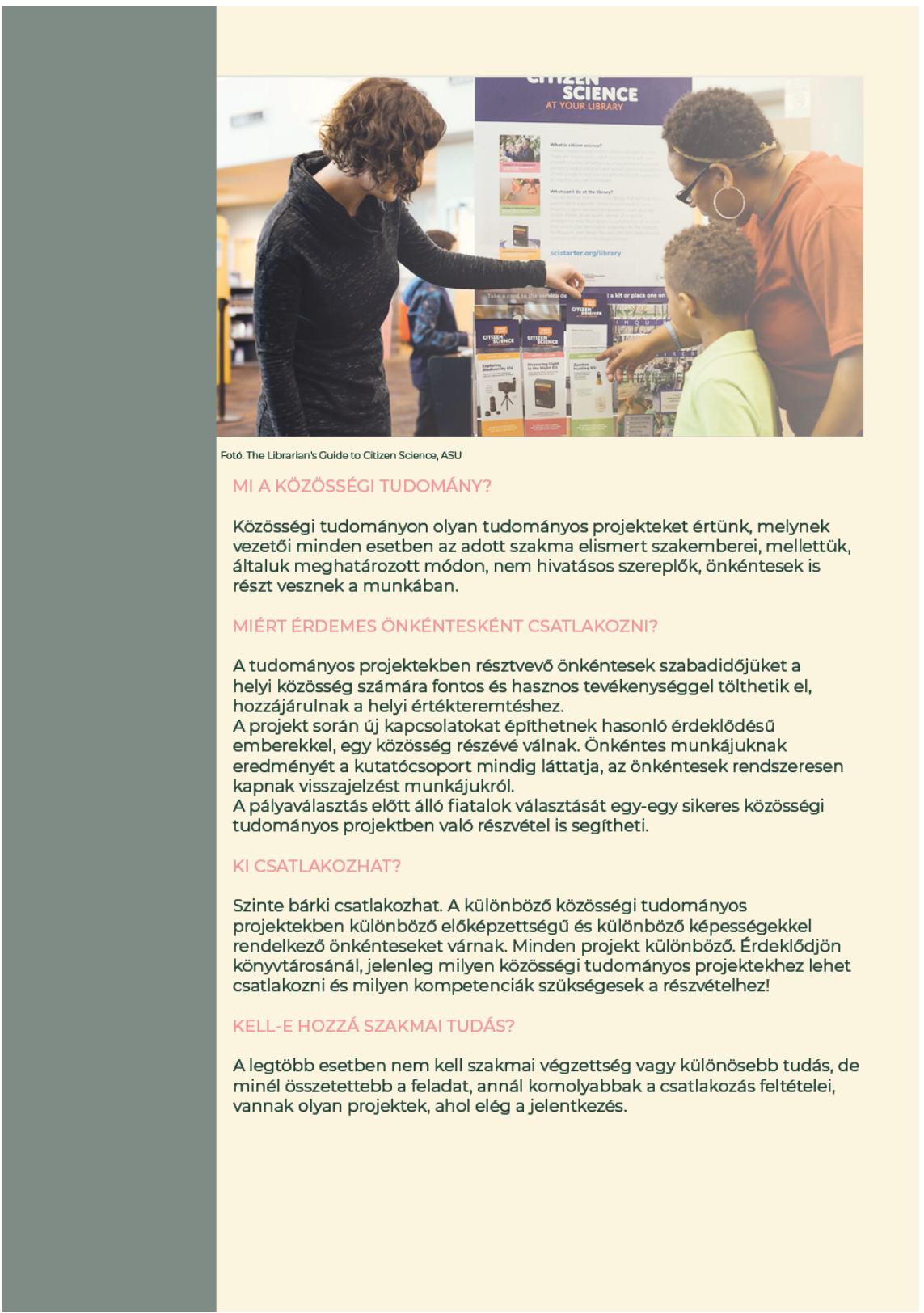




\section{MILYEN JUTTATÁSOKAT KAPHATOK?}

Általában a közösségi tudományos projektek költségvetése szükös, nem jellemzó, hogy bármilyen juttatást kapnának az önkéntesek, azonban a projektben résztvevơk mindig kapnak visszajelzést a munkájukról. A közösségi tudományos projektekben részt vevő önkénteseket köszönetnyilvánítás és elismerés illeti meg a projekt eredményeinek közzétételekor és a publikációkban.

\section{MILYEN KÖTELESSÉGEIM VANNAK ÖNKÉNTESKÉNT?}

\begin{abstract}
A közösségi tudományos projekt vezetōje gondoskodik a tevékenység ellátásához szükséges irányításról, tájékoztatásról, amennyiben szükséges, az önkéntesek képzéséről. A projekt vezetóje által meghatározott etikai és szakmai szabályokat be kell tartani a munka eredményessége és a közösségi tudományos projektben résztvevő́k érdekében. A közösségi tudományos projektekhez kapcsolódók nyilatkoznak a szabályok, elö́rások, módszerek betartásáról.
\end{abstract}

\section{HOGYAN CSATLAKOZHATOK?}

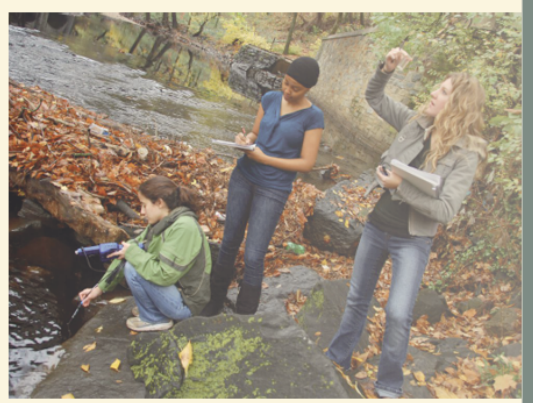

Foto: Jackie Karsten, National Geographic

A különbözó közösségi tudományos projektek más és más csatlakozási feltételt szabhatnak. Érdeklödjön könyvtárosánál a lehetőségekről!

\section{HOGYAN VESZNEK RÉSZT A KÖNYVTÁRAK A KÖZÖSSÉGI TUDOMÁNYBAN?}

A könyvtárak a kutatócsoport és az önkéntesek között moderátorként, információs bázisként vesznek részt a projektekben. A programhoz kapcsolódó könyvtárakban az olvasókkal kapcsolatot tartó könyvtárosok tájékoztatást nyújtanak a településen, régióban elérhetớ közösségi tudományos projektekről, összekötik az érdeklödóket és a szakembereket. Sok esetben a könyvtárosok tartják a projekthez kapcsolódó felkészító elóadásokat, információt és segítséget nyújtanak az önkénteseknek. A könyvtáraknak lehető́ségük van saját közösségi tudományos kutatást indítani, ekkor a könyvtár szakemberei a kutatás vezetói.

\section{MIÉRT ÉRI MEG A KUTATÓKNAK KÖZÖSSÉGI TUDOMÁNYOS PROJEKTET SZERVEZNI?}

A közösségi tudományos projektek legfóbb haszna, hogy jelentős számú érdeklődőt lehet megszólitani, sok önkéntessel dolgozhatnak a kutatók, f́gy általában egyegy megfigyelés, kísérlet, projekt hamarabb befejezódik, és/vagy sokkal nagyobb merítésre tehetnek szert. Minél többen csatlakoznak a projekthez, annál többen beszélnek róla, az adott tudományterület népszerüsége és ismertsége nó. Az önkéntesek bekapcsolásával egy új, megbízható reklámfelület nyílik a szakma számára. 


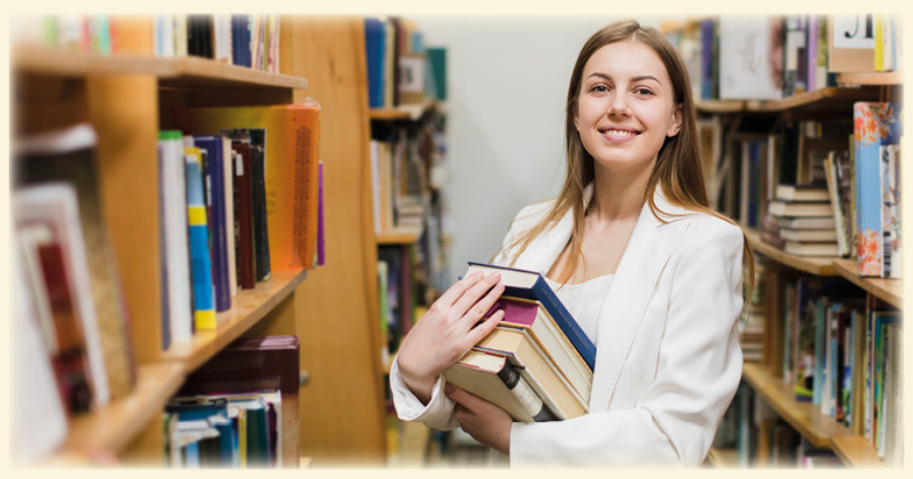

Amennyiben felkeltettük az érdeklődését, látogassa meg a könyvtár honlapját, kérdezze meg könyvtárosát a helyi, regionális közösségi tudományos projektekről!



Borttofotok: Freepikcom 



\title{
What MOtivates us to DEVElop the Focus on Open SCIENCE SERIES?
}

\author{
Tiberius IGNAT
}

Open Science describes the current transition in how research is undertaken, how the outputs are stored and disseminated, how researchers collaborate, how success is measured and how researchers are rewarded for more transparent and collaborative approaches. Open Science has the potential to transform the research landscape. This potential has been successfully tested - if only that - during pandemic times.

In 2015, Scientific Knowledge Services (SKS) together with the Library of the University College London (UCL) started an initiative of organising a series of events that aimed to discuss the principles of Open Science at the local level. At that time, it was a significant level of conversation about Open Science at international conferences, but less than necessary at the level of organisations. Moreover, the international supporters of Open Science were more focused on activism while the practical implementations were rare. We couldn't identify consistent events dedicated to Open Science at the local level, at that time. At best, this new approach for research was making a frail presence in conferences dedicated to other topics of research administration and support. Therefore, we thought that building up a series of events focused on Open Science and bringing the conversation at the local level, sounds like a good idea.

Supporting Open Science wasn't an obvious route for Scientific Knowledge Services. As an academic content provider, we represented (and still do) publishers and other organisations that sell their content under a business model which was almost entirely based on subscriptions. Changes were underway, but this was the most common situation in 2015. Our many years of membership in LIBER (The European Association of Research Libraries) gave us a better 
understanding of the research culture, especially how research is funded, evaluated, supported and what are the expectations from research organisations, at the European level.

We were convinced that fundamental research should move from a competitive landscape measured with proxy indicators to a new architecture that includes precompetitive collaborations at its heart. Applied research, engineering, drug development and many other innovation fronts have plenty of reasons to develop a competitive environment, but the fundamental research should be run on different principles. It is a knowledge layer that needs to be available to the entire research community and - to a large extent - to the broader population.

Even today, 7 years later and 33 chapters away from our first Focus on Open Science event, we feel that a part of the scholarly communication community still asks why SKS got involved in such an endeavour. What is the secret ingredient that keeps us motivated? We respond to that by defending the role of private initiatives in the development of a better world. As we will see, Open Science is first of all a cultural change. It goes to the core of research which was based for centuries on a culture of secrecy. Such a change - from secrecy to openness - can't be made just by a part of our society. It is a complex transformation where everyone should play a role - including private companies - and SKS humbly thinks that we can contribute to transforming research into a more transparent, trustful and participative process. Building a better world is neither the burden, nor the prerogative of the public or non-governmental institutions. On the contrary, it is the responsibility of all of us.

The Focus on Open Science series is not the only venue where we make an effort that contributes to the cultural change in research. For example, we created a workshop to the prestigious OAI Conference (CERN-University of Geneva) in 2019 to discuss how to rightly balance collaboration and competition in research and we presented our proposals at annual conferences like UKSG (UK Serials Group), 
ECSA (European Citizen Science Association) and LIBER to convince larger audiences that every pillar of Open Science matters (including Citizen Science).

Before continuing to present the experience we built during the 7 years of Focus on Open Science (counting on/still counting), we are presenting here some of our views on Open Science, trying to make it clear to the readers of this volume why we are so engaged in this cultural change.

Ideally, research is building an economy of trust in which evidence represents the currency. Researchers seek to find new evidence about nature and society and exchange such evidence within the system (e.g. for technology transfer, for research assessment, for career development) and outside the system (e.g. with policymakers, funders, journalists, schools, etc.). The evidence itself is endorsed by peer-review, a centuries-old process in which researchers discuss the scientific conclusions in expert conversations. There's no doubt that building trust and exchanging evidence requires great transparency.

On the other hand, our society is not designed to grant trust. No reasonable person expects to obtain trust just by asking for it. Our society is set in such a way in which individuals and organisations work hard to acquire the confidence of others. At the same time, the entire society requires evidence and demonstration before establishing trust.

In less words, research requires trust, but trust is obtained hard. We, at SKS, remain hard to be convinced that perpetuating a culture of secrecy for the field of fundamental research is making the research ecosystem run smoothly. If it doesn't run smoothly, the research system is slow and incapable of matching societal needs.

It is worth mentioning here a front that is less developed by the research community, at the global level. The researchers are at best able to establish new evidence. Such evidence represents current 
understanding about, for example, a phenomenon, historical event, behaviour, etc. Researchers are not in the position to discover the ultimate truth about such elements of their investigations. They only discover, discuss and establish new evidence. This is why it is very common that current research contradicts past evidence. This situation is not sufficiently explained and understood by the rest of society. Missing such a fundamental building block, trust in research will always suffer because our society could easily confuse research progress (new evidence) with a lack of consistency (contradicting past evidence). This is a typical area for Open Science, as a new culture, to engage in the change. Connecting science with society is usually tackled through Citizen Science, but other pillars of Open Science could make a great contribution, too.

Equally important, the quality in research should raise and not decrease as we move to more transparency and accelerated discoveries. Some Open Science activists believe that the quality of research is safeguarded by self-regulatory mechanisms that are developed unmediated in an "open" environment. We have a different opinion. With the rise of misinformation, disinformation and algorithmic persuasion (machines persuading humans) we identify as a high risk the idea of looking for self-regulation in Open Science, to increase the quality of research processes. Open Science offers the prospect of full disclosure and accelerated discoveries, but alone, it doesn't offer a solution to increase the quality of research. It should remain attached to certain principles (like peer-review, reproducibility and others) in order to responsibly serve societal needs.

Open approaches were introduced in science in the sixteenth and seventeenth centuries. Before that, a number of elements (or the lack of them) encouraged a situation in which knowledge was only available to a small group of people. It was typical for the Pythagorean and Aristotelian traditions to share knowledge exclusively with elite disciples. As the Oxford Companion to the History of Modern Science notes, "the hermetic philosophy of the Renaissance reserved the secrets 
of nature for initiates in a similar way as craft techniques were locked in the artisan's workshops. In the same period, the absence of intellectual property rights was a great barrier that determined the engineers and inventors to keep their work unpublished or secretly preserved".

The scientific revolution changed that status for knowledge. The newly invented printing press made possible a wider availability of text and knowledge. Italian city-states developed patent laws in the fifteenth century. The seventeenth century brought to the world the scientific societies (Royal Society of London and the Académie Royale des Sciences in Paris) that provided the practical avenue of publication through their journals and promoted the idea that researchers communicate their work in communities of peers ${ }^{1}$.

Against all those new open approaches to knowledge the culture of secrecy is still very much present in research. Making knowledge available is simply not enough to create transparency in research. This culture of secrecy which we challenge is preserved today through 3 vectors ${ }^{2}$ :

1. personal secrecy, motivated by an unjust rewards systems, mainly based on proxy indicators, and by the informal "reputation economy" of research (some call it "research vanity");

2. industrial secrecy which is stimulated by the possible rewards for the ownership of discoveries;

3. military and security interests for which research activities have always delivered a competitive edge.

Open Science represents a different culture to the secrecy of science and should be considered similar in size to the changes of the seventeenth century. But it is no less difficult to produce this cultural change than

1 The Oxford Companion to the History of Modern Science https://www.oxfordreference.com/view/10.1093/ acref/9780195112290.001.0001/acref-9780195112290

2 idem 
it was 500 years ago, therefore it's important to understand its real challenges and opportunities.

Although science became increasingly open, beginning with the seventeenth century, it is only lately that "Open Science" became a concept that promotes more transparency in science. Here is a short evolution of this concept, in a chronological presentation that doesn't pretend to be comprehensive:

- 1998: Prof. Steve Man from the University of Toronto coined the term "Open Science" as a possible solution to address the need for truth and open disclosure ${ }^{3}$.

- 2012: The Royal Society publishes Final report - Science as an open enterprise led by Regius Prof. Geoffrey Boulton ${ }^{4}$

- 2013: Two critical articles were published by The Economist in October 2013 to disapprove the lack of transparency in research:

- Trouble at the $l a b^{5}$

a How science goes wrong ${ }^{6}$

- 2015-2016: Nature's How Scientists Fool Themselves ${ }^{7}$ and the 1,500 scientists lift the lid on reproducibility ${ }^{8}$ were published 2 years after The Economist critiques;

- 2016: The European Council's The transition towards an Open Science system $^{9}$ was adopted in 2016. It represented the next step of the public consultation Science 2.0: science in transition ${ }^{10}$ which is hard to access today on the European Commission's servers (an

3 Mann, S., Janzen, R., Rampersad, V., Huang, J., Ba, L. J., "SQUeAKeys": A friction idiophone, for physical interaction with mobile devices," 2015 IEEE Games Entertainment Media Conference (GEM), 2015, 1-4, DOI:

https://doi.org/10.1109/GEM.2015.7377235

4 https://royalsociety.org/-/media/policy/projects/sape/2012-06-20-saoe.pdf

5 https://www.economist.com/briefing/2013/10/18/trouble-at-the-lab

6 https://www.economist.com/leaders/2013/10/21/how-science-goes-wrong

7 https://www.nature.com/articles/526182a

8 https://www.nature.com/articles/533452a

9 https://data.consilium.europa.eu/doc/document/ST-9526-2016-INIT/en/pdf

10 https://ec.europa.eu/digital-single-market/en/news/science-20-sciencetransition 
example of bad practice of Open Science, in which the "record preservation" practice in policy commons was left behind);

- 2020: The European Commission's expert group "Open Science Policy Platform”, led by Prof. Eva Menez from the University Carol III de Madrid published its final report which includes a valuable set of recommendations: Progress on open science: Towards a shared research knowledge system: final report of the open science policy platform ${ }^{11}$.

Today, the European research stakeholders tend to accept the description of Open Science given by the European Commission when it started to work close with two expert groups (the Open Science Policy Platform and the Horizon 2020 Commission Expert Group on Indicators for Researchers' engagement with Open Science) ${ }^{12}$.

The eight ambitions of the European Commission became the eight pillars of Open Science that still define the movement today in Europe:

1. FAIR Data,

2. Research Integrity,

3. Next Generation Metrics,

4. Future of Scholarly Communication,

5. Citizen Science,

6. Education and Skills,

7. Rewards and Initiatives,

8. The European Open Science Cloud.

It is worth noting that 2021 opens a new era for research ambitions. The COVID-19 pandemic, climate crises, the steps back in globalisation and an increasingly tense situation for securing economic dominance between USA and China made governments more aware of the potential of scientific outbreaks. We are now only 9 years away from measuring

11 https://op.europa.eu/en/publication-detail/-/publication/d36f8071-99bdllea-aac4-0laa75ed7lal

12 https://ec.europa.eu/info/research-and-innovation/strategy/ strategy-2020-2024/our-digital-future/open-science_en 
the success of the United Nation's Sustainable Development Goals (SDG) programme which poses goals that are harder than ever to be reached (by 2030). Some governments are looking to replicate the scientific leap of the $60 \mathrm{~s}^{13}$ and this may have an unpredictable impact on the development of Open Science. On the other hand, UNESCO has drafted a set of recommendations to their members which is expected to be adopted in November 2021. Whether the changing culture of research will continue to head toward Open Science or science will shift to something else, the need for increased transparency to the inner parts of discovery remains a basic need. These developments make us both optimistic and concerned about the future of Open Science.

Finally, the readers of this chapter are encouraged to search and continuously update themselves with the variety of national and international strategies for industry ${ }^{14}$, healthcare ${ }^{15}$ and for defence ${ }^{16}$ and to place the Open Science transformation in such larger contexts of heralded ambitions.

\section{Focus on Open Science: A Series dedicated to SANe change}

When we decided to invest and develop a series of events dedicated to Open Science, we strongly believed that the Open Science movement started as a vision, aiming to address matters like research reproducibility and access to the results of publicly-funded research. We saw that the vision was generally welcomed by academic and research institutions and benefited from a great advocacy movement. At the same time, we were convinced that it was the right time to start building on practice and effective management. Moving from vision and activism to designed advocacy and management represented

13 https://www.economist.com/science-and-technology/2021/06/03/a-growingnumber-of-governments-hope-to-clone-americas-darpa

14 for EU: https://ec.europa.eu/info/strategy/priorities-2019-2024/europe-fitdigital-age/european-industrial-strategy_en

15 for UK: https://ukhealthcare.uky.edu/strategic-plan-2025

16 for EU: https://eeas.europa.eu/topics/common-security-and-defence-policycsdp_en 
for us the needed step to see Open Science in practice, confronted and validated by research communities. We gave great respect to the determination of policymakers and the enthusiasm and support of research administrators to introduce Open Science, but at the same time we knew that the ultimate game changers are the researchers and their communities. And this is what we insisted on: to have the deep conversation of Open Science carried on to the local research communities. Many of our chapters were organised in collaboration with research libraries and we insisted they reach their researchers (readers) and invited them to the series, including both groups: supporters and scepticals of Open Science. Listening and understanding each one's opinion is a key factor to shape the implementation path of this new research approach.

It is generally accepted in Europe that research should be as open as possible and as closed as necessary. Therefore, understanding the dynamic border between the two is one of the most important tasks for practitioners, whether they belong to funders, research organisations, their partners or researchers themselves. Yet, this borderline is not sufficiently explored. Guidelines based on feedback and learning from practice should be created sooner rather than later.

Organising the Focus on Open Science series, we learned that this innovative approach to research has further potential: to address existing inequalities and matters like inclusivity, ethics, better assessment or the missing links between science and society or to re-shape public-private partnerships.

But all these tasks and ambitions are hard to be managed without bold leadership, endurance and sometimes suffering. Although we like to believe that Open Science could deliver immediate and positive results, to uncover a road of discoveries that has never been seen before, the reality that we learned by meeting so many research communities is that Open Science is a difficult, costly and sometimes unpredicted journey. We've noticed that the opportunities it poses are clear and generally similar 
across disciplines and research communities, but the challenges are more diverse and most likely to be overlooked, especially in the bottomup approaches. It is on the leader of institutions to show determination and overarching approaches to support the implementation and the sustainability of this new culture. Lab-created solutions proved to be innovative and sometimes very practical, but without exception they met the struggle of sustainability. They need to gain support from the top management of institutions, to attract human talent and expertise and to secure development funds that exceed project cycles.

We continue to believe that by organising the Focus on Open Science Series in various European communities, we contribute to design local roadmaps for practical and responsible implementation of Open Science.

Soon after our first chapter (Ljubljana, 2015; organised with CTK Ljubljana), we decided to form a Steering Committee to help us keep the right course and tackle the most relevant topics for research communities across regions. Our current Steering Committee has the following members:

1. Dr Paul Ayris, Pro-Vice-Provost (UCL Library Services), Chief Executive, UCL Press, co-Chair of the LERU INFO Community (League of European Research Universities).

2. Frank Manista, European Open Science Manager, Jisc, UK.

3. Jeannette Frey, Director of BCU Lausanne and President of LIBER (Association of European Research Libraries).

4. Colleen Campbell, Open Access 2020 Initiative, Max Planck Digital Library.

5. Dr Ignasi Labastida i Juan, Head of the Research and Innovation Unit of the CRAI at the University of Barcelona (Learning and Research Resources Centre).

6. Dr Tiberius Ignat, Director of Scientific Knowledge Services.

7. Additionally, our local partners will be able to delegate a member to join our Steering Committee with reference to the respective event that will take place in their country. 
For the same reason, we approached LIBER in 2016 and agreed in 2017 on collaborating on this series, promoting each one's effort to communicate the opportunities and challenges of Open Science.

We trust that collaborating with such prestigious institutions, with a proven record of supporting Open Science, allow the series of Focus on Open Science events to remain relevant. We deeply understand that the real-life transformation is posing unforeseen challenges that could be better answered if a strong bond exists between research performing organisations, funders, research support organisations and offices and the Focus on Open Science series.

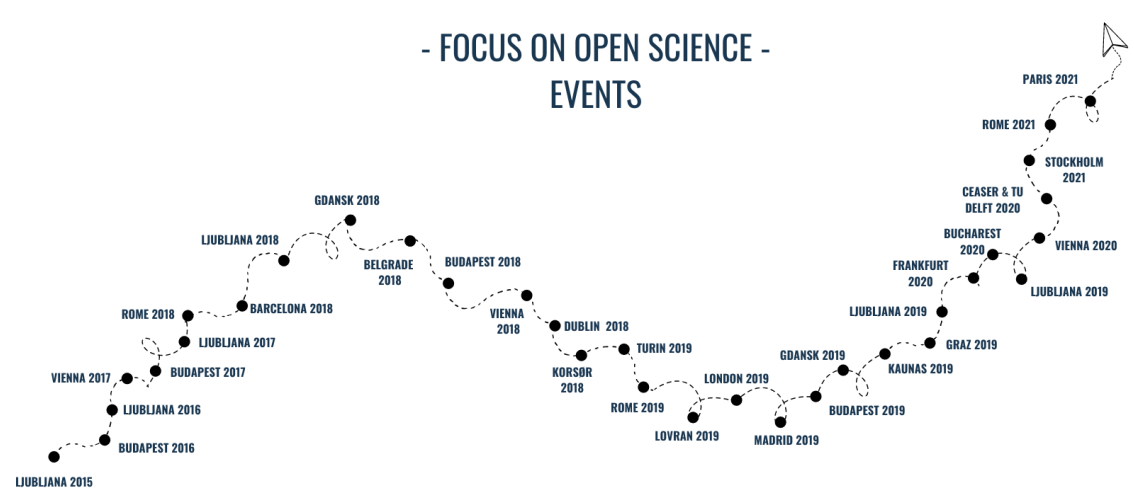

Figure 1. An illustration of all Focus on Open Science events between 2015-2021. Updated: August 2021

During our events, we typically emphasize the research practices and discuss the role of research organisations to support this transition, both acting locally and internationally. 
Starting in 2019, the results of the workshops were captured in formal reports. These reports are intended to be used by all involved partners (not only by organisers), to advance the implementation of Open Science in their communities and their own institutions.

The language of these events is English, but we encourage the audience to pose their questions in their own language if it's easier. To make this work, we received the great support of the audience so far, to translate the questions to the panelists.

The events' format offers both on-the-spot interactions and future networking opportunities. The interactive part has been particularly increased with the transition to "online by default". The online platform is easy to use, without the need to install complicated software or create additional accounts. It offers networking opportunities similar to physical events, including one-to-one videos, while the participants remain in control of deciding with whom to interact. This is probably not the best place to describe the detailed arrangements of the online platform as a successor of the physical events' format, but it is important to let the reader of this chapter know that at the core of our events are the attendees and everything their participation consist on: the knowledge they exchange, the dialogue they create and the networking opportunities they build.

In terms of geographical representation, we first thought that a deeper dialogue about the implementation of Open Science is mostly needed in Central and Eastern Europe. We were wrong (maybe biased?). Figure 2 shows the distribution of our events, as it was requested by institutions in various European countries. Today, we mostly receive requests from Western and Northern Europe which suggests the hot spot for Open Science in Europe. We are convinced that Europe needs to move together in this transformative journey of research and our ambition is to support all interested communities. We would very much like to see that no stone remains unturned in the process of understanding how to best achieve the needed transparency in research, no matter where these stones are, in terms of geographies or research disciplines. 


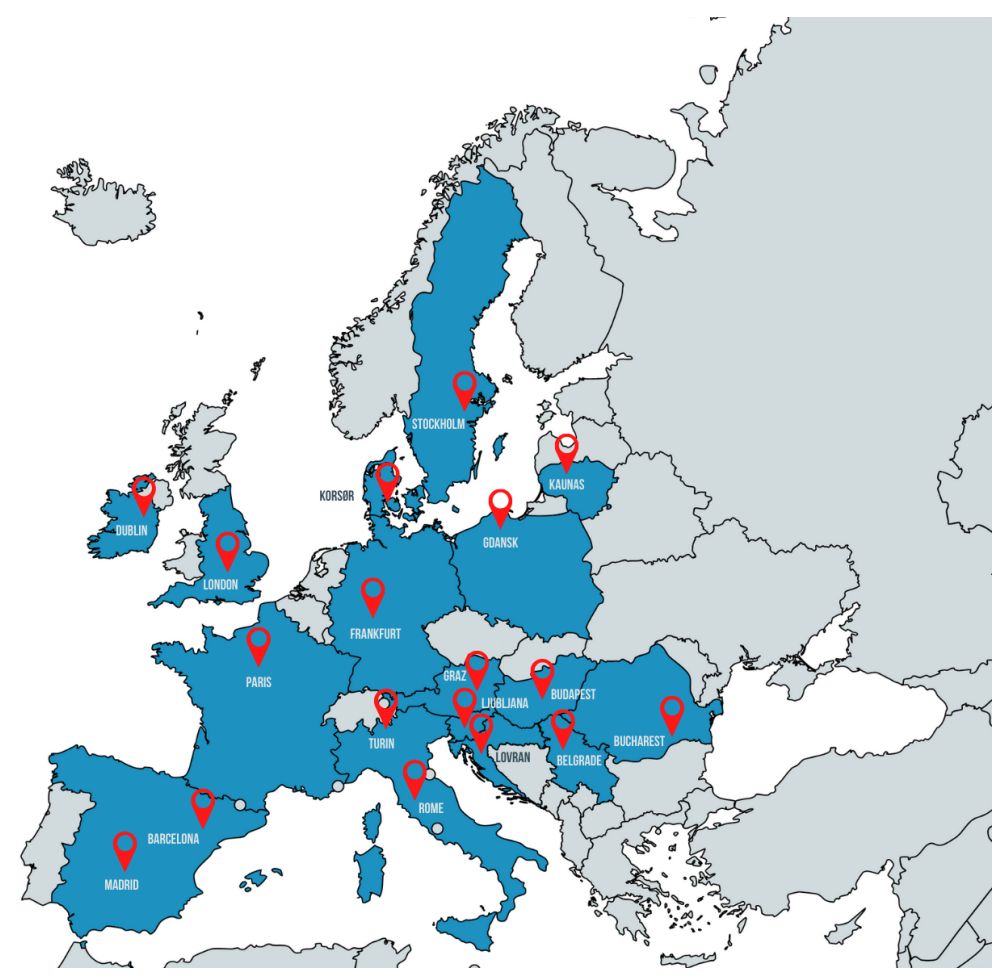

Figure 2. The Geographical distribution of Focus on Open Science chapters between 2015-2021. Updated: August 2021

All our events (or "chapters", as we call them) are organised with a local partner which gives also a member of the steering committee for that chapter. In Hungary, the traditional partner of the Focus on Open Science series was the Electronic Information Service National Programme (EIS) ${ }^{17}$ hosted by the Library and Information Centre of the Hungarian Academy of Sciences. This collaboration made it possible to organise 4 events, between 2016-2019, a series which was interrupted only by the COVID-19 pandemic. Each of the events gathered around 120 participants from all over Hungary and from abroad. The quality of the programme and the proximity of other events organised by EIS right after the Focus on Open Science chapter expanded the attendance from national to international level.

17 http://eisz.mtak.hu/index.php/en/about-us3.html 
Some of the reported notes and recommendations after 4 years of Focus on Open Science in Hungary are:

1. Pan-European approaches are needed

a. For Open Science to be a success, the concept needs to be embraced in all European countries; otherwise, Europe will lose the leadership role that it currently enjoys.

b. Hungary's reaction to Plan S firmly places its current activity in a European and even broader international context.

2. The Future

a. Open Science represented the future for scholarly activity in universities, underlining the importance of effecting a sustainable transition in an academic culture which is required to deliver success.

b. The timescale required to deliver this change in culture amongst all stakeholders is not short.

3. Rewards and Evaluation

a. The academic culture can only embrace Open Science if there is a consequent change in Reward and Evaluation practices. Using journal metrics alone, for example, as a surrogate for academic quality is simply not helpful.

4. Leadership

a. For Open Science to succeed, there needs to be a fundamental change in how research and education are performed, recorded, shared, published, evaluated and rewarded. This change can only take place where there is a clear pattern for leadership in Open Science in European countries.

5. Advocacy and Training

a. Open Science practice is best established at the university level where there are advocacy and training programmes to support it. Significant practice across Europe shows that such activities are successfully led by the university library - which is well placed to offer leadership in this area to all players in the Scholarly Communications arena. 
6. Self-Evaluation

a. Universities should undertake annual self-evaluation of their progress in all eight areas of Open Science, as identified by the European Commission and assess their progress in building up all eight pillars of Open Science activity.

\section{Focus on Open Science After the PANDemic OUTbreak}

Between 2015-2019, all Focus on Open Science chapters were physical events, with some online participation, mostly driven by the Budapest and Ljubljana chapters, where local organisers broadcasted the events over the internet. We gathered an overall audience of a bit more than 3000 participants.

An effect of the 2019 pandemic outbreak was for us to cancel 3 chapters in 2020: Rome, Budapest and Antalya (ANKOSLink). It was a difficult decision which motivated us to discuss further changes with the Steering Committee.

First, we revisited the mission statement and the goals of this series.

Our new mission is to contribute to building more autonomy for science and scholarship through Open Science. Research becomes ever more elitist if a small number of people decide what the worthwhile and valid projects are ${ }^{18}$. By building a bridge of trust between researchers and the public, eliminating data manipulations, paywalls to trustful knowledge, and redesigning its reward systems, Open Science is making a grand commitment to better serve the world. Open Science has the responsibility to step up and lead the effort of keeping misinformation at bay. If only for these reasons, science deserves an autonomous place

18 Molloy, J., Liboiron, M. (n.d.), We need to break science out of its ivory tower here's one way to do this. [online] The Conversation. Available at:

https://theconversation.com/we-need-to-break-science-out-of-its-ivory-towerheres-one-way-to-do-this-76354. 
in our society. Our society needs to gain the right to discover, the right to know and the right to develop new solutions that transform our world for the better. Today, such rights are not clearly guaranteed. Research is only granted and commissioned to push the frontier of our knowledge. It needs more than that: the right to do so.

As we set ourselves this new mission, our goals are to address the challenges and opportunities posed by Open Science in this new context. The major difference between what we did in the past and what we do now is the increased interaction with academic societies, NGOs, mass media as well as stronger connections with institutions and individuals that provide education and knowledge.

Second, we decided on a new format: digital by default.

We believe that this new format will help us to create more inclusive and sustainable conversations and to trigger more actions and interactions. Each community we engage with has the chance to promote the events to more participants, including those that were previously not able to travel or to allocate enough time to attend our events. The same effect will be produced for our contributors (speakers, chairs, panelists). The new format is also more environmentally friendly and eliminates unnecessary consumerism. These two topics are increasingly relevant for researchers and for the public. We don't exclude the possibility of having on-site events in the future, but we decided to set the digital model as the default model from 2021 onwards. The on-site meetings could be redesigned, to accompany the digital event, be focused on decision-makers and to trigger institutional changes.

\section{CONCLUSions AND A POSSIBLE PATH FORWARD}

On the cultural level, for Open Science to become a reality, all stakeholders should advocate for it and implement measures that bring more transparency on the research endeavours. On the executive 
side, they need to determine what should be the collaboration and the competition areas for research organisations, funders, nations and societies.

For years, research and innovation delivered the competitive edge of organisations and nations. It grew as a profession embedded in a culture of secrecy. While Open Science started with the dissemination of research output in journals and letters in the middle of the $17^{\text {th }}$ century (Denis de Sallo, Journal de Savants) it was only in the end of 80 s when researchers started to advocate more solidly for a culture of transparency, including the research data, methodologies, protocols, etc. It was only very recently that researchers started to register their reports before starting data collection and committed to publish the negative results.

The funders, the research organizations, the researchers themselves but also the private sector (a massive contributor to the $R \& D$ investment) now realize the potential of research transparency and the value of pre-competitive collaboration. Open Science represents a blueprint for all involved stakeholders and it deserves an intensive effort to be transformed in a new research culture.

Organising the Focus on Open Science series, we understood the need to pass from rhetoric to practice (for the Open Science transformation). This process is currently done in an heterogeneous way. While the funders show a high level of determination, the research organisations need to build more understanding and leadership. It requires a long term vision for research organisations to not only embrace the principles of Open Science (rhetoric), but also to support the researchers in this transformation (practice). This is a topic which we currently focus on.

By running this series across Europe, we had the opportunity to understand that the researchers remain the most vulnerable stakeholders in regards to this transformation. A reformed system of evaluation in research, including new metrics (more inclusive and 
less proxy-patterned), more support to early careers and a research infrastructure more versatile towards research data are just a few features that need to be changed to effectively deliver capacity for Open Science and further on, individual support for researchers.

We also learnt that the research community (including administration, funders and support organisations) faces an urgent need to separate hype from hope in what Open Science is expected to deliver. An example is the trend of introducing the prefix "open" to all research activities and supporting "open to everything" unconditionally. We agree that a transparent society is an ideal place to live, but society needs to meet certain requirements before being able to live in full disclosure. Take the research data. In today's world, FAIR Data ${ }^{19}$ makes much better sense than Open Data.

Not lastly, the experience of over 30 chapters of this series, built for us the perspective that Europe became a policy laboratory for transforming the research activities from secrecy to openness. This is a courageous act that comes together with responsibilities. While policies could be tested and adapted (if they are wrong), the responsibilities don't have the same luxury. Responsibilities are not tested; they are assumed. This is why we need to be very determined in Europe, for accepting the associated responsibilities of Open Science. Funders and research organisations should assure the researchers that they are prepared to take the responsibilities of such massive cultural change. That includes departing from the idea that Open Science is non-expensive and could be achieved with a handful of volunteers. Taking accountability for the full effect of Open Science transformation is equally important with promoting it or to make it happen.

A possible path forward for the Focus on Open Science series is to help encourage the leadership of research organisations in pursuing the cultural change while professionalising the needed change management programmes that are required to accelerate it.

19 https://www.go-fair.org/fair-principles/ 


\title{
Az EGYETEMI KÖNYVTÁRAK SZEREPE A NYÍLT TUDOMÁNY MOZGALOM ELTERJESZTÉSÉBEN
}

\author{
Hoczopán Szabolcs \\ Molnár Tamás
}

Az egyetemi könyvtárakban - különösen az SZTE Klebelsberg Könyvtárban - az Open Science előfutárai a szüken vett Open Access és a Szerzői Eszköztár ${ }^{1}$ oldalunkon az évek során kiépült szolgáltatásaink voltak. Közéjük tartozik például az intézményi nyílt publikációs díj támogatási rendszer², a publikálást közvetlenül támogató szolgáltatásaink (lektorálás, folyóirat-ajánló, plágiumkereső, publikációs e-learning felület és előadások, predátor folyóiratazonosítás, szerzői jogi tanácsadás), az OJS folyóirat-platformunk ${ }^{3}$, a jelenleg is épülő OMP e-könyv platformunk, DOI irodánk és zöld Open Access vonalon a publikációrepozitóriumunk.

A „keményebb” Open Science-szel a kutatási adatmenedzsment feladatai kapcsán kezdtünk el foglalkozni, RDM tanácsadás, adatkezelésiterv-konzultáció és adatrepozitórium-választásban való segítségnyújtás formájában ${ }^{4}$.

\section{Az Open Access}

Az Open Access-publikálást támogató szolgáltatások immár hat évre tekintenek vissza az SZTE Klebelsberg Könyvtárban, és egyértelműen sikertörténetnek könyvelhetők el.

1 http://szerzoknek.ek.szte.hu/ (Utolsó megtekintés: 2021. 07. 30.)

2 Krisztina Muzs, Tamás Molnár, Szabolcs Hoczopán, Open Access pályázati rendszer technikai megvalósítása és a szerzók támogatása a Szegedi Tudományegyetemen = Networkshop 2019 Konferenciakötet. https://doi.org/10.31915/NWS.2019.15

3 http://www.ek.szte.hu/ojs/(Utolsó megtekintés: 2021. 07. 30.)

4 Zeller Rozália, Hoczopán Szabolcs, NAGY Gyula, Kutatási adatkezelést támogató szolgáltatás a Szegedi Tudományegyetemen = Networkshop 2021.

https://kifu.videotorium.hu/hu/recordings/42348 
A szolgáltatások gerincét természetesen a nyílt hozzáférés publikációs költségeinek támogatása adta. Az intézményi OA-támogatás maga a könyvtárban egy központosított rendszeren keresztül valósul meg. Ez a központosítás teszi lehetővé az igények minőség alapú szelektálását ${ }^{5}$, az intézményi anyagi lehetőségekhez és szerződésekhez való igazítását, majd a kézirat útjának egyengetését a kiadói rendszerben, hogy a megfelelő adatokkal (affiliációval, előfeltételekkel, kódokkal stb.) legyenek ellátva, így a megfelelő szerződés hatálya alá kerülhessen, és az elfogadást követően ne legyen probléma az APC kiegyenlítésével. A 2020-as év során majdnem 600 elbírált OA-támogatási igényből végül 340 SZTE-publikáció született meg.

A fentiekből adódik, hogy a Könyvtár feladata a folyamatosan változó Open Access publikációs lehetőségekről tájékoztatni az Egyetemet. Erre a célra minden létező csatornát megragadunk.

Az évek során a szerzőkkel való folyamatos kapcsolattartás, a rengeteg közös munka révén alkalmunk volt pontosan felmérni, hogy a szerzőinknek milyen területeken van szükségük publikációs segítségre, és amelyeken magunk kompetensek voltunk, újonnan indított szolgáltatások keretében nyújtottunk támogatást a kutatóknak.

Ezen felül az SZTE-szerzőkkel kialakult (többnyire jó) kapcsolatainkat felhasználtuk arra is, hogy minden létező informális és hivatalos módon terjesszük az Open Science üzenetét.

\section{OA FOLYÓIRAT-AJÁNLÓ SZOLGÁLTATÁS}

Az OA publikációs források négy formáját kezeljük jelenleg az egységes szabályrendszer szerint. Ezek az egyetem által az általános OA célokra szánt (sajnos évről évre kisebb) keretet, az EISZ által megkötött

5 http://szerzoknek.ek.szte.hu/tamogatott-oa-publikalas/ (Utolsó megtekintés: 2021. 07. 30.) 
transzformatív szerződések OA kvótái ${ }^{6}$, az SZTE által kötött Read and Publish szerződések kvótái és a tisztán Open Access kiadóknál való publikálásra dedikált keret. Sajnos ezek az Open Access források a leggondosabb tervezés mellett sem tartanak ki feltétlenül egy teljes éven keresztül. A korábbi évek során mindegyik keretünk esetében volt arra példa, hogy év közben merült le a pénzösszeg vagy a publikációs kvóta ${ }^{7}$, nem csekély felháborodást keltve a szolgáltatás folyamatosságában bízó, illetve az azt jogosan el is váró kutatók közt.

Az első, a kutatókat komolyabban segítő szolgáltatásunk, az OA folyóirat-ajánló ${ }^{8}$ a fenti probléma melléktermékeként született meg. Amikor a Taylor and Francis read and publish konzorcium országosan bedőlt a kiadó nem túl korrekt árképzési módszerei miatt ${ }^{9}$, vagy amikor a Frontiers és MDPI kiadókkal való együttműködést mondtuk fel (a kiadók finanszírozhatatlan, meghívásos alapú különszám-özön publikációs stratégiájuk miatt), szükségessé vált, hogy a hoppon maradt szerzőinknek egy alternatív, maximálisan megfelelő folyóiratot tudjunk ajánlani, és ezzel tompítani az adott forrás hiányát. Meglepő módon a szükségmegoldásnak indult kezdeményezés népszerű lett a szerzőink körében, a gyakorlatban is igazolódott, hogy jók az ajánlásaink, így adta magát, hogy elszakadva a tűzoltástól, olyan szerzőknek is rendelkezésre álljunk, akik még ténylegesen bizonytalanok a folyóirat-választásban, a megfelelő scope-pal rendelkező folyóirat megtalálásában. Az alapkeresést a szolgáltatás elindításának hivatalos időpontjától kezdve, opcionális elemekkel egészítjük ki, vagyis a szerzők bármilyen kívánságát (kvartilis, IF stb.) beépítjük a keresésbe. Találati listaként a

6 Péter Süтő, Az EISZ open access szerződéseinek gyakorlati tapasztalatai = Networkshop 2020 Konferenciakötet. https://doi.org/10.31915/NWS.2020.6

7 http://eisz.mtak.hu/index.php/hu/open-access/open-access-hirek/404-oakvotak-kimerulese-a-wiley-es-az-ieee-kiadoknal.html (Utolsó megtekintés: 2021. 07. 30.)

8 http://szerzoknek.ek.szte.hu/folyoirat-ajanlo/ (Utolsó megtekintés: 2021. 07. 30.)

9 http://eisz.mtak.hu/index.php/hu/363-a-magyar-konzorcium-nemhosszabbitja-meg-a-szerzodest-a-taylor-francis-kiadoval.html

(Utolsó megtekintés: 2021. 07. 30.) 
szerző a legrelevánsabb 5-10 OA folyóiratcímet kapja meg az igényelt adatokkal kiegészítve, azon belül a legjobb cím kiválasztása már a szerző feladata.

A szolgáltatás népszerűségét mutatja, hogy folyamatosan érkeznek a keresési igények, noha sokszor az igénylők a szolgáltatás honlapját meg sem találták, de már „hallottak a könyvtár szolgáltatásáról”.

\section{Predátor Azonosító sZOlgáltatás}

Hasonlóképpen a szükség és a gyakorlat hívta életre a predátor folyóirat-azonosító szolgáltatásunkat. Az alapprobléma jól ismert. Az Open Access árnyoldala a számos parazita folyóirat, melyek tudományos értékkel nem rendelkeznek ugyan, de borsos árat szednek be a szerzőktől, akik az anyagi veszteség mellett a publikációjukat is elvesztik így. Észleljük időről időre, hogy predátor kiadók környékezik meg az egyetemet, a szerzőinket, és kérik fel egy-egy cikk megírására a szakterület „vezető” folyóiratába. A valótlan állítások meglepően sok kutatót csábítanak el. Sajnos, az új predátor folyóiratok gyarapodó száma, illetve az egyértelmű kritériumok hiánya miatt, és mert hitelesnek tekinthető predátor listákat már senki sem mer készíteni ${ }^{10}$, a kutatóknak nincs mihez nyúlniuk, ha predátor-gyanús kiadó lép velük kapcsolatba. Jó esetben az OA-publikálás ügyintézése során keletkezett ismeretség kapcsán előzetesen kérdezték meg a könyvtár munkatársait adott folyóirat besorolásáról, rossz esetben pedig a kézirat beküldése után, amikor már sok mindent nem tehettünk.

Nyilvánvalóvá vált, hogy szerzőinknek szüksége van egy olyan fix szolgáltatásra, mely kifejezetten a rosszindulatú folyóiratoktól védi okket. A szolgáltatás népszerűsítésével pedig ${ }^{11}$ az alapproblémára is fel tudtuk hívni a figyelmet.

10 Grudniewicz, A., Moher, D., Cobey, K. D., Bryson, G. L., Cukier, S., Allen, K., Ardern, C., Predatory journals: no definition, no defence, Nature, 576(7786), 2019, 210. https://doi.org/10.1038/d41586-019-03759-y

11 http://szerzoknek.ek.szte.hu/predator-folyoirat-azonositas/ (Utolsó megtekintés: 2021. 07. 30.) 


\section{A LÁthatósÁG NÖVELÉSÉNEK KÖNYVTÁRI ESZKÖZEI AZ SZTE-S PUBLIKÁCIÓK ESETÉBEN}

A kutatók a Publish or Perish szorításában néha nagyobb erőfeszítést tesznek a cikkek számbeli gyarapításáért, mint a hivatkozások számának növeléséért. Ennek természetesen a régi beidegződéseken alapuló teljesítményértékelési rendszerek az okai, azonban a mai online világban ez utóbbira is nagy figyelmet kellene fordítani a kutatói életpálya felépítése során, hiszen a generációs váltás a kutatói világot is eléri: jönnek azok a generációk, akiknek az online jelenlét egyre természetesebb ${ }^{12}$. Az online disszeminációnak, valamint az online impact mérésének is kialakult már a módszertana ${ }^{13}$, amit érdemes akár egy-egy PhD képzés tematikájába is beilleszteni.

Az SZTE Klebelsberg Könyvtára a láthatóság növeléséhez kutatói szemszögből nézve inkább passzív, mint aktív eszközökkel járul hozzá. (Természetesen folyamatos a szerzői képzés is, de ez inkább tekinthető célzottnak, egyes kutatókra irányulóknak, mint tömegesnek. A célzott képzés része az is, hogy a könyvtár részt kért a $\mathrm{PhD}$ hallgatók képzésében, melynek keretében On-line szakirodalmazás címen tart kurzust, szót ejtve benne többek között az Open Access, Open Science kérdéseiről is).

Részvételünk ${ }^{14}$ az egyetemen született publikációk disszeminációjában a következő eszközök által valósul meg jelenleg:

12 Barton, C. J., Merolli, M. A., It is time to replace publish or perish with get visible or vanish: opportunities where digital and social media can reshape knowledge translation, British Journal of Sports Medicine, 2019, 53, 594-598. https://doi.org/10.1136/ bjsports-2017-098367

13 Ross-Hellauer, T., Tennant, J. P., Banelytė, V., Gorogh, E., Luzi, D., Kraker, P. et al., Ten simple rules for innovative dissemination of research, PLoS Comput Biol 16(4): e1007704, 2020. https://doi.org/10.1371/journal.pcbi.1007704

14 KeveHÁzi Katalin, Nyílt hozzáférés a gyakorlatban, TMT, 63 (5), 193-197. 


\section{REPOZITÓRIUMOK}

Az SZTE Klebelsberg Könyvtára tudományos eredmények tárolását önálló gyűjteményeken keresztül végzi. Van repozitóriuma a doktori disszertációknak, egyetemi kiadványoknak és az SZTE-n készült publikációknak.

Az Eprints saját statisztika pluginja szerint az indulás óta közel kétmillió letöltésnél jár a Publicatio repozitórium esetében, a népszerű letöltések közé a DOI-val nem rendelkező, főleg magyar nyelvű anyagok tartoznak.

Mindhárom repozitórium minősítve van, s a minősítésnek köszönhetően már részben fel lettek készítve későbbi láthatósági céljaink eléréséhez. Ehhez az MTA-KIK-ben működő Repozitórium Minősítő Bizottság ${ }^{15}$ iránymutatásait kellett a gyakorlatba átültetnünk. Ennek megfelelően kezdődött el repozitóriumaink következő adatbázisokban való regisztrációja: BASE, OpenDOAR, ROAR.

Az alábbi adatbázisban történt regisztrációk nagy segítségünkre voltak a repozitált tudományos eredmények terjesztésében:

\section{BASE}

$\mathrm{Az}$ egyik leghasznosabb lépés volt a $\mathrm{BASE} \mathrm{E}^{16}$-be történő regisztráció. $\mathrm{Ez}$ egy igen nagy lefedettséggel rendelkező keresőmotor (2021 szeptemberében 272406165 dokumentumot tartalmaz 9100 tartalomszolgáltatótól). A jelentősége nem is csupán a nagyságában rejlik, hanem abban, hogy ő maga is tovább szolgáltatja a metaadatokat más adatbázisok számára. Hogy melyeknek, azt sajnos kérésre nem árulták el, de kiterjedt kapcsolatainknak köszönhetően az évek során kiderült néhány hely, ahol a BASE-ből veszik az adatokat. Csak felsorolásképpen: Zotero (külön plugin segítségével), EBSCO Discovery Service.

15 Ma már Repozitóriumminősítő Szakbizottság.

16 https://www.base-search.net 
A repozitóriumaink mellett ide regisztráltunk néhány OJS-ben szerkesztett folyóiratot is, hiszen az OJS is biztosít OAI-PMH kimenetet, amin keresztül a BASE-be történő aratás megvalósulhat.

\section{UNPAYWALL}

Az Unpaywall egy alulról indult kezdeményezés, mely a zöld Open Access útját hirdeti, segítségével jelenleg 29 millió dokumentum érhető el legálisan. Szolgáltat Gold OA folyóiratokból származó cikkeket, valamint a zöld OA keretében cikkek postprint és preprint formájában elérhető változatát is. Itt kell megjegyeznünk, hogy az SZTE Publicatio repozitórium csak a cikkek megjelent és postprint változatát fogadja be. Az Unpaywall csak a DOI-val rendelkező dokumentumokat tartalmazza (így 2021 augusztusában az SZTE Publicatio repozitórium 14.039 dokumentumából így 4237-et indexel), korábban oaDOI volt a szolgáltatás neve, és a ráépülő plugin volt az Unpaywall. Ma már egységesen Unpaywall néven fut ez a hasznos szolgáltatás. Forrásai a PubMed Central, a DOAJ, Crossref és a Datacite. Ők maguk is számos más szolgáltatónak továbbítják a nyílt elérésű, DOI-val rendelkező dokumentumok metaadatait. Ezek köre egyre bővül, s mivel a metaadatok XML alapú tárolása lehetővé teszi a szemantikus web alapját képező gép - gép kommunikációt, egyre több szolgáltatás épül a kimenetükre, s egyre több alapszik közülük a mesterséges intelligenciára.

\section{CORE}

E betűszó a COnnecting REpositories-ből származik. A repozitóriumok és a folyóiratok láthatóságának növelését tűzte ki célul, különböző kapcsolódások kifejlesztésével. Ilyen például a CORE Recommender plugin ${ }^{17}$, mely a világ több repozitóriumában telepítve van, és a résztvevő repozitóriumokból ajánl az adott cikk témájához hasonló, nyílt hozzáféréssel elérhető cikkeket. Jelenleg közel 212 millió dokumentumot

17 Pontika, Nancy, Anastasiou, Lucas, Charalampous, Aristotelis, Cancellieri, Matteo, Pearce, Samuel, Knoth, Petr, CORE Recommender: a plug in suggesting open access content, 2017. http://hdl.handle.net/1842/23359 
tartalmaz a világ minden tájáról. A Publicatio repozitóriumban a CORE Recommender plugin nincs telepítve, mivel a felhasználóink zöme célirányosan érkezik az általuk keresett publikáció elérésére, ezért egyelőre az elsődleges repozitóriumi cél a láthatóság növelése, a szakirodalmazás elősegítése csupán a távolabbi célok között szerepel.

\section{OPENAIRE}

Az OpenAIRE az elmúlt tíz év során igen nagy fejlődésen ment keresztül. A repozitóriumhoz fejlesztett plugin célja elsősorban az volt, hogy az EU FP7-es projektjeiből származó publikációkat arathatóvá tegyék az OpenAIRE számára, új metaadatmezők hozzáadásával OAIPMH kimeneten át. Ez a plugin lehetővé tette később a H2020-as projektek $^{18}$ és az OTKA projektek publikációs kimenetének mérését a repozitóriumon belül.

Miután az OpenAIRE lehetőséget biztosít repozitóriumok regisztrálására is, ezért az Egyetemi Kiadványok és a Publicatio is regisztrálva lett ide. Jelenleg, ahogy változik az OpenAIRE, s egyre inkább az Open Science minél teljesebb körű kiszolgálására törekszik, úgy lesz egyre több kapcsolódó szolgáltatása.

\section{OJS FOLYÓIRAT PLATFORM}

Az Open Journal System, online folyóirat-szerkesztő és -megjelenítő rendszer, nevével ellentétben, nem a nyílt hozzáférést szolgálja feltétlenül, csupán a szoftver maga nyílt hozzáférésű. A használata lehetőséget ad előfizetéses folyóiratok létrehozására és kezelésére is ${ }^{19}$.

18 Nyílt hozzáférés és Nyílt adat a Horizon 2020-ban Miben segíthet az OpenAIRE?, OpenAire Horizon 2020 Tájékoztatók https://openscience.hu/wpcontent/ uploads/2019/03/oa_tajekoztato_projektkoordinatoroknak_20181013_ magyar.pdf

19 Holl András, Bilicsi Erika, Nyílt publikálási szoftverek és platformok = Networkshop 2019, szerk. Tick József, KoKas Károly, Holl András, 2019. április 23-26., Széchenyi István Egyetem, Győr-Budapest, Hungarnet, 2019, 7, 54-60, https://doi.org/10.31915/NWS.2019.7 
Az SZTE Klebelsberg Könyvtárban akkor indult e rendszer kipróbálása, amikor annak 3.0-ás verziója elindult, így elkerülhetővé vált a sok problémával járó verzióváltás. A célzott felhasználók az Egyetemi Kiadványok repozitóriumának feltöltésekor megismert működő szerkesztőségek voltak. E folyóiratok többsége itt-ott, tanszéki honlapokon létezett, némelyik a Google által sem volt könnyen megtalálható. Többnyire mindössze 100-150 példány nyomtatott szám állt belőlük rendelkezésre (a nyomdai költségek miatt), és azok terjesztése is elég esetleges volt.

A szerkesztőségek beköltözését eleinte egy belső pályázat segítségével, később a pozitív példákon keresztül motiváltuk. Felismerték, hogy a korábbi, e-maileken történő szerkesztési folyamat felváltása egy komplett szerkesztőségi keretrendszerrel, milyen előnyökkel jár.

Jelenleg a tanszékek tisztában vannak azzal, hogy akár a folyóiratalapítás is könnyebben megy akkor, ha ezt a rendszert használják.

A könyvtár vállalta, hogy segít a felkészülésben, abban, hogy az adott folyóiratot a későbbiekben a Scopus, illetve a Web of Science befogadja. Ezek elég nagy célok egy-egy egyetemi folyóirat számára, de lesznek olyanok, akik elérhetik ezt.

Az egyetemi könyvtár a DOI-számok regisztrációjával, a Scopus, WoS követelmények ismertetésével, és gyakran az idejétmúlt formák naprakésszé tételében tud segíteni.

Az SZTE Klebelsberg Könyvtár figyelemmel kíséri az MTA-KIKben működő folyóiratminősítő bizottság kezdeményezéseit is, és ezekről folyamatosan konzultál a szerkesztőségekkel is. Tudatosítani kellett bennük például, hogy léteznek állandó azonosítók, melyeket használtatni kell a szerkesztőségi folyamat során (ORCID, DOI). Vannak tudományterületek, ahol a források és a hivatkozások közötti differenciálásra kellett felhívni a figyelmet. Számos esetben kellett rámutatni arra, hogy az online felületen lévő cikkek, PDF fájlok önálló 
életre kelhetnek, ezért az egyes cikkeken mindig fel kell tüntetni azt, hogy honnan „származnak”.

Munkánk eredményeként 21 folyóirat-szerkesztőség dolgozik már aktívan OJS platformunkon, és legalább 4 szerkesztőséggel zajlanak már a beköltözési elókészítő munkálatok. Apró, de inspiráló sikernek tekintjük, hogy a platformon való megjelenést követően folyóirataink nagy részéért már sorban álltak az adatbázis aggregátor cégek, a ProQuest és az EBSCO. Tematikus adatbázisaikban való megjelentetéssel is folyóirataink láthatóságát segítették elő.

Sajnos, az OJS nagy hátránya az, hogy kevés a testreszabhatósági lehetősége, viszonylag ritkák a hozzá írott pluginok, és néha úgy tűnik, hogy a fejlesztők távol tartják magukat a korszerủ folyóirat-működtetési normáktól, azaz az igényeket távolról követik csak. Így fordulhat az elő, hogy a láthatóságról nem lehet teljes képet alkotni.

\section{DOI}

A Digital Object Identifier önmagában nem járul hozzá egy-egy cikk idézettségéhez, noha vannak arra utaló jelek, hogy néhány kutató ezt reméli ennek használatától.

Ez csupán egy technikai eszköz, mely nem tükrözi az adott digitális objektum minőségét. ${ }^{20}$ Tény, hogy a DOI által használt metaadat séma, mely elvileg egy teljes bibliográfiai leírást tartalmaz a dokumentumról vagy adatról, viszonylag megengedő, azonban minél teljesebb a leírás, annál jobb helyezést lehet elérni az adatbázisokban vagy például a CORE típusú ajánlórendszerekben.

Az SZTE Klebelsberg Könyvtárában a DOI-igénylés a Crosref felé feltöltött XML segítségével történik, ügyelve arra, hogy az a hivatkozásjegyzéket és a támogatási adatokat is tartalmazza.

20 Bilicsi Erika, Hazai folyóiratok minősitése a Magyar Tudományos Müvek Tára alapján, Belügyi Szemle, 69(5), 2021, 723-733. https://doi.org/10.38146/BSZ.2021.5.1 
(Az OJS DOI pluginja, sajnos, hibás, nem jön ki minden adat, mely a rendszerben szerepel, illetve vannak hiányos adatok is, így az ottani kimenet mindenképpen korrekcióra szorul.)

Az SZTE Klebelsberg Könyvtára mindig is elkötelezett marad, és minden segítséget megad a szerzőknek, publikációik, s remélhetőleg hamarosan kutatási adataik láthatóságának növelése érdekében. Ennek a célnak az elérése érdekében segíti az egyetemen működő szerkesztőségeket is a minél jobb és egységesebb folyóirat-szerkesztési gyakorlat kialakításában, bízván abban, hogy hamarosan minél több „Scopus-kész" nyílt hozzáférésű folyóirattal fog az egyetem rendelkezni.

\section{Open Science és RDM KéRdőív}

2020. év végén, a Debreceni Egyetemi Könyvtár mintáját követve egy átfogó kérdőívet állítottunk össze, hogy felmérjük az SZTE kutatóinak elvárásait és igényeit az Open Science és különösképpen a kutatási adatkezelés terén ${ }^{21}$. A kérdőívre meglepően sok válasz érkezett, ami önmagában is jó jelnek számított, hiszen mutatta, hogy a kutatóinkat foglalkoztatja a téma.

A kérdőív válaszait kiértékeltük ${ }^{22}$, és a továbbiakban azok alapján igyekszünk meghatározni, milyen irányba is kellene folytatnunk a munkát az Open Science területén. A jelzett igények alapján több szolgáltatást, némi önképzést követően, már el tudtunk indítani 2021 elején ${ }^{23}$, más igényelt szolgáltatások, mint például az intézményi adatrepozitórium megépítése, még váratni fog magára, hiszen túl van jelenlegi lehetőségeinken.

21 Zeller Rozália, Hoczopán Szabolcs, NAGy Gyula, Kutatási adatkezelést támogató szolgáltatások elókészítése a Szegedi Tudományegyetemen kérdőív és válaszok [Data set], Zenodo, 2021. https://doi.org/10.5281/zenodo.5166625

22 Zeller Rozália, Hoczopán Szabolcs, Nagy Gyula, Kutatási adatkezelést támogató szolgáltatások elókészitése a Szegedi Tudományegyetemen, Tudományos Műszaki Tájékoztatás, 68. évf. 7. sz. (megjelenés alatt)

23 http://szerzoknek.ek.szte.hu/szolgaltatasaink Utolsó megtekintés: 2021. 07. 30. 


\section{ELINDÍTOTT KUTATÁSI ADATKEZELÉSI SZOLGÁLTATÁSOK}

\section{AdatrepozitóRIUm-AjÁnló}

Az Adatrepozitórium-ajánló volt a legkézenfekvőbb szolgáltatás, amelyet el szerettünk volna indítani az RDM kapcsán. Az Open Science-ben a publikációkhoz kapcsolódó, azokat alátámasztó adatcsomagok repozitálása amellett, hogy egyre inkább pályázati, kiadói elvárás, a láthatóság növelése miatt a kutatóknak is érdeke, hiszen a publikáció és a dataset is idézhető a kiadott DOI-k révén. Ráadásul a két objektumazonosító össze van kötve, ennek köszönhetően pedig az adatcsomagra érkező hivatkozás számít a publikációnál is, és természetesen ugyanez érvényes fordítva is.

A legmegfelelőbb adatrepozitórium megtalálása mégsem triviális a szerzők számára, akik nehezen barátkoznak meg a feladattal. De jelenleg még az adatrepozitórium infrastruktúra is éppen csak épülőfélben van, így bizonyos tudományterületek nincsenek megfelelően ellátva repozitóriumokkal. Az intézményi adatrepozitóriumok pedig ugyancsak tervezőasztalon vannak még Magyarországon, így azokra sem támaszkodhatunk.

Mindezeket figyelembe véve, elsősorban a legmeghatározóbb pályázati, fenntartói és kiadói ajánlások alapján próbálunk repozitóriumot ajánlani a kutatónak. Ha ezek nem adnak semmilyen támpontot, a DataCite DOI-szolgáltató ügynökség által összeállított Re3Data repozitóriumkereső ${ }^{24}$ segítségével folytatjuk a keresést, ahol a szűkítő facetták révén juthatunk el a kívánt találatokhoz. Ha esetleg nem találunk megfelelő diszciplináris repozitóriumot, akkor egy megbízható és minden igényt kielégítő multidiszciplináris adatrepozitóriumot javaslunk, mint például a Zenodo vagy a Figshare.

24 Registry of Research Data Repositories. Utolsó megtekintés: 2021. 05. 30. https://www.re3data.org 


\section{KutATÁSI ADATMENEDZSMENT TANÁCSADÁS}

Mivel a tudatos kutatási adatmenedzsment még viszonylag friss téma a magyarországi kutatói körökben, a szolgáltatás keretében általános kutatási adatkezeléssel kapcsolatban kívánunk segítséget nyújtani az SZTE kutatóinak. A szolgáltatást konzultációs jelleggel terveztük, hiszen nem minden esetben adhatók egyszerű, pár soros válaszok.

A kutatónak és a könyvtárosnak mindenképpen közösen kell megtalálnia az RDM kérdésekre a megoldást. A kutató ismeri saját tudományterületének specifikus adattípusait, munkafolyamatait és mérőműszereit. A könyvtáros pedig a konzultáció során a fenti információk birtokában segítséget tud nyújtani a kutatónak a kutatási adatok rendszerezésében, optimalizálásában, a metaadatok és kutatási dokumentáció létrehozásában, a kutatási adatok FAIR alapelveknek való megfeleltetésében, valamint a biztonságos adattárolási módok kialakításában.

\section{Adatkezelési TeRV KONZultáció}

A szolgáltatás keretében a pályázatokhoz kötelezően benyújtandó adatkezelési tervek kitöltésében kívánunk segítséget nyújtani a kutatóinknak. Kezdettől fogva lendületet adott a szolgáltatásnak, hogy meghirdetése környékén volt esedékes az OTKA és az Élvonal pályázatok benyújtása, melyeknek 2021-től már kötelező eleme lett az adatkezelési terv készítése. Csatlakoztunk az NKFIH-EKK-HUNOR tíz + tíz alkalmas meetup sorozatához ${ }^{25}$, melynek során az adatkezelési terv kitöltéséhez szükséges elméleti és gyakorlati tudást próbáltuk átadni az OTKA és Élvonal pályázatok kitöltőinek. A meetup sorozat jó alkalom volt számunkra, hogy sokféle tudományterület változatos adatkezelési problémáival találkozhassunk, és így saját ismereteinket is bővíthessük, miközben a konkrét feladat kapcsán az Open Science minden lényeges pontját érinteni tudtuk az előadások során.

25 Kutatási adatkezelés meetupok - NKFIH-EKK-HUNOR szervezésében. https://ekk. org.hu/2021/06/28/a-felsooktatasi-konyvtarakban-a-kutatasi-adatkezelesrolis-szol-a-2021-es-ev/ (Utolsó megtekintés: 2021. 07. 30.) 
Az első tíz alkalmas sorozatról számos SZTE-s kutató lemaradt az alkalmazott létszámkorlát miatt, ezért - átvéve a debreceni kollégák kidolgozott előadásmenetét - az OTKA pályázatok beadási határideje előtt immár saját szervezésben indítottunk létszámkorlát nélküli online találkozókat, kifejezetten a Szegedi Tudományegyetem számára. Amellett, hogy ilyen módon sikerült konzultációs lehetőséget biztosítani minden érdeklődőnek, jó alkalom volt ez, hogy a könyvtár új szolgáltatását éles körülmények között is bemutassuk az egyetemnek, valamint immár új funkciónkban is megmutathassuk magunkat.

A saját szervezésű meetupokat követően folyamatosan érkeztek a megkeresések a kutatók részéről a véglegesnek szánt DMP-k ${ }^{26}$ utolsó ellenőrzésére, valamint a még kérdéses pontok tisztázására.

Az OTKA - Élvonal pályázatok, a maguk még nem túlzottan összetett adatkezelési terveivel ${ }^{27}$, számunkra is ideális gyakorlási, betanulási lehetőséget biztosítottak. Nagy öröm volt, amikor az NKFIH pályázatokon túl, az első Horizon és FP7 adatkezelési tervekkel is megkerestek minket SZTE-s kutatók, és azt tapasztalhattuk, hogy az európai uniós pályázatok esetén is releváns segítséget tudunk nyújtani.

\section{EsZKÖZTÁR - OS KOMMUNIKÁCIÓs CSATORNÁK}

Minden lehetőséget megadunk kutatóinknak a kollégáinkkal való kapcsolat felvételére. Szolgáltatásainkhoz egyedi, beszédes e-mail-cím tartozik, melyek mögött pedig legalább három-három képzett kolléga várja a megkereséseket.

A Szerzői Eszköztár honlapunk saját hírfolyammal rendelkezik, ahol minden szolgáltatásváltozásról tudósítunk, mely a publikációs támogatásra pályázó szerzőknek óhatatlanul is szembeötlik. Ettől

26 Data Management Plan

27 Kutatásiadat-kezelési terv „OTKA” K_2l, FK_21, PD_21, ANN_21, SNN_2l pályázatok benyújtásához. https://nkfih.gov.hu/palyazoknak/nkfialap/kutatasi-temapalyazat-k2l/palyazati-csomag/kutatasiadat-kezelesi-tervk2l-fk2l-pd2l-ann2l-snn21 (Utolsó megtekintés: 2021. 07. 30.) 
függetlenül az oldalnak saját tematikus Facebook csoportja is van, szerencsére szép számú követővel, ahol minden ilyen jellegű hírt tükröztetni tudunk. A Könyvtár által üzemeltetett szakreferensi hálózat és PR-csoport is segítségünkre van a hírek terjesztésében, hiszen olyan levelezési listákhoz és kari hírlevelekhez van hozzáférésük, melyek még több potenciális felhasználóhoz tudják eljuttatni az OA-val, 2021-től pedig már a szélesebb körü Open Science-szel kapcsolatos információinkat.

Az Eszköztár honlap rendelkezik egy központi kapcsolati űrlappal is, azok számára, akik nem jutnak el a szolgáltatások weblapjaihoz, vagy esetleg nem is tudják, hogy problémájuk milyen szolgáltatáshoz tartozik. Ennek megfelelően ezen az ürlapon az összes téma felelőse rajta van, a válaszadás pedig az előre maghatározott rend szerinti.

2021 tavaszán a SZTE Klebelsberg Könyvtár fö honlapján ${ }^{28}$ már használatban lévő chat alkalmazás verzióját frissítettük fel, majd a Szerzői Eszköztár honlapunkon is bevezettük öt különböző témakörben, amelyek gyakorlatilag lefedik a teljes szolgáltatási portfóliónkat. Természetesen ez esetben is megszerveztük, hogy a chat könyvtári oldalán a specialistáink üljenek, ámbár a folyamatos ügyelet megszervezése, öt különböző speciális témában párhuzamosan, mármár a lehetőségeink határán túl van.

Elsődleges célunk a chatszolgáltatással a kutatókkal való kommunikáció felélénkítése és közvetlenebbé tétele volt. Be kell ugyanakkor látni, hogy ennek a tájékoztatási „műfajnak” is megvannak a maga korlátai. Az érintett témakörök gyakran pontos, személyre szabott útmutatásokat, több körös konzultációt igényelnek, melyre más csatornák sokszor alkalmasabbnak tűnnek. Ebben a formában a chat leginkább „forgalomirányító” funkciót tölthet majd be.

28 www.ek.szte.hu 


\section{ÖsszeFOGLALÁs}

Eddig elért eredményeink talán magukért beszélnek; az egyetemi könyvtárak nyilvánvalóan lehetnek az Open Science zászlóshajói, és azoknakiskelllenniük.Ámehhezazútönképzésekkel,próbálkozásokkal, igényfelmérésekkel és megvalósított szolgáltatásokkal van kikövezve, vállalva az új vizeken való navigálás veszélyeit, majd leszűrve a tanulságokat. Mindenképpen szükség van olyan szakmai szervezetek segítségére, mint a HUNOR, illetve egymás támogatására. Nagyon fontos lenne ezen felül (és ezen a területen az SZTE-n rengeteg teendőnk van még) a szoros együttműködés az anyaintézmény kutatásért felelős egységeivel és döntéshozóival, mert enélkül nehezen tudunk kitörni saját, könyvtáros berkeinkből.

Azt továbbra is látni kell, hogy a fentebb felsorolt feladatok egyike sem hullott csak úgy a Könyvtár ölébe. Mindegyiket önerőből indítottuk, keresve az utunkat az új Open Science világban, de egyik sem olyan, amit az egyetem más egységei ne tudnának ellátni, ha a Könyvtár esetleg nem megfelelően teljesítene az adott területen. 


\section{Az MTA KIK GYAKORLATA A NYÍlT TUDOMÁNY TÁMOGATÁSÁBAN}

Holl ANDRÁS

A tudományos kommunikáció területén a "nyílt” jelzőt először a „hozzáférés” gyakorlatának reformját felvetve használták (Budapest Open Access Initiative, Bánhegyi 2003), az MTA Könyvtár és Információs Központban (MTA KIK) is a nyílt hozzáférés volt az első támogatott terület. Ahogy előtérbe került a tudományos publikálási modell átalakításának általános igénye, létrejött a több területet átfogó nyílt tudomány koncepció. A tudományos szakkönyvtárak hamar felfigyeltek az új gondolkodásmódra, ám részben az újdonság, részben a könyvtári kompetenciákon túlmutató feladatok miatt működési gyakorlatuk még mindig a nyílt hozzáférésre összpontosít. Az MTA KIK is tájékozódik a nyílt tudomány több részterületén, azonban komoly eredményei csak a nyílt hozzáférés támogatásában mutathatóak fel.

\section{NyíLT HOZZÁFÉRÉS}

Az első PROJEKT: A REAL

Az MTA KIK nyílt hozzáféréssel kapcsolatos első projektje a REAL repozitórium (REpository of the Academy's Library) létesítése volt. Az OTKA - miután aláírta a Berlini Deklarációt - 2008-ban támogatást adott az MTA KIK-nek egy nyílt hozzáférést biztosító repozitórium felállítására. Az előkészítő munkák 2008 második félévében indultak, a repozitórium 2009-ben kezdte meg működését.

A REAL mára sok gyüjteményből ${ }^{1}$ álló repozitóriummá bővült, mely különböző jellegű digitális dokumentumokat tartalmaz, nagy részben szabadon hozzáférhetően, és mindenképpen azzal a céllal,

1 Az egyes gyüjteményeket lásd

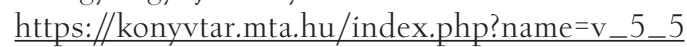


hogy az esetlegesen zárolt dokumentumok is előbb-utóbb szabadon olvashatóvá váljanak. A BOAI óta vitás kérdés a „szabad” és a „nyílt” különbsége. A REAL ebben a tekintetben is pragmatikus álláspontot valósít meg: a szabadon olvasható dokumentumok legalábbis a „gratis OA" feltételekkel használhatóak. Ahol a jogtulajdonosok Creative Commons licencet biztosítanak, ott teljesülnek a „libre OA” feltételei.

A REAL megjelenik a szervezeti és működési szabályzatban a könyvtár alapfeladatai között. Működését a Szakinformatikai Osztály szervezi, tartalmi statisztikái szerepelnek a könyvtár éves jelentéseiben.

\section{DigitalizÁLÁs}

2014 és 2019 között az MTA KIK az Arcanum Kft-vel együttműködve digitalizálási projektet folytatott, melynek keretében az MTA-hoz köthető kiadványokat, illetve az MTA KIKállományában lévő anyagokat digitalizáltunk (Holl et al. 2019). A 2019 végére elkészült kötetekkel együtt 4.8 millió oldalnyi digitalizált anyag jött létre ebben a projektben. Bár a nyílt hozzáférésről általában felmenő rendszerben gondolkodnak, az Akadémia által kiadott folyóiratoknál ebben a projektben ez visszamenőlegesen is megvalósult.

Az Arcanum-mal és az Akadémiai Kiadóval együttműködve megtörtént a kiadó által megjelentetett könyvek jelentős részének digitalizációja is, de ezek a kötetek egyelőre csak az Arcanum Szaktárs rendszerében, előfizetéssel érhetőek el. Célunk, hogy az anyag a REAL-EOD-ben szabadon is hozzáférhetővé váljon. Kisebb projektekben további digitalizálások készültek külső partnerekkel: elsősorban tudományos folyóiratok kiadóival vettük fel a kapcsolatot és engedélyükkel olyan lapok kerülhettek a REAL gyüjteményébe, mint az Orvosi Hetilap, a Közlekedéstudományi Szemle vagy a Bányászati és Kohászati Lapok.

A könyvtár mikrofilm és fotó részlege mára digitalizáló műhellyé alakult és az évek során több könyvdigitalizáló berendezést sikerült beszereznünk. Többnyire saját kivitelezésben készül a 
különgyűjtemények unikális dokumentumainak digitalizálása, a mikrofilm-gyüjtemény szelektív feldolgozása viszont inkább külső cégek segítségével.

Működési alapelvként fogadtuk el, hogy olvasói igényre történő teljes dokumentum másolás helyett lehetőség szerint digitalizálni kell és a keletkezett dokumentumot elhelyezni a repozitóriumban. MTA doktori disszertáció másolásnál az olvasónak engedélyt kell beszereznie a szerzőtől - amennyiben ez magában foglalja a digitalizálási és közreadási engedélyt is, a szkennelést ingyen végezzük el.

\section{KIADÓK SZÁMÁRA NYÚJTOTT SZOLGÁLTATÁSOK}

2014 óta segíti a könyvtár a hazai nonprofit kiadóknál megjelenő publikációk DOI azonosítóval való ellátását. Két ügynökség szolgáltatása is elérhető: a CrossRef a tudományos folyóiratok és könyvek, a DataCite a szürke irodalom és a kutatási adatok számára megfelelő portfóliót alakított ki. A DOI Iroda három munkatársa jelenleg több mint 300 partner munkáját segíti.

2016-ban a nonprofit kiadóknál megjelenő nyílt hozzáférésű, tudományos folyóiratok online megjelenésének támogatása érdekében Open Journal Systems (OJS) rendszert telepítettünk. A szoftver menedzseli a szerkesztőségek munkáját a kézirat beküldésétől a lektoráláson át az online publikálásig, weboldalt biztosít a szerkesztőségeknek és lehetővé teszi az automatikus adatcserét is más rendszerekkel. Jelenleg 37 partner veszi igénybe a szolgáltatást. Kipróbáltuk a Open Conference System (OCS) rendszert is, ami ugyanezt a szolgáltatást nyújtja konferenciakötetek publikálásához. Egy partner jelenleg is használja, de mivel a gyártó 2014 óta nem adott ki frissítést a szoftverhez, széles körben nem terjedt el, hiszen fenntartása bizonytalanná vált.

Tájékoztató weboldalt is üzemeltetünk 2015 óta, mely az openaccess.mtak.hu címen érhető el. A könyvtár ezen a honlapon nyújt információkat a fenti szolgáltatásokról, nyílt hozzáférést támogató projektjeiről és rendezvényeiről is. 


\section{KeRESŐ RENDSZEREK}

A könyvtár által szervezett egyik első kereső rendszer a hazai repozitóriumi közös kereső volt. Az MTA KIK 2014-ben megrendelte a SZTAKI-tól a korábbi, NDA@SZTAKI kereső-felület átalakítását hazai repozitóriumi közös keresővé. Ez a kereső (http://oaikereso. sztaki.hu) az MTMT Repozitóriumminősítő Szakbizottsága által minősített gyüjteményeket fogja össze. Később újabb „füleken” a hazai OJS folyóiratok (és egyetlen OCS rendszer) közös kereshetősége is létrejött, majd az egyéb, OAI-PMH protokoll segítségével szüretelhető gyüjtemények is bekerültek egy harmadik fülre.

A könyvtár egyablakos keresője² (discovery system) az Ex Libris Primo rendszere. A Primo keres a könyvtár katalógusában, repozitóriumaiban, valamint a központi listában (Central Discovery Index, CDI) kijelölt nyílt hozzáférésű tartalmakban, illetve úgy is szolgáltat teljes szöveges találatokat, hogy az OPAC-ban linkkel rendelkező tételeket is megmutatja.

Az MTA KIK folyamatosan erőfeszítéseket tesz arra, hogy elősegítse repozitóriumi tartalmainak megjelenését nemzetközi keresőrendszerekben, mint a BASE, a Jisc Core vagy a DART-Europe.

\section{Magyar Tudományos Müvek TÁra (MTMT)}

Az MTMT létrejötte (2008) után a REAL fokozatosan átvette az alapértelmezett háttér repozitórium szerepét. AKöztestületi Publikációs Adattár (KPA) által korábban biztosított teljes szöveg feltöltési lehetőség keretében összegyűlt dokumentumok közül a repozitóriumba helyezhetőeket átvittük a REAL-ba, majd megvalósítottuk az MTMTből kezdeményezhető teljes szöveg feltöltést a repozitóriumba SWORD protokoll segítségével. Az MTMT nem csak a REAL azonosítókat, hanem más zöld vagy arany OA elérhetőséget is rögzít és jelöl. Ezzel egyrészt tájékoztatja az olvasókat a szakirodalom elérhetőségéről,

2 Elérhető: http://metak.mtak.hu/ 
másrészt lehetővé teszi a hazai publikációk nyílt hozzáférési arányát bemutató statisztikák összeállítását. Az MTMTl szoftverben a SIM4RDM projekt támogatásával valósítottuk meg az Open Access statisztikákat. Ezek segítséget adhattak a nyílt hozzáférést előíró intézményi rendelkezések hatékonyság-vizsgálatához. Az MTMT2 nyilvános felülete új lehetőségeket nyitott az OA tartalmak láthatóbbá tételéhez.

Rögzíthetőek az MTMT-ben a nyilvánossá tett, archivált kutatási adatok is, a rájuk kapott hivatkozásokkal együtt, a statisztikák pedig megjelennek az összefoglaló táblázatban.

\section{REPOZITÓRIUM MINŐSÍTÉS}

2012-ben indult a publikációs repozitóriumok hazai minősítését célzó munka az MTMT keretében (Holl et al., 2012). A hazai minősítés célja, hogy megbízható, egységesen működő háttértárak álljanak az MTMT mögött, ami megalapozza a teljes szöveggel elérhető nemzeti tudományos bibliográfia építését. Mára 30 gyűjteményt minősített a szakbizottság, melyek így jogosulttá váltak az MTMT-ben egyedi külső azonosító és az automatizált feltöltés használatára, valamint a repozitóriumi közös keresőben is szerepelnek. 2020-ban hazai folyóiratok minősítésével is foglalkozni kezdett a bizottság és folyamatban van a kutatási adat repozitóriumok minősítési protokolljának kidolgozása is.

\section{SzaBÁlYozÁs}

A nyílt hozzáférés elterjesztésében kiemelt szerepe van az ezt előíró rendelkezéseknek (angolul Mandate). Az MTA különböző, nyílt hozzáférést előíró határozatai az MTA KIK több-kevesebb közreműködésével jöttek létre, és nagy szerepük volt a repozitóriumban található anyagok nagy arányú nyilvánosságának elérésében. 
- $\quad$ MTA elnöki határozat

A Magyar Tudományos Akadémia elnöke 27/2012. (IX. 24.) (http://mta.hu/data/dokumentumok/hatteranyagok/ akademiai_szabalyozasok/27_2012_elnoki_hat_Open_Access5.pdf) határozatában elrendelte a tudományos közlemények elérhetővé tételét a nyílt hozzáférés (Open Access) normái szerint. A 24/2016. (VII.15.) (http://openaccess.mtak. hu/dokumentumok/mta_hatarozat_oa_2016.pdf) elnöki határozat módosította a szabályozást.

$\mathrm{A} z$ Intézethálózat elvesztése után a szabályzat átdolgozásra szorult, megújítása folyamatban van.

- Könyv- és Folyóirat-kiadó Bizottság Az MTA Könyv- és Folyóirat-kiadó Bizottsága 2014-ben határozott a nyílt hozzáférésű publikálási kötelezettség bevezetéséről: intézkedett a támogatási szerződésekben a REAL feltöltés előírásáról (könyvek esetén legfeljebb 8, folyóiratok esetén legfeljebb 2 év embargóval), egyúttal a publikációk adatainak az MTMT-ben való rögzítéséről.

- Bolyai János Kutatási Ösztöndíj

2014 szeptemberétől kezdve szerepel a pályázóknak szóló útmutatókban a REAL repozitóriumi feltöltés követelménye: „A kutatói jelentés részeként egy repozitóriumba (pl. REAL) fel kell tölteni a beszámolási időszakban megjelent műveket, cikkeket és a közlésre elfogadott műveket is. Kérjük, hogy a repozitóriumba feltöltött kéziratok elérhetőségét tüntesse fel a kutatói jelentésben."

- $\quad$ MTA Doktori Tanács 2010 óta követelmény az MTA doktori disszertációk közzététele (ez a 2009-ben létesült REAL-d gyüjteményben valósul meg). Egyúttal visszamenőleges digitalizálás is elindult az olvasók által legtöbbször igényelt dolgozatokra kiterjedően, valamint a könyvtár főigazgatója levélben kereste meg a 2010-et megelőző 
években fokozatukat megvédett kutatókat, hozzájárulásukat kérve a dolgozatuk elhelyezéséhez és nyilvánosságra hozatalához. Így ma már mintegy 1200 dolgozat érhető el a REAL-d gyüjteményében.

- $\quad$ PhD dolgozatok

A 2011. évi CCIV. törvény [felsőoktatási tv.] 53/A. § (2) intézkedik a $\mathrm{PhD}$ dolgozatok DOI azonosítóval való ellátásáról és az MTMT-n keresztül való elérhetőségéről. A REAL-PhD gyűjtemény 2013-ban jött létre árva repozitóriumként (azoknak a doktori iskoláknak a támogatására, amelyeknél az egyetem nem tart fenn repozitóriumot).

Jelenleg megállapodás alapján a REAL-PhD-ben teszik közzé a PhD disszertációkat az alábbi egyetemek:

Andrássy Gyula Budapesti Német Nyelvű Egyetem

Evangélikus Hittudományi Egyetem

Kaposvári Egyetem

Károli Gáspár Református Egyetem

Liszt Ferenc Zeneművészeti Egyetem

Országos Rabbiképző -Zsidó Egyetem

Pannon Egyetem

Pázmány Péter Katolikus Egyetem

Testnevelési Egyetem.

Az MTA KIK gondoskodott arról, hogy ezen egyetemek publikációi bekerüljenek a DART-Europe aggregációjába.

\section{MTA OA ALAP}

Az MTA 2014-től OA publikálási alappal támogatta az intézményhálózatban a nyílt hozzáférés elérését. A könyvtár a támogatási szabályok kialakításában és az egyes támogatási kérelmek támogathatóságának vizsgálatában is közreműködött. Az alap az intézethálózat elcsatolása után megszűnt. 


\section{EISZ OA}

2019-től az EISZ „Read and Publish” avagy „Transformative” megállapodásokat kötött több kiadóval, amelyek már nem csak a hozzáférés, hanem a publikálás költségeit (APC díjak) is tartalmazták. A COMPASS szolgáltatás az oaDOI adatbázis használatával lehetővé tette a cikkek repozitóriumi nyílt hozzáférésű változatainak keresését. A COMPASS+ pedig kiterjesztette az intézményi kibocsájtás OA szegmensének vizsgálatát.

Az EISZ szerződéseiről további információkat közöl Gruenpeter et al. (2021). A nyílt hozzáférés elérésének lehetőségeiről, ezen belül az EISZ szerepéről Holl (2020) cikkében olvashatunk.

\section{ÖsSzEFÜGGÉSEK}

A nyílt hozzáférés és általában a nyílt tudomány ügyének előmozdításában kulcsfontosságú az egyes tevékenységek, projektek, rendszerek egymással való összekapcsolása. Az MTA nyílt hozzáférést vagy repozitóriumi archiválást előíró rendelkezései biztosítják a REAL gyarapodását. Másfelől a kutatói feladatok megkönnyítése is növeli a feltöltési kedvet: a közlemények MTMT-ből indított REAL feltöltése a SWORD protokoll alapján ezt segíti elő. A könyvtáron belül az Aleph REAL összeköttetés segíti a könyvtárosok munkáját. A szerkesztőségi/ kiadói feltöltés (mind az MTMT-be, mind a REAL-ba) támogatására szolgál az OAIuploader program.

\section{KAPCSOLATOK}

- A nyílt tudomány művelése elképzelhetetlen az érdekelt felek, szervezetek formális együttműködése nélkül. Az MTA KIK az alábbiakban felsorolt szervezetek tagja:
COAR - Confederation of Open Access Repositories
CrossRef - Publishers International Linking Association
DataCite 
DOAJ - Directory of Open Access Journals

ORCID - Open Researcher and Contributor ID

HUNOR - Hungarian Open Access Repositories

HRDA - Hungarian node of the Research Data Alliance

\section{Publikációk}

Az MTA KIK munkatársai jelentősen hozzájárultak az Open Science hazai szakirodalmához közleményeikkel ${ }^{3}$. A könyvtár saját kiadványait a repozitóriumon keresztül szabadon hozzáférhetővé teszi (kivételes esetben korlátozással). A könyvtár közreműködésével jelenik meg 2018 óta a NETWORKSHOP konferencia kötete, a HUNGARNET Egyesület kiadványa, Creative Commons licenc szerint.

\section{Projektek, MunKacsoport tagság}

A könyvtár mindig is fontosnak tartotta a legújabb trendek megismerését és azok implementálását saját és a hazai közösség munkafolyamataiba. Ennek érdekében számos nemzetközi projektben veszünk részt, melyeknek támogatásai segítik e cél elérését. Ilyen volt a SIM4RDM (Support Infrastructure Models for Research Data Management) ${ }^{4}$, melynek támogatásával 2014 során megvalósulhatott az OA statisztika az MTMT-ben. 2014 és 2016 között a PASTEUR4OA (Open Access Policy Alignment Strategies for European Union Research) ${ }^{5}$ projekt keretében azon dolgoztunk, hogy az európai nyílt hozzáférést támogató szabályozások egységesek legyenek, ezzel megkönnyítve a nemzetközi projektekben résztvevő kutatók publikálását és az Európai Unió

3 Az MTA KIK közleményeinek listája az MTMT-ben elérhető: https://m2.mtmt.hu/gui2/?type=institutes\&mode=browse\&sel=institutes57

4 A projekt beszámolóját lásd az Európai Bizottság weboldalán: https://cordis.europa.eu/project/id/284514/reporting

5 A projekt weboldalán lásd a segédanyagokat: http://www.pasteur4oa.eu/resources 
2012-ben megjelent Open Access Ajánlásának ${ }^{6}$ megvalósulását. A hazai legnagyobb kutatástámogató, az Nemzeti Kutatási, Fejlesztési és Innovációs Hivatal (NKFIH) is tesz lépéseket a nyílt tudomány támogatására. Ennek érdekében Open Science Szakértői Bizottságot ${ }^{7}$ hozott létre, melynek 2017-2018-ban Holl András, az MTA KIK informatikai föigazgató-helyettese is tagja volt, csakúgy, mint 2021ben az NKFIH Nemzeti Open Science Tanácsadó Testületének. Főigazgató-helyettes úr 2019 óta az EOSC FAIR Working Group ${ }^{8}$ munkájában is részt vesz képviselve a hazai kutatók érdekeit a kutatási adat menedzsmentet támogató EU-s fejlesztések területén.

\section{RENDEZVÉNYEK}

Munkatársaink részt vesznek hazai és nemzetközi rendezvényeken és számos alkalommal szerveznek a könyvtárban is olyan eseményeket, melyeken lehetőség adódik a hazai könyvtárak munkafolyamatainak egységesítésére, a jó gyakorlatok, tapasztalatok megosztására. Ilyen volt 2015-ben a Kutatási adatok kezelése címü mühelykonferencia (Kovács 2018) az MTA KIK, az MTA Társadalomtudományi Kutatóközpont Kutatási Dokumentációs Központ és az MTA Számítástechnikai és Automatizálási Kutatóintézet közös szervezésében. Szintén 2015. ben a könyvtárban került sor a PASTEUR4OA projekt kelet-európai regionális konferenciájára ${ }^{9}$ (Bilicsi et al. 2016), melyen Csehország, Észtország, Horvátország, Lengyelország, Lettország, Litvánia, Magyarország, Románia, Szlovákia és Szlovénia kutatóintézeteinek és kutatásfinanszírozó szervezeteinek képviselői vettek részt. 2017-ben a nemzetközi szerző azonosító, az ORCID (Open Research and Contributor Identifier) használatának elősegítése

6 Comission Recommendation of 17 July 2012 on access to and preservation of scientific information, ld. https://eur-lex.europa.eu/legal-content/EN/TXT/ $\underline{\text { PDF/?uri=CELEX:32012H0417\&rid }=1}$

7 A bizottság weboldalát lásd https://nkfih.gov.hu/hivatalrol/open-acces/open-science-szakertoi

8 A munkacsoport weboldalát lásd https://www.eoscsecretariat.eu/working-groups/fair-working-group

9 http://www.pasteur4oa.eu/events/118\#.YUkkg7gzbIU 
érdekében az üzemeltető nonprofit szervezet munkatársai látogattak Budapestre, hogy megismertessék a hazai közösséggel az azonosító használatában rejlő lehetőségeket (Lovász 2017). Még ugyanebben az évben sikerült Budapestre hoznunk a THOR projekt csapatát is. ${ }^{10}$ A rendezvény lehetőséget teremtett arra, hogy a kutatók, könyvtárosok, szoftverfejlesztők, a kiadók munkatársai, a kutatásfinanszírozók és intézményfenntartók megismerhessék az egyedi azonosítók használatának előnyeit és a technikai fejlesztések révén kiaknázhassák az ebben rejlő lehetőségeket. Szintén 2017-ben szerveztük meg A modern folyóirat-kiadás eszközei ${ }^{11}$ címü rendezvényünket is, melyen a kiadók munkatársainak mutattuk be a tudományos publikálást támogató legmodernebb technikai eszközöket, melyek az MTA KIK szolgáltatásai között is elérhetőek. Az EISZ munkatársai az SKS-el (Scientific Knowledge Services) együttműködve 2017-ben indították útjára a Focus on Open Science című konferenciasorozatot (Lencsés 2018), mely a nyílt tudomány neves képviselőit hívja meg Budapestre évről évre, hogy a legújabb nemzetközi trendekről elsőkézből hallhassanak a hazai szakemberek. 2019-ben a mindig nagy érdeklődésre számot tartó kutatásértékelés témában is útjára indítottunk egy konferenciasorozatot Tudománymetria: barát vagy ellenség? címmel (Móring 2019) a Digitális Bölcsészet folyóirat, az ELTE Egyetemi Könyvtár és Levéltár, valamint az MTA KIK közös szervezésében. 2019 novemberében a könyvtár adott helyet a budapesti EOSC Symposium szatellit rendezvényének, a FAIR munkacsoport ülésének.

\section{NYÍLT KUTATÁSI ADATOK}

Anélkül, hogy az MTA KIK önálló adatrepozitóriumot nyitott volna, az évek során érkeztek kutatási adatok a REAL alapgyüjteménybe is. Általában a szerzők igényelték az adataik elhelyezését, esetenként DOI azonosító biztosításával.

10 A rendezvény honlapja: https://openaccess.mtak.hu/event/thor-bootcamp/

11 A rendezvény honlapja: https://openaccess.mtak.hu/event/a-modern-folyoirat-kiadas-eszkozei/ 
A könyvtári publikációs repozitóriumokba való kutatási adat archiválás korlátai és lehetőségei a következőek. A repozitóriumban megoldható a

- $\quad$ cikkekhez kapcsolódó;

- $\quad$ kevés és kisméretü;

- $\quad$ egyszerű, lehetőleg szöveges formátumú (pl. TXT, CSV, XML, JSON)

adatok tárolása.

\section{IRODALOM}

Bánhegyi 2003

Bánhegyi Zsolt, Nyilt Hozzáférés Kezdeményezés (Open Access Initiative), TMT, 2003, 50. évf., 6-7. szám, 236-249.

https://tmt.omikk.bme.hu/tmt/article/view/2016

Bilicsi et al. 2016

Bilicsi Erika, Dér Ádám, Lencsés Ákos, Az Open Acces támogatáának közép-európai gyakorlata: Nemzetközi konferencia az MTA Könyvtár és Információs Központban, Könyv, Könyvtár, Könyvtáros, 2016, 2. szám, 20-28. http://real.mtak.hu/34102/

Gruenpeter et al. 2021

Gruenpeter, N. et al., Transformative Agreements: Overview, Case Studies, and Legal Analysis.ICM, Warszawa.

https://doi.org/10.5281/zenodo.4543422

Holl et al. 2012

Holl András, Harangi Gabriella, Drótos László, Hoffmann Ádám. MTMT rendszerrel együttmüködő repozitóriumok minôsitésének ajánlásai. Repozitóriumok minősitése, Az MTA Könyvtára TÁMOP4.2.5.A-11/1-2012-0001 „A Magyar Tudományos Művek Tára (MTMT) publikációs adatbázis szolgáltatások országos kiterjesztése” című pályázatához, Ver.: 1.02 https://www.mtmt.hu/system/files/mtak_tamop_ repozitoriumok_101_v4c.pdf 
Holl et al. 2019

Holl András, Horváth Hajnalka, Bilicsi Erika, NAgy Erika, Tömöry Pál, Folyóirat- és könyvdigitalizálás az MTA Könyvtárában. Lezárult az első szakasz, Könyvtári Figyelő, 65. évf., 2019, 3. szám, 375-382.

http://real.mtak.hu/103280/

Holl 2020

Holl András, Milyen úton érjük el a tudományos közlemények nyílt hozzáférhetôségét?, Magyar Tudomány, 2020, 181. évf. 1. szám, 121-131. http://real.mtak.hu/105068/

Kovács 2018

KovÁcs László, Adatkezelés - A (kutatási) adatok kezelése a magyar tudományos és memóriaintézményekben, Magyar Tudomány, 2018, 179. évf., 7. szám, 1001-1016. https://eprints.sztaki.hu/9620/

Lencsés 2018

Lencsés Ákos, Beszámoló a Focus on Open Science konferenciáról, EKE HÍRLEVÉL, 2018, 4. szám, 31-32.

https://eke.hu/sites/default/files/eke_hirlevel_2018_4.pdf\#page=31

Lovász 2017

Lovász Dávid, Beszámoló az ORCID-workshopról, Kalauz - a PTE Egyetemi Könyvtár és Tudásközpont szolgáltatástámogató honlapja, 2017. https://kalauz.lib.pte.hu/beszamolo-az-orcid-workshoprol/

Móring 2019

Móring Tibor, Tudománymetria: barát vagy ellenség?, Könyv, könyvtár, könyvtáros, 2019, 28. évf., 12. szám, 38-46.

http://ki2.oszk.hu/3k/2020/02/tudomanymetria-barat-vagy-ellenseg/ 


\section{A KÖTETBEN SZEREPLŐ TANULMÁNYOK SZERZŐI}

GaÁlné Kalydy DóRA

A Magyar Tudományos Akadémia Könyvtár és Információs Központ általános főigazgató-helyettese, az Elektronikus Információ Nemzeti Program megbízott igazgatója, a LIBER (Ligue des Bibliothèques Européennes de Recherche) Citizen Science Working Group tagja

Hoczopán Szabolcs

A Szegedi Tudományegyetem Klebelsberg Könyvtár osztályvezetője, könyvtáros

Holl András

A Magyar Tudományos Akadémia Könyvtár és Információs Központ informatikai főigazgató-helyettese, az RDA (Research Data Alliance) magyar csoportjának (HRDA) koordinátora, az EOSC (European Open Science Cloud) FAIR WG (2019-2020) és az EOSC TF Long-Term Data Preservation csoport (2021-) tagja.

Tiberius Ignat

A Scientific Knowledge Services (SKS) igazgatója, a LIBER Citizen Science Working Group tagja, a Focus on Open Science rendezvénysorozat irányítótestületének tagja, valamint a European Citizen Science Association és a Citizen Science Association (US) tagja.

Kiss Anna

A Magyar Tudományos Akadémia Könyvtár és Információs Központ Tudománypolitikai és Tudományelemzési Osztály fiatal kutatója, az Eötvös Loránd Tudományegyetem Pedagógiai és Pszichológiai Kar doktorandusza

Molnár Tamás

A Szegedi Tudományegyetem Klebelsberg Könyvtár könyvtárosa

Soós SÁndor

A Magyar Tudományos Akadémia Könyvtár és Információs Központ Tudománypolitikai és Tudományelemzési Osztály vezetője, az Eötvös Loránd Tudományegyetem Pedagógiai és Pszichológiai Kar oktatója, egyetemi adjunktus 


\section{A Magyar Tudományos Akadémia Könyvtárának Közleményei, ÚJ SOROZAT KÖZELMÚLTBAN MEGJELENT KÖTETEI}

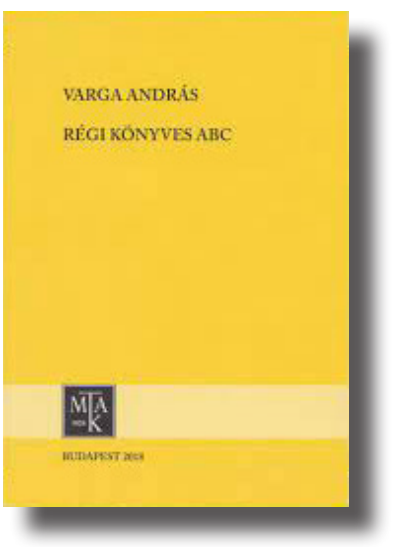

39(114) Bilicsı Erika: A MARC21 szerinti katalogizálás bevezetése az MTA Könyvtár és Információs Központban, Budapest, 2018. Budapest, 2018.
A MARC21 SZERINTI

KATALOGIZÁLÁS

BEVEZETÉSE AZ

MTA KÖNYVTÁR F́s

INFORMÁCIÓS KÖZPONTBAN

38(113) Varga András: Régi könyves ABC,

TELEKI JÓZSEF
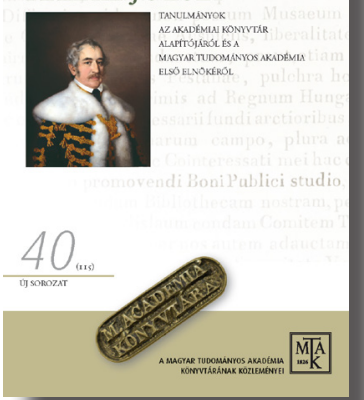

41(116) MoNoк István: Könyvtári (?) problémák, Budapest, 2020.
40(115) Teleki József. Tanulmányok az Akadémiai Könyvtár alapítójáról és a Magyar Tudományos Akadémia első elnökérôl, szerk. MoLNÁR Andrea, Budapest, 2019.

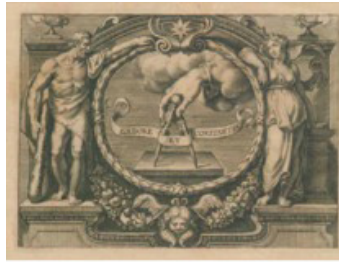

Mesos ler

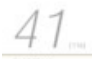




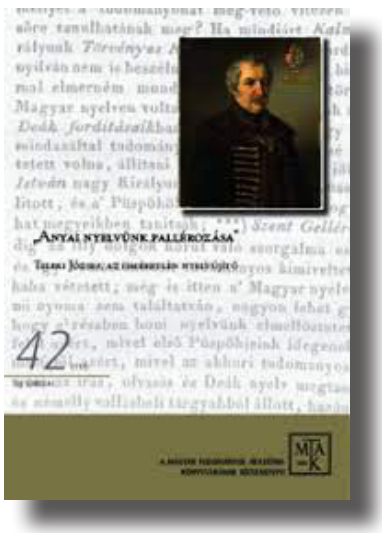

42(117) „Anyai nyelvünk pallérozása”. Teleki József, az ismeretlen nyelvújító, Péntek János és SzAвó Ádám tanulmányával, Budapest, 2020.

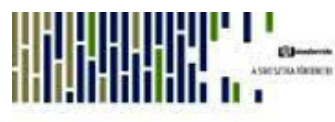

43(118) Lencsés Ákos: A statisztikai adatszabályozás módszerei a kezdetektól napjainkig Magyarországon, Budapest, 2020.

unvits ies

A statisztikai adatszabályozás módszerei a kezdetektól napjainkig Magyarországon



44(119) Presence is no island. Writings in honour of William John Mc Cormack / A jelenlét nem sziget. Irások William John Mc Cormack tiszteletére, ed./szerk. Győző Ferencz, Janina Vesztergom, Budapest, 2020. 